\title{
Site U1420
}

\author{
J.M. Jaeger, S.P.S. Gulick, L.J. LeVay, H. Asahi, H. Bahlburg, C.L. Belanger, G.B.B. Berbel, L.B. Childress, \\ E.A. Cowan, L. Drab, M. Forwick, A. Fukumura, S. Ge, S.M. Gupta, A. Kioka, \\ S. Konno, C.E. März, K.M. Matsuzaki, E.L. McClymont, A.C. Mix, C.M. Moy, J. Müller, A. Nakamura, \\ T. Ojima, K.D. Ridgway, F. Rodrigues Ribeiro, O.E. Romero, A.L. Slagle, J.S. Stoner, \\ G. St-Onge, I. Suto, M.H. Walczak, and L.L. Worthington ${ }^{2}$
}

\section{Chapter contents}

Background and objectives........... 1

Operations....................... 2

Lithostratigraphy...............

Paleontology and biostratigraphy .......6

Stratigraphic correlation............

Geochemistry .................

Physical properties .............. 10

Paleomagnetism ............... 12

Downhole logging ............. 12

Core-log-seismic integration. . . . . . . . . 14

References................. . . . . 15

Figures................... 18

Tables.................... 51

${ }^{1}$ Jaeger, J.M., Gulick, S.P.S., LeVay, L.J., Asahi, H., Bahlburg, H., Belanger, C.L., Berbel, G.B.B., Childress, L.B., Cowan, E.A., Drab, L., Forwick, M., Fukumura, A., Ge, S., Gupta, S.M., Kioka, A., Konno, S., März, C.E., Matsuzaki, K.M., McClymont, E.L., Mix, A.C., Moy, C.M., Müller, J., Nakamura, A., Ojima, T., Ridgway, K.D., Rodrigues Ribeiro, F., Romero, O.E., Slagle, A.L.,Stoner, J.S., St-Onge, G., Suto, I., Walczak, M.H., and Worthington, L.L., 2014. Site U1420. In Jaeger, J.M., Gulick, S.P.S., LeVay, L.J., and the Expedition 341 Scientists, Proc. IODP, 341: College Station, TX (Integrated Ocean Drilling Program). doi:10.2204/iodp.proc.341.106.2014

'Expedition 341 Scientists' addresses.

\section{Background and objectives}

A fundamental hypothesis to be tested with results from Expedition 341 is that the St. Elias orogen has undergone a perturbation that has markedly changed the spatial patterns and rates of deformation and exhumation in the orogenic wedge. It is proposed that enhanced glacial erosion associated with the mid-Pleistocene transition and the establishment of highly erosive ice streams leads to substantial mass redistribution in the wedge, shutting down existing regions of active deformation and refocusing the deformation and exhumation patterns of the orogen (Berger et al., 2008; Worthington et al., 2008, 2010; Chapman et al., 2008). Testing the hypothesis that the onset of ice streams with correspondingly high erosion rates has markedly altered orogenesis (Berger et al., 2008) can be accomplished by developing depositional ages and sediment accumulation rates and acquiring provenance records from near the Bering Glacier, where tectonic deformation patterns have been shown to evolve with sedimentation (Worthington et al., 2010).

Site U1420 lies within the Bering Trough (Fig. F1B), a shelf-crossing trough formed by the Bering Glacier advancing across the shelf during glacial maxima (Carlson and Bruns, 1997). The drill site penetrates through an angular unconformity at shallow subseafloor depths (180-200 m expected) that has been suggested to be the first occurrence of grounded glaciers reaching extents equivalent to the modern shelf edge (Berger et al., 2008). In highresolution seismic Line GOA2505 and coincident crustal scale Line STEEP09 (Figs. F1A, F2), a series of reflectors is imaged between the seafloor and the angular unconformity (Horizon H1). These reflectors are the signature of glacial advance-retreat cycles with a range of interpretations presented in Berger et al. (2008), Powell and Cooper (2002), Willems (2009), and Worthington et al. (2008). Seismic sequences stratigraphically above this angular unconformity were expected to represent proximal glacial deposits and many deeper sequences thought to represent shelf to slope glacimarine and paraglacial strata deposited during a time of a prograding margin with varying proximity to temperate ice. Lithofacies were expected to vary from coarse-grained diamict and conglomerate (ice proximal) to massive mud (ice-distal/withdrawn) (Fig. F3) (Powell and Cooper, 2002).

Beneath this angular unconformity (Fig. F2) are the waning folds of a portion of the Pamplona zone, which is a fold-and-thrust belt 
that has accommodated some of the tectonic shortening caused by the underthrusting of the Yakutat Terrane beneath North America to form the St. Elias orogen (Worthington et al., 2010). Previous mapping suggests that folding within the Pamplona Zone beneath the Bering Trough waned by the time of seismic Horizon H2 (Fig. F2) (Berger et al., 2008; Worthington et al., 2010). These seismic profiles also cross active faults on the slope (BT1 and BT2) and abandoned faults beneath the current shelf (BT3, BT4, and BT5) (Fig. F1). Structures BT3, BT4, and BT5 are currently buried by more than $\sim 1500 \mathrm{~ms}$ two-way traveltime (TWT) of undeformed sediments and have gradually been rendered inactive starting before deposition of Horizon 2 (Zellers, 1995; Berger et al., 2008; Worthington et al., 2008). Site U1420 is located adjacent to Structure BT4 with the goal of determining the age of cessation of deformation as indicated by the absence of growth strata above Horizon H2 (Worthington et al., 2010). Lack of significant deformation in the sequences above Horizon $\mathrm{H} 2$ indicates that the underlying faults were abandoned prior to the angular unconformity (Horizon H1), possibly because of loading by sediments (Berger et al., 2008; Worthington et al., 2010). On the forelimb of the fold associated with Fault BT5, seismic facies interpreted as a continental shelf break are present between 1.0 and $1.5 \mathrm{~s}$ TWT. This interpretation suggests that this location was a continental shelf edge prior to the formation of the angular unconformity associated with a glacial advance to near the modern shelf edge (Fig. F2). Truncations of seismic strata, the presence of growth stratal packages on the backlimb, and the overall geometry of Fault BT5 provide evidence that this structure accommodated Yakutat-North America convergence as a growth fold in addition to acting as the former shelf edge. The overall architecture of the continental margin is thus the product of coupled depositional and tectonic processes.

\section{Operations}

\section{Transit to Site U1420}

After a $30 \mathrm{nmi}$ transit from Site U1419 averaging 9.2 $\mathrm{kt}$, the vessel arrived at the fourth expedition site. The vessel stabilized over Site U1420 at 0345 h (UTC $-8 \mathrm{~h}$ ) on 14 July 2013, and the positioning beacon was deployed at $0400 \mathrm{~h}$.

\section{Hole U1420A}

After lowering the thrusters and hydrophones, the vessel switched from cruise mode to dynamic posi- tioning mode and drill floor activities began. The rotary core barrel (RCB) components for the bottomhole assembly (BHA) were assembled and run to the seafloor. The top drive was then picked up. The camera system was deployed for a seafloor survey. Following the survey, at $0850 \mathrm{~h}$ the seafloor was tagged with the bit at 248.2 meters below sea level and the camera system was pulled back to the surface. Hole U1420A was spudded at $1045 \mathrm{~h}$ on 14 July 2013. Coring continued from Core 341-U1420A-1R through Core 78R (0-749.2 m drillers depth below seafloor [DSF]) (Table T1). Because of increasing torque on the drill string, a $\sim 200 \mathrm{~m}$ wiper trip was completed, preceded by $50 \mathrm{bbl}$ of mud. Coring continued from Core 79R through Core 106R (749.2$1020.8 \mathrm{~m}$ DSF). Recovery over the entire hole was problematic because of the presence of numerous large clasts that continually jammed the core catchers and prevented core recovery. A total of 106 rotary cores were taken over a $1020.8 \mathrm{~m}$ interval, with $139.91 \mathrm{~m}$ recovered (14\%) (Fig. F4).

A total of $570 \mathrm{bbl}$ of high-viscosity mud was used for hole cleaning during coring operations. At the completion of coring, the hole was cleaned by circulating $50 \mathrm{bbl}$ of high-viscosity mud. The rotary shifting tool (RST) was run into the hole on wireline to release the bit for logging. While running in the RST, torque on the rotating drill string increased to $500 \mathrm{~A}$. The tool was pulled back and removed. After some hole remediation, another $75 \mathrm{bbl}$ sweep was pumped, and the end of pipe was pulled back to $981.2 \mathrm{~m}$ DSF. The RST tool was run into the hole again, and the bit was released in the hole at $983.6 \mathrm{~m}$ DSF. After another run of the RST to shift the mechanical bit release sleeve back into logging position, the hole was displaced with 450 bbl of $10.5 \mathrm{ppg}$ mud for logging. After displacing the hole with mud, the end of the pipe was raised up to logging depth (93.3 m DSF).

A modified logging tool string termed the Sonic-induction tool string, measuring gamma ray, borehole diameter, sonic velocity, and resistivity, was run to $288 \mathrm{~m}$ wireline log depth below seafloor (WSF). The tool string was $44 \mathrm{~m}$ long. After repeated attempts to run the tool string deeper into the hole, the string was pulled back to the BHA and another pass to 288 $\mathrm{m}$ WSF was performed. After logging up with the final pass, the tool string entered and became stuck in the BHA. The Kinley crimper was then rigged up, the crimper was deployed, and the logging cable was crimped, securing the tools in the BHA. The Kinley cutter was then deployed, and the logging cable was cut and pulled back to surface. The drill string was then pulled back to surface, the logging tools removed from the BHA, and the BHA secured. The 
thrusters and hydrophones were pulled at $0100 \mathrm{~h} 22$ July. Total time spent on Hole U1420A was 189.25 h.

\section{Lithostratigraphy}

A lithologic summary of Site U1420 is shown in Figure F5. The total depth of Hole U1420A was 1014.5 $\mathrm{m}$ core depth below seafloor (CSF-A). Recovery from 58.2 to $448.5 \mathrm{~m}$ CSF-A was $<10 \%$ but improved deeper than $448.5 \mathrm{~m}$ CSF-A, where several cores were collected with recovery between $30 \%$ and $94 \%$. Total core recovery for the entire site was $14 \%$. Additionally, numerous drilled rocks and washed clasts were recovered without a supporting matrix lithology. Cores containing mostly drilled rocks and washed clasts include 341-U1420A-10R through 47R, 49R, $52 \mathrm{R}$ through $57 \mathrm{R}, 75 \mathrm{R}$ through $79 \mathrm{R}$, and $85 \mathrm{R}$. The limited sediment recovered at Site U1420 contains seven facies. Detailed facies descriptions, information about common marine microfossils, facies occurrence in lithostratigraphic units, and tentative interpretations about depositional environments are summarized in Table T2. The dominant facies (F4f and $\mathrm{F} 4 \mathrm{e}$ ) are very dark gray $(\mathrm{N} \mathrm{3})$ to dark gray $(\mathrm{N} 4)$ clast-rich and clast-poor diamict. Photographs of the most common facies are shown in Figure F6. Based on characteristic facies associations, three lithostratigraphic units were defined (Table T3).

\section{Facies description}

Seven lithofacies were identified and are outlined in Table T2. Most of these are included within the group of facies observed at other Expedition 341 sites. Facies numbering is based on those documented for all sites, but only facies documented at Site U1420 are described here. These include massive mud with lonestones (F1a), massive mud without lonestones (F1b), clast-poor diamict (F4e), clast-rich diamict (F4f), mud with diatoms/biosilica (F5b), calcareous/carbonate-bearing mud (F5c), and volcaniclastic mud and diamict (F7).

The massive and bioturbated mud with lonestones of Facies F1a is mostly dark gray (N 4) to dark greenish gray (10Y 4/1) and has bed thicknesses that range from 3 to $300 \mathrm{~cm}$ (Table T2; Fig. F6A). Clast abundance within the mud ranges from dispersed to abundant. Bioturbation is mostly absent but occasionally slight to heavy. A diagnostic characteristic of Facies F1a is the absence or low abundance of microfossils. Lonestones consist mainly of siltstone, sandstone, and basalt (Fig. F7A-F7G). Occasional foraminifers were observed in smear slides. Facies F1b is composed of dark greenish gray (5GY $4 / 1$ or $10 \mathrm{Y} 4 / 1$ ) to very dark gray (N 3) mud, comprising 3 to $409 \mathrm{~cm}$ thick intervals (Table T2; Fig. F6B). Bioturbation is mostly moderate to heavy, and shell fragments are present. Diatoms and foraminifers are found rarely.

Facies F4e is very dark gray (N 3) to dark gray (N 4) clast-poor diamict, most often with a silty or sandy mud matrix (Fig. F6D). Beds are massive, and thickness ranges from 11 to $275 \mathrm{~cm}$. Common clast sizes are granule and pebble, with clasts being subangular to subrounded. Dominant clast lithologies are siltstone, sandstone, basalt, granitoids, argillite, rhyolite, and metasandstone. Bioturbation is absent, but some shell fragments are present. In more muddy intervals, very thin mud beds were found occasionally, as well as mud clasts and isolated sand laminae. Facies F4f is very dark gray (N 3) clast-rich diamict, typically with a muddy matrix and occasionally containing shell fragments (Table T2; Figs. F6D-F6E, F7H-F7I). Bed thickness ranges from 2 to $556 \mathrm{~cm}$. Common clast sizes and lithologies are similar to those described for Facies F4e. Two intervals with visually apparent clast orientation were documented in Cores 341-U1420A-92R and 93R (Fig. F7A).

Facies F5b consists of intervals 42 to $140 \mathrm{~cm}$ thick of dark greenish gray (10Y 4/1) mud with dispersed clasts containing small amounts of diatoms and sponge spicules (Table T2; Fig. F6F). Shell fragments were found occasionally, and traces of volcanic ash occur very rarely. Bioturbation is either absent or heavy. Facies F5c contains very dark gray (N 3) to dark greenish gray (5GY 4/1) mud and diamict with foraminifers and rare gastropods (Table T2; Fig. F6G). This facies is 42 to $281 \mathrm{~cm}$ thick. Bioturbation varies from absent to heavy. Very dark gray (N 3) to dark greenish gray (10Y 4/1) diamict and mud with traces of volcanic ash define Facies F7 (Table T2), and intervals commonly range in thickness from 18 to 140 $\mathrm{cm}$.

\section{Lithostratigraphic units}

Based on facies associations, three lithostratigraphic units were defined (Table T3) for Site U1420. The contacts between lithostratigraphic units at Site U1420 are usually not observed because of the poor core recovery. The criteria used to define units are discussed below.

\section{Unit I}

Interval: 341-U1420A-1R-1, $0 \mathrm{~cm}$, to $7 \mathrm{R}-\mathrm{CC}, 0 \mathrm{~cm}$ Depth: Hole U1429A = 0-58.2 m CSF-A

Age: Middle Pleistocene to Holocene

Lithostratigraphic Unit I consists of very dark gray (N 3) muddy clast-rich diamict interbedded with clast-poor diamict with angular to rounded clasts. Clast size ranges from granule to pebble. The diamict beds are massive and have mainly a mud matrix with 
some outsized sand grains, based on smear slide observations. A few beds have a sandy matrix.

\section{Unit II}

Interval: $341-\mathrm{U} 1420 \mathrm{~A}-7 \mathrm{R}-\mathrm{CC}, 0 \mathrm{~cm}$, to $48 \mathrm{R}-1,0 \mathrm{~cm}$ Depth: Hole U1420A $=58.2-448.5 \mathrm{~m}$ CSF-A

Age: Middle Pleistocene to Holocene

Recovery within Unit II ranged from $0 \%$ to $8 \%$. The major lithology was not recovered, and cores mostly contain washed pebbles and cylindrical shaped drilled rocks with abraded surfaces (Fig. F7C-F7G). The cylindrical shape suggests that the minimum diameter of drilled cobbles or boulders exceeded the inner diameter of the drill bit $(6.20 \mathrm{~cm})$. Small amounts of sediment were occasionally recovered (rarely exceeding $10 \mathrm{~cm}$ and usually heavily disturbed).

\section{Unit III}

Interval: 341-U1420A-48R-1, $0 \mathrm{~cm}$, to 106R-CC, 20 $\mathrm{cm}$

Depth: Hole U1420A = 448.5-1014.5 m CSF-A

Age: Middle Pleistocene to Holocene

Lithostratigraphic Unit III consists of very dark gray $(\mathrm{N} 3)$ clast-rich diamict and very dark gray (N 3) to dark gray ( $\mathrm{N} 4$ ) clast-poor diamict interbedded with very dark gray (N 3) to dark greenish gray (10Y 4/1) mud with or without lonestones. Some diamict intervals contain shell fragments. Diamict intervals dominate the unit, but intervals of mud occur in Cores 341-U1420A-51R through 52R, 59R, 60R, 63R, $68 \mathrm{R}, 80 \mathrm{R}, 83 \mathrm{R}, 88 \mathrm{R}, 90 \mathrm{R}$ through 93R, and 99R. The amount of lonestones in massive mud intervals ranges from dispersed to abundant. However, mud without clasts occurs in Cores 80R and 83R. Bioturbation is mostly absent but is moderate to heavy in mud without lonestones. Drilled rocks occur in Cores $75 \mathrm{R}$ through $79 \mathrm{R}$ and $85 \mathrm{R}$, coincident with low core recovery. Two subtle erosional surfaces are observed in Cores 92R and 93R in proximity to clasts that are oriented parallel to the bedding plane (Fig. F7A). Additional intercalated very dark gray (N 3) and dark gray ( $\mathrm{N} \mathrm{4)}$ clast-rich diamict is found in Core 98R (Fig. F6H).

\section{Petrography}

\section{Clast lithologies}

The main lithologies of the drilled rocks, washed pebbles, clasts within the diamict, and lonestones contained in the sediment (Fig. F7A-F7G) are, in order of decreasing abundance: sandstone, siltstone, basalt, and granitoids. The granitoid group includes intermediate and felsic intrusive rocks. Argillite, rhy- olite, and metasandstone represent minor lithologies. The average clast abundance for Site U1420, according to the main lithology types, metamorphic (M), igneous (I), and sedimentary (S), is $\mathrm{M}_{8} \mathrm{I}_{35} \mathrm{~S}_{57}$ (Fig. F8). One clast contained thin veins of copper.

\section{Bulk mineralogy}

$\mathrm{X}$-ray diffraction (XRD) analyses were performed on 39 powdered bulk samples from Hole U1420A to delineate the bulk mineralogy and identify compositional trends with age or depth in the cores. The resulting diffraction patterns are shown in Figure F9, and the relative mineral diffraction peak intensities, as defined in "Lithostratigraphy" in the "Methods" chapter (Jaeger et al., 2014), are listed in Table T4. In general, the mineralogy was uniform downhole, although there are some variations in relative peak intensities. The primary minerals identified include quartz, plagioclase (feldspar), mica (muscovite/illite and biotite), and chlorite and/or kaolinite. Quartz and plagioclase are the dominant peaks, with quartz generally the larger, and chlorite and/or kaolinite are present in all samples. Figure F9B shows the comparative XRD patterns from $4^{\circ}$ to $24^{\circ} 2 \theta$, where the scans were run before and after the samples had undergone a glycolization treatment (see "Lithostratigraphy" in the "Methods" chapter [Jaeger et al., 2014]). This treatment was used to determine the presence of expandable clay minerals (e.g., smectite). The scans generally suggest the presence of expandable clay minerals from $\sim 468 \mathrm{~m}$ CSF-A downhole. Our preliminary findings are similar to the results of Molnia and Hein (1982) from samples collected on the continental shelf of the Gulf of Alaska.

\section{Lithostratigraphy and depositional interpretations}

The distribution of primary sedimentary lithologies and core recovery at Site U1420 is summarized in Fig. F10. With the exception of three intervals of clast-rich and clast-poor diamict between 10 and 50 m CSF-A, core recovery was $<10 \%$ in Units I and II (uppermost $450 \mathrm{~m}$ CSF-A) and largely consisted of drilled rocks and washed pebbles. Core recovery in Unit III increased above $10 \%$ between 450 and 500, 540 and 670, and 750 and 980 m CSF-A. Recovered sediment from these intervals consists of clast-rich and clast-poor diamict, and extensively bioturbated (bioturbation intensity index $=3$ ) dark greenish gray (10Y 4/1) mud with or without clasts is found between 595 and $597 \mathrm{~m}$ CSF-A and between 760 and $780 \mathrm{~m}$ CSF-A. Mud with abundant and common clasts is observed between 860 and $880 \mathrm{~m}$ CSF-A. Two $\sim 50 \mathrm{~m}$ thick intervals with low core recovery 
$(<10 \%)$ are found centered at 525 and $725 \mathrm{~m}$ CSF-A and largely consist of drilled rocks and washed pebbles.

\section{Unit I}

A survey by drill string-mounted camera prior to drilling at Site U1420 revealed smooth seafloor covered by fine-grained sediment with a lone boulder. This part of the depositional sequence was not recovered by drilling (Fig. F10). The top of the recovered record (beginning in Section 341-U1420A-2R-1) contains a massive clast-rich diamict, which is delineated as lithostratigraphic Unit I. We suggest that this diamict was deposited from intense iceberg rafting during glacial times, when icebergs transported and deposited large quantities of debris, along with mud from meltwater plumes. Our suggestion is based primarily on the absence of oriented clasts that frequently occur in subglacial deposits (Benn and Evans, 2010).

An alternative interpretation is that the diamict in Unit I could have been deposited subglacially. This interpretation is based on the stratigraphic position of the upper part of Unit I, located shallower than the regional unconformity shown on the geophysical lines through Site U1420 (Figs. F11). This relationship implies that grounded ice may have overridden Site U1420 during advance(s) across the shelf. Both tentative interpretations for Unit I require additional sediment fabric analyses for verification.

\section{Unit II}

Mainly washed pebbles and drilled rocks (Fig. F7CF7G) with limited fine-grained lithologies were recovered in lithostratigraphic Unit II. It is impossible to interpret the depositional environment of these isolated clasts without the context provided by the matrix and other "missing" fine-grained lithologies. Owing to this limitation, lithofacies from this unit were not included in the lithofacies table (Table T2). Assuming that the diameter of the drilled rock pieces is proportional to the drilled length (up to $30 \mathrm{~cm}$ ) (Fig. F7G), some of the clasts in Unit II are boulder size. This indicates that a significant number of subsurface boulders likely influence drilling and the success of recovery in some intervals (Fig. F10).

Concentrations of boulders in the upper portion of Unit II (located shallower than the regional unconformity) (Fig. F6) may be boulder pavements, potentially formed by lodgment processes beneath grounded glaciers (Powell and Cooper, 2002). Alternatively, they may be similar to the boulder pavements described in the glacimarine Yakataga Formation from Middleton Island, Gulf of Alaska, where they form planar surfaces that can be traced several kilometers along strike (Eyles and Lagoe, 1990; Eyles, 1987).

The sources for clasts documented in Unit II are interpreted to be the onshore St. Elias and Chugach Mountains located along the southern coast of Alaska. Unmetamorphosed siltstone and sandstone clasts, the most common clast types (Fig. F8), may have been derived from the Kulthieth, Poul Creek, and Yakataga Formations. These Cenozoic strata are exposed in the active onshore thrust belt (Plafker, 1987; Pavlis et al., 2012) and are currently being deeply eroded by glaciers. The less common metasedimentary clast lithologies were probably derived from the Mesozoic accretionary prism strata and metamorphic core complex exposed in the Chugach and St. Elias Mountains (Plafker et al., 1994; Gasser et al., 2011). Felsic igneous clasts may have derived from the Sanak-Baranoff plutons found dispersed along the southern Alaska margin (Sisson et al., 2003).

\section{Unit III}

The interbedded diamict and mud in Unit III is interpreted to represent fluctuations in the groundingline position and variations in the supply of icerafted debris and meltwater in a proglacial setting. The dominance of diamict and mud with lonestones suggests the continuous presence of tidewater glaciers on the continental shelf during the deposition of Unit III. The two intervals with poor recovery $(<10 \%)$ and abundant drilled rock in Unit III are suggested to represent periods of enhanced ice rafting. Intervals of massive mud without lonestones and moderate to heavy bioturbation (Facies F1b) were possibly deposited during periods of reduced glacial influence. Diamict intervals with intercalated structures, crude horizontal fabric, and beds that grade upward into mud in the lower parts of Unit III are interpreted to be sediment gravity flow deposits. This interpretation is supported by biological evidence, including shell fragments and the occurrence of shallow-water foraminifers (see "Paleontology and biostratigraphy").

The facies associations described above are similar in many respects to a stratigraphic model for glacial cycling on the Alaskan shelf proposed by Powell and Cooper (2002). Mud without lonestones facies correlate with their "Glacial Minimum Systems Tract," which represents minimum glacial influence. Mud containing lonestones (ranging in abundance) and diamict would have been deposited in distal to proximal glacimarine environments that correlate to the "Glacial Advance Systems Tract" in this model. The 
boulder accumulations in the poor-recovery intervals are suggestive of the most glacier-proximal conditions within the sequence (Fig. F7).

In general, some of the recovered sediment at Site U1420 may include representative sections of glacial sequences as described in the model by Powell and Cooper (2002). We suggest that differences between our observations and the model can be explained by the limited core recovery or local differences in sediment supply and glacial conditions.

\section{Paleontology and biostratigraphy}

Microfossil abundances are generally low in Hole U1420A (Fig. F12). Diatoms and radiolarians are only observed in three intervals. Thus, age constraints are few but collectively suggest that all recovered sediments are younger than 0.7 Ma. Benthic and planktonic foraminifers are better preserved and occur throughout the record. Changes in the composition of the benthic foraminiferal fauna suggest changes in water depth ranging from inner neritic to upper bathyal.

\section{Diatoms}

In order to define the sediment depositional age and paleoenvironmental conditions, core catcher samples and samples from selected split core sections from Hole U1420A were investigated (Table T5). Of the 119 samples analyzed in Hole U1420A, 66 are barren of diatoms.

The only biozone recognized in Hole U1420A is Zone NPD 12 (present-[0.3 \pm 0.1$] \mathrm{Ma}$ ). The base of this zone is defined by the last occurrence (LO) of Proboscia curvirostris (Jousé) Jordan et Priddle (D120; $0.3 \pm 0.1 \mathrm{Ma})$, which was not observed. Thus, we consider all of the retrieved sediment to be within Zone NPD 12. For a detailed description of diatom zonal scheme and taxonomy, see the "Methods" chapter (Jaeger et al., 2014).

Diatoms are generally absent to rare, and when present, valve preservation is poor to moderate (Table T5; Fig. F12). The diversity of the diatom community at Site U1420 is low and mainly consists of Pleistocene to Holocene species. Cold-water species, including N. seminae (Simonsen et Kanaya) Akiba et Yanagisawa, Actinocyclus curvatulus Janisch in Schmidt, and Rhizosolenia hebetata f. hiemalis Gran (Sancetta, 1982; Medlin and Priddle, 1990), are the most abundant (Table T5; Fig. F12). The influence of coastal waters at Site U1420 is suggested by the presence of coastal and benthic diatoms, including resting spores of Chaetoceros, Thalassionema nitzschioides var. nitzschioides (Grunow) Mereschkowsky, and the tycoplanktonic diatom Paralia spp. (Hasle and Syvertsen, 1996).

\section{Radiolarians}

All but three samples are barren of radiolarians (Table T6). In Sample 341-U1420A-16R-1W, 0-5 cm (138.13 m CSF-A), radiolarians are common but poorly preserved. The fauna is characterized by the presence of cold- and shallow-water radiolarians such as Stylochlamydium venustum Bailey and Stylodictya validispina Jørgensen (Kamikuri et al., 2008; Boltovskoy et al., 2010) (Table T6). In Sample 341U1420A-80R-2W, 100-101 cm (761.41 m CSF-A), we observe the datum species Lychnocanoma sakaii Morley and Nigrini, suggesting an age older than 0.03 Ma. The datum species Stylacontharium acquilonium Hays is not encountered, suggesting that the sediment of this interval is younger than $0.4 \mathrm{Ma}$, thereby bracketing the age to between 0.03 and $0.4 \mathrm{Ma}$. A faunal change marked by relatively high abundances of the deepwater species Cycladophora davisiana (>500 m CSF-A; Matul et al., 2011) and Spongopyle osculosa (>500 m CSF-A; Boltovskoy et al., 2010) also occurs in this interval (Table T6), suggesting middle to bathyal water depths (500-1000 m). The time represented by sediments shallower than $100 \mathrm{~m}$ CSF-A is interpreted as a neritic environment $(<200 \mathrm{~m})$ based on the radiolarian faunas.

\section{Foraminifers}

Core catcher and section samples from Hole U1420A were examined for planktonic foraminifers from the $>125 \mu \mathrm{m}$ size fraction in 42 samples (Table T7) and for benthic foraminifers from the $>63 \mu \mathrm{m}$ size fraction in 43 samples (Table T8). Nearly all samples contain grains $>700 \mu \mathrm{m}$; sediment in the sand and silt fractions is also abundant in all samples.

\section{Planktonic foraminifers}

Planktonic foraminifers are present in 26 of the 42 samples examined, with 10 taxonomic groups represented (Table T7). Total abundances of planktonic foraminifers are generally ranked as present, with an exceptionally high abundance (ranked as abundant) in Sample 341-U1420A-16R-1W, 0-5 cm (Fig. F12). Preservation is good except for two samples, which are ranked as moderate (Table $\mathrm{T7}$ ). The occasional presence of orange or brown foraminifers (comments on Table T7) suggests possible diagenetic processes.

Only one specimen of Neogloboquadrina inglei (LO $0.70 \pm 0.1 \mathrm{Ma}$ ) is present in Sample 341-U1420A96R-CC. Judging from the shell texture of that speci- 
men, which lacks the prominent structures found in other neogloboquadrinids in the same sample, it was most likely transported through reworking processes. Planktonic foraminifers at Site U1420 are dominated by Neogloboquadrina pachyderma (sinistral), Globigerina umbilicata, and Globigerina bulloides, suggesting cold-water conditions (Fig. F13). The dextral form of $N$. pachyderma is also present at this site, but its abundance is generally rare to abundant (Table T7), also suggesting a cold-water environment.

\section{Benthic foraminifers}

Benthic foraminifers are present to abundant in 42 of the 43 samples examined, and 38 species or species groups are identified (Table T8). Abundances are generally very low, likely due to the dominance of siliciclastic material in the $63-250 \mu \mathrm{m}$ size fraction, and abundances are greater than present in only six samples. Benthic foraminiferal preservation varies between good and poor, with poor preservation recorded for only $\sim 33 \%$ of the samples (Fig. F12; Table T8).

Elphidium spp. dominates $71 \%$ of the samples (Fig. F14), suggesting that a majority of the record was deposited in inner neritic ( 0-100 $\mathrm{m}$ water depth) environments (Bergen and $\mathrm{O}^{\prime} \mathrm{Neil}, 1979$ ). Middle neritic to upper bathyal ( 100-500 m water depth) sedimentation is suggested between 138.13 and 177.16 $\mathrm{m}$ CSF-A and between 487.54 and $867.04 \mathrm{~m}$ CSF-A by increased relative abundances of taxa found at those depths in the modern Gulf of Alaska, such as Islandiella norcrossi, Uvigerina spp., and Epistominella pacifica (Fig. F14). Variation in the relative abundance of Elphidium spp. versus deeper water taxa could also be controlled by sediment transport from shallower water environments without a change in water depth.

\section{Stratigraphic correlation}

Because only a single hole was drilled/cored at Site U1420, no stratigraphic correlation was performed at this site.

\section{Initial age model}

The shipboard paleomagnetic and biostratigraphic age datums are insufficient for the construction of a detailed initial shipboard age model (see "Paleomagnetism" and "Paleontology and biostratigraphy"). The biostratigraphy indicates that the cored sediments are in modern biozones and the recovered cores are all normal magnetic polarity. Because the Matuyama/Brunhes geomagnetic polarity boundary was not observed, we can conclude that the entire sedimentary sequence recovered at Site U1420 is younger than $0.781 \mathrm{Ma}$.

\section{Geochemistry}

\section{Interstitial water chemistry}

A total of 20 interstitial water (IW) samples were taken from Hole U1420A. Because of variable core recovery in the sandy to gravelly lithologies, the IW sample spacing was irregular. For example, just two samples were taken in the upper part of the hole (Cores 341-U1420A-2R and 5R), followed by a $\sim 430$ $\mathrm{m}$ CSF-A sampling gap. Deeper in the hole (Cores 341-U1420A-51R through 106R), sampling resolution continued to be irregular. Because of these unavoidable sampling gaps, the resulting downhole profiles of chemical parameters may be biased.

Whole rounds for IW analysis in Hole U1420A were 5 to $15 \mathrm{~cm}$ long. The applied squeezing pressures ranged from 8,000 to $32,000 \mathrm{psi}$, and the volumes of IW collected ranged from $8 \mathrm{~mL}$ (in sandy/gravelly material) to $30 \mathrm{~mL}$ (in muddy material). Splits of the IW samples were processed following methods outlined in "Geochemistry" in the "Methods" chapter (Jaeger et al., 2014). Some splits were analyzed at sea, and others were preserved for shore-based analysis of dissolved trace metals, oxygen/sulfur/calcium/strontium isotopes, dissolved inorganic carbon, and silica.

\section{Alkalinity, pH, chloride, and salinity}

The alkalinity and $\mathrm{pH}$ of the sea-surface water (sampled by pumping) at Site U1420 are $2.2 \mathrm{mM}$ and 8.17, respectively. Alkalinity values in IW samples are consistently $<12 \mathrm{mM}$ (Fig. F15A). The highest alkalinity (11.6 mM) was observed at $478.0 \mathrm{~m}$ CSF-A. From this peak, concentrations gradually decrease downhole to a local minimum of $1.6 \mathrm{mM}$ at $653.6 \mathrm{~m}$ CSF-A. A secondary maximum alkalinity of $5.5 \mathrm{mM}$ occurs at $763.3 \mathrm{~m}$ CSF-A, followed by a gradual decrease to $1.2 \mathrm{mM}$ at $1012.5 \mathrm{~m}$ CSF-A. The $\mathrm{pH}$ values range between 7.73 and 8.66 ; the upper range of these values (Fig. F15B) occurs deeper than $800 \mathrm{~m}$ CSF-A.

The sea-surface chloride concentration at Site U1420 is $509 \mathrm{mM}$. In IW samples, a chloride concentration of $>365 \mathrm{mM}$ was recorded in the shallowest sample (10.7 m CSF-A; Core 341-U1420A-2R), as well as between 478.0 and $653.7 \mathrm{~m}$ CSF-A (Cores 341-U1420A51R through 69R) and deeper than $924.8 \mathrm{~m}$ CSF-A (Core 94R) (Fig. F15J). Chloride concentrations were 294-340 mM in Core 341-U1420A-5R (39.4 m CSFA) and Cores 341-U1420A-80R through 94R (763.4878.0 m CSF-A). 
The low concentrations of chloride relative to surface seawater at Site U1420 were also reflected in salinity. The salinity of sea-surface water at Site U1420 is 31 . In pore waters, salinity values $\geq 19$ were recorded in the uppermost sample (10.7 m CSF-A; Core 341-U1420A-2R), between 478.0 and $653.7 \mathrm{~m}$ CSF-A (Cores 341-U1420A-51R through 69R), and deeper than $924.8 \mathrm{~m}$ CSF-A (Core 341-U1420A-94R) (Fig. F15I). The salinity is 16-18 in Core 341-U1420A-5R (39.4 m CSF-A) and Cores 80R through 94R (763.4878.0 m CSF-A).

\section{Dissolved ammonium, silica, and phosphate}

Downcore variations in ammonium concentration often parallel those of alkalinity (Fig. F15D). The highest ammonium concentrations $(2.5 \mathrm{mM})$ were recorded between 478.0 and $596.8 \mathrm{~m}$ CSF-A. At greater depths, ammonium decreased to a local minimum concentration of $1.4 \mathrm{mM}$ at $653.6 \mathrm{~m}$ CSF-A. Another local maximum of $2.1 \mathrm{mM}$ is at $763.3 \mathrm{~m}$ CSF-A, followed by a steep decrease to values near $1.2 \mathrm{mM}$ deeper than $820.1 \mathrm{~m}$ CSF-A.

Silica trends are broadly similar to ammonium and alkalinity over most of the record. In the two uppermost samples (10.7 and $39.4 \mathrm{~m}$ CSF-A), silica decreases from 650 to $424 \mu \mathrm{M}$ (Fig. F15H). A value of $650 \mu \mathrm{M}$ was measured at $478.0 \mathrm{~m}$ CSF-A; concentrations decrease downcore to a local minimum of 206 $\mu \mathrm{M}$ (653.6 m CSF-A). Another local maximum of 782 $\mu \mathrm{M}$ is at $763.3 \mathrm{~m}$ CSF-A, followed by a downcore decrease to $146 \mu \mathrm{M}$ at $1012.5 \mathrm{~m}$ CSF-A. Phosphate concentrations are variable but consistently $<4 \mu \mathrm{M}$; lowest values are at depths deeper than $800 \mathrm{~m}$ CSF-A (Fig. F16J).

\section{Dissolved sulfate, calcium, magnesium, potassium, sodium, and bromide}

Sulfate concentrations at Site U1420 range from 7.6 to $2.2 \mathrm{mM}$ (Fig. F15C). The maximum concentration was recorded in the shallowest sample measured, at $10.7 \mathrm{~m}$ CSF-A. Sulfate concentrations increase slightly from $477.9 \mathrm{~m} \mathrm{CSF-A} \mathrm{to} \mathrm{the} \mathrm{bottom} \mathrm{of} \mathrm{the}$ hole.

Calcium concentrations at Site U1420 are consistently $<20 \mathrm{mM}$ (Fig. F16A). Between 548.0 and 653.6 $\mathrm{m}$ CSF-A, calcium concentrations increase sharply from 5 to $12 \mathrm{mM}$. From 763.3 to $965.1 \mathrm{~m}$ CSF-A, a second downcore increase occurs from 5 to $16 \mathrm{mM}$.

Magnesium concentrations vary between 14.9 and $28.1 \mathrm{mM}$ at Site U1420 (Fig. F16C). Concentrations $>25 \mathrm{mM}$ were found at $10.7 \mathrm{~m} \mathrm{CSF}-\mathrm{A}$ and near $600 \mathrm{~m}$ CSF-A. Deeper than 600 m CSF-A, magnesium concentrations decrease until reaching the minimum value $(14.9 \mathrm{mM})$ at $788.0 \mathrm{~m}$ CSF-A. At greater depths, magnesium increases to $\sim 20 \mathrm{mM}$ by the bottom of the hole.

Potassium concentrations at Site U1420 vary between 5.4 and $2.1 \mathrm{mM}$; the highest measured value is at $10.7 \mathrm{~m}$ CSF-A (Fig. F16B). Values decrease from 3.9 $\mathrm{mM}$ (548.0 CSF-A) to $2.2 \mathrm{mM}$ (788.0 m CSF-A). At greater depths, values remained $<2.5 \mathrm{mM}$.

Sodium concentrations at Site U1420 are highest $(\sim 300 \mathrm{mM})$ at $10.7 \mathrm{~m} \mathrm{CSF}-\mathrm{A}$ (Fig. F15K), between 478.0 and $653.7 \mathrm{~m}$ CSF-A (Cores 341-U1420A-51R through 69R), and deeper than $924.8 \mathrm{~m} \mathrm{CSF-A} \mathrm{(Core}$ 94R). Minima (as low as $\sim 245 \mathrm{mM}$ ) were recorded at $39.35 \mathrm{~m}$ CSF-A and between 788.0 and $829.7 \mathrm{~m}$ CSF-A.

Bromide concentrations at Site U1420 are $<0.6 \mathrm{mM}$ in the two uppermost samples (10.7 and $39.4 \mathrm{~m}$ CSFA) and between 788.0 and $877.9 \mathrm{~m}$ CSF-A. The highest concentrations were recorded between 478 and $653.7 \mathrm{~m}$ CSF-A (0.71 and $0.66 \mathrm{mM}$, respectively) and deeper than $924.8 \mathrm{~m}$ CSF-A (Fig. F15E).

\section{Dissolved manganese, iron, barium, strontium, boron, and lithium}

Dissolved manganese at Site U1420 is $7.3 \mu \mathrm{M}$ in the uppermost sample (10.7 m CSF-A). Values decrease to $3.2 \mu \mathrm{M}$ by $39.4 \mathrm{~m}$ CSF-A (Fig. F16I). In the deepest part of the hole (763.3-1012.5 m CSF-A), manganese increases slightly with depth from 3.0 to $6.0 \mu \mathrm{M}$.

Dissolved iron at Site U1420 ranges between 0 and $0.5 \mu \mathrm{M}$ without any discernible depth trend (Fig. F16H).

Dissolved barium is below detection limit in the uppermost sample at Site U1420 (10.7 m CSF-A) (Fig. F16F). At greater depth, barium concentrations are variable but increase with sediment depth overall, from $6.3 \mu \mathrm{M}$ at $39.4 \mathrm{~m}$ CSF-A to $38.7 \mu \mathrm{M}$ at $938.0 \mathrm{~m}$ CSF-A.

Strontium concentrations increase sharply from 96.6 to $150.5 \mu \mathrm{M}$ between 548.0 and $653.6 \mathrm{~m}$ CSF-A (Fig. F16G). From 763.3 to $965.1 \mathrm{~m}$ CSF-A, there is a second sharp downcore increase in concentrations from 100.4 to $212.1 \mu \mathrm{M}$.

Boron concentrations are 160 and $176 \mu \mathrm{M}$ in the two uppermost samples (Fig. F16E). A maximum concentration of $288 \mu \mathrm{M}$ was measured at $478.0 \mathrm{~m}$ CSF-A. At greater depths, boron concentrations decrease to a local minimum of $101 \mu \mathrm{M}$ (653.6 m CSF-A). Another local maximum of $191 \mu \mathrm{M}$ is at $763.3 \mathrm{~m}$ CSF-A, followed by a gradual concentration decrease to $83 \mu \mathrm{M}$ at 1012.5 m CSF-A.

Lithium concentrations at Site U1420 are highest $(18.0 \mu \mathrm{M})$ in the uppermost sample (10.7 m CSF-A) (Fig. F16D). At greater depths, lithium varies be- 
tween 15.5 and $5.7 \mu \mathrm{M}$ without any clear depth trend.

\section{Volatile hydrocarbons}

Headspace gas samples in Hole U1420A were collected as warranted by sediment recovery; the sampling resolution is relatively low and irregular. Methane was the dominant hydrocarbon gas present, but at very low concentrations $(<11$ ppmv) in Cores 341 U1420A-2R, 4R, and 5R (Fig. F15F). Deeper than 410 $\mathrm{m}$ CSF-A, methane concentrations range between 1,700 and 33,000 ppmv throughout Hole U1420A. Ethane was detected in headspace gas samples deeper than $244.9 \mathrm{~m}$ CSF-A, but concentrations are consistently low ( $<5$ ppmv) (Fig. F15G). The $\mathrm{C}_{1} / \mathrm{C}_{2}$ ratio is correspondingly high $(1,200-35,000)$, indicating no threat to drilling operations.

\section{Bulk sediment geochemistry}

Discrete core samples were analyzed from Site U1420 for total carbon, total nitrogen (TN), and total inorganic carbon. From these analyses, total organic carbon (TOC) and calcium carbonate $\left(\mathrm{CaCO}_{3}\right)$ were calculated as described in "Geochemistry" in the "Methods" chapter (Jaeger et al., 2014) In total, 41 samples were analyzed from Hole U1420A (Cores 341-U1420A-2R through 106R). Discrete samples were selected in collaboration with the Lithostratigraphy group to ensure that the common lithologies were analyzed.

The TOC content at Site U1420 is usually between 0.4 and 0.9 wt $\%$ with no apparent downhole trend (Fig. F17A). The maximum TOC content was found at $866.1 \mathrm{~m}$ CSF-A (1.21 wt\%; Section 341-U1420A91R-1) but was not associated with any obviously biogenic rich lithology (see "Lithostratigraphy").

The TN content at Site U1420 generally is $<0.1 \mathrm{wt} \%$ (Fig. F17B). Elevated TN contents were observed in Cores 341-U1420A-83R and 84R at 788.3, 789.1, and $798.1 \mathrm{~m}$ CSF-A $(0.06,0.07$, and $0.10 \mathrm{wt} \%$, respectively).

Organic carbon to $\mathrm{TN}(\mathrm{C} / \mathrm{N})$ ratios range between 11 and 77 (Fig. F17C). Relatively high values of this ratio occur near $700 \mathrm{~m}$ CSF-A, but otherwise there is no consistent trend with depth.

Measured $\mathrm{CaCO}_{3}$ contents range between 1.4 and 4.2 $\mathrm{wt} \%$ at Site U1420 (Fig. F17D). Relatively high concentrations at the site $(4.2$ and $3.8 \mathrm{wt} \%)$ were associated with mud-rich samples at 558.8 and $788.0 \mathrm{~m}$ CSF-A (Cores 341-U1420A-59R and 83R; see "Lithostratigraphy"). Between 600 and $690 \mathrm{~m}$ CSF-A, $\mathrm{CaCO}_{3}$ contents decrease downcore and then increase around $800 \mathrm{~m} \mathrm{CSF-A.} \mathrm{At} \mathrm{greater} \mathrm{depths,} \mathrm{there}$ is considerable scatter in the data.

\section{Interpretation}

The IW and sediment composition at Site U1420 are consistent with moderate rates of organic matter remineralization. The TOC contents at Site U1420 are low, but respective accumulation rates are substantially higher because of high sedimentation rates (see "Stratigraphic correlation"). Relatively high organic carbon to $\mathrm{TN}(\mathrm{C} / \mathrm{N})$ ratios reflect the dominance of terrigenous organic matter (Walinsky et al., 2009). Determination of inorganic $N$ is required to fully assess marine and terrigenous inputs to the organic matter record at Site U1420.

Higher $\mathrm{C} / \mathrm{N}$ ratios (600-800 m CSF-A) are associated with low $\mathrm{CaCO}_{3}$ and higher TOC contents and lower porosity (see "Physical properties"), consistent with variations in terrigenous input as a source of variability. Deeper than $875 \mathrm{~m}$ CSF-A, scatter in $\mathrm{CaCO}_{3}$ contents and a decrease in TOC are associated with the presence of shallow-water benthic foraminiferal taxa and overall reduced foraminifer abundances (see "Paleontology and biostratigraphy"). Despite the low abundance of biosiliceous microfossils and paucity of volcanic ash (see "Lithostratigraphy"), dissolved silica concentrations are substantially higher than seawater, implying that opal dissolution is occurring within these sediments. The broad similarities between the silica and ammonium profiles suggest coupled dissolution of biosilica and the degradation of biosilica-associated organic matter. This hypothesis is supported by overall lower $\mathrm{C} / \mathrm{N}$ ratios (Fig. F17C) wherever dissolved ammonium and silica are high, suggesting that a higher proportion of reactive marine organic matter is available within these intervals (Fig. F15).

Tracers associated with the intensity of organic matter degradation are inconsistent. Although alkalinity and phosphate are low throughout the record, ammonium concentrations are relatively high (up to $2.5 \mathrm{mM}$ ). Organic matter degradation within the uppermost $40 \mathrm{~m}$ CSF-A and deeper than $478.0 \mathrm{~m}$ CSF-A is low to moderate, implying the presence of refractory terrigenous material. The discrepancy between phosphate/alkalinity and ammonium concentrations can be explained by the rapid consumption of alkalinity and phosphate by authigenic mineral precipitation, whereas the higher ammonium concentrations overall could indicate that few clay minerals are present to act as sorption sites (see "Lithostratigraphy").

Organic matter degradation pathways at Site U1420 seem to be dominated by sulfate reduction and especially methanogenesis; dissimilatory iron and manganese reduction are negligible (Froelich et al., 1979). Total sulfate depletion is not reached at Site U1420, although sulfate reduction may be occurring 
within the uppermost $\sim 40 \mathrm{~m}$ CSF-A, given the onset of methanogenesis shallower than $244 \mathrm{~m}$ CSF-A. However, IW sulfate concentrations are always significantly lower than respective seawater concentrations (by 60\% at $11 \mathrm{~m}$ CSF-A and even lower downcore). This relationship indicates significant dilution through the entire sediment profile by sulfate-poor freshwater, which hinders the determination of the diagenetic component to the sulfate record. The dissolved barium profile precludes contamination with sea-surface water pumped downhole during drilling. The low sulfate concentrations in all but the uppermost sample may influence the dissolution of barite deeper than 10 m CSF-A. However, barium concentrations are extremely low, perhaps because of the limited formation of biogenic barite in shallow-shelf water (von Breymann et al., 1992). Dissolved strontium covaries with calcium, indicating control by the dissolution and precipitation of carbonate minerals.

The chlorinity, salinity, and sodium profiles document significant IW freshening in all recovered samples with respect to the overlying seawater. The freshening is particularly extreme at $39.4 \mathrm{~m} \mathrm{CSF-A}$ and in the interval between 763.4 and $896.2 \mathrm{~m} \mathrm{CSF-}$ A. Dehydration of clay minerals can be excluded as a source of freshwater at Site U1420 because of the relatively shallow burial depth and corresponding low temperature (Saffer and McKiernan, 2009). Low IW salinities have been associated previously with methane hydrate dissociation (e.g., Hesse, 2003; Torres et al., 2004). However, given the low to moderate methane concentrations analyzed in headspace samples, methane hydrate dissociation is an unlikely explanation for IW freshening at Site U1420. Alternatively, studies on marine IW salinities adjacent to modern ice sheets of Greenland (Ocean Drilling Program Leg 152; Gieskes et al., 1998; DeFoor et al., 2011) and Antarctica (Lu et al., 2010) suggest that substantial IW freshening might be related to glacial meltwater discharge events. Site U1420 is located within a glacial shelf-crossing trough (Carlson and Bruns, 1997; Worthington et al., 2010), and the IW freshening may be related to burial of freshwater associated with glacial meltwater or associated with modern submarine groundwater discharge driven by onshore/nearshore hydrostatic gradients.

To estimate the impact of freshwater dilution on the IW profiles, concentrations of all chemical parameters were normalized to downcore chloride concentrations. Selected normalized profiles are shown in Figure F18. Although bromide and magnesium profiles deeper than $760 \mathrm{~m}$ CSF-A are affected by dilution from less saline waters, all other profiles maintain their original trends after normalization. The upper boundary of the low-salinity layer (600-650 m CSF-A) is also a sink for ammonium, alkalinity, and magnesium and a source of calcium and strontium, which could reflect the dissolution of biogenic calcite and precipitation of authigenic dolomite. In contrast, within the low-salinity layer (deeper than $763 \mathrm{~m}$ CSF-A), sinks in ammonium, alkalinity, calcium, and strontium co-occur. These initial IW composition patterns indicate that at least two distinct fluid bodies must be present at Site U1420, separated at $\sim 650 \mathrm{~m}$ CSF-A. Physical properties data indicate a drop in porosity and an increase in bulk density at the top of the low-salinity layer, which could indicate that the less saline waters deeper than this depth are protected from diffusive equilibration with the overlying, more saline waters (see "Physical properties").

\section{Physical properties}

Physical properties measurements were taken at Site U1420 to provide basic information for characterizing the drilled section using whole-round cores, split cores, and discrete samples. After cores were divided into sections, all whole-round core sections longer than $\sim 30 \mathrm{~cm}$ were measured with the gamma ray attenuation (GRA) bulk densitometer and magnetic susceptibility loop on the Whole-Round Multisensor Logger (WRMSL) at $2.5 \mathrm{~cm}$ intervals with $5 \mathrm{~s}$ measurements. $P$-wave velocity was not measured on the WRMSL for this site, as RCB core diameter is insufficient to fill the liners (see "Physical properties" in the "Methods" chapter [Jaeger et al., 2014]) for a discussion of technical limitations of the $P$-wave logger system on the WRMSL). After WRMSL scanning, the whole-round sections were logged for natural gamma radiation (NGR) at $10 \mathrm{~cm}$ intervals. Color spectrometry, color reflectance, and point magnetic susceptibility were measured on the split cores using the Section Half Multisensor Logger at $2.5 \mathrm{~cm}$ resolution. Discrete measurements of $P$-wave and shear strength were made using the working-half sections of split sediment cores using the Section Half Measurement Gantry. Moisture and density (MAD) were also measured on $10 \mathrm{~cm}^{3}$ plugs collected from the working halves. A summary of all the physical properties measured at this site, except for vane shear strength, is provided in Figure F19.

\section{Gamma ray attenuation bulk density}

Variations in GRA bulk density in the recovered sections of Site U1420 likely reflect changes in mineralogy/lithology, consolidation, and porosity, which are overprinted by variable core recovery. Whole-round GRA bulk density averages $\sim 1.8 \mathrm{~g} / \mathrm{cm}^{3}$ in the RCB 
cores and displays downhole variability on the order of $\sim 0.3 \mathrm{~g} / \mathrm{cm}^{3}$ (Fig. F19). The WRMSL GRA bulk densitometer is calibrated for a core diameter equivalent to $6.6 \mathrm{~cm}$ (see "Physical properties" in the "Methods" chapter (Jaeger et al., 2014), but this diameter of cored sediment was not recovered at Site U1420. Consequently, the densities recovered via the WRMSL measurement system should be regarded as minimum estimates, and the range in observed densities is likely influenced by the highly variable diameter of the recovered cores.

\section{Magnetic susceptibility}

As is the case for the WRMSL GRA, the loop magnetic susceptibility meter is calibrated assuming the diameter of the core equivalent to the interior width of the core liner. Thus, although magnetic susceptibility data were collected in a raw form, the absolute values reflect a minimum estimate of magnetic susceptibility. The relationship between loop magnetic susceptibility and point-source magnetic susceptibility is likely to be driven by the volume of sediment in the WRMSL measurement window and cannot be expected to meaningfully reflect instrument reproducibility.

We normalize loop magnetic susceptibility for changes in sediment recovery and compaction by dividing the volumetric susceptibility by the GRA bulk density after smoothing with a Gaussian filter of 10 $\mathrm{cm}( \pm 3 \sigma)$ to correct for the differing response functions of the instruments. This generates a mass magnetic susceptibility $(\chi)$ with units of cubic centimeters per gram. (Fig. F20). This normalization by GRA bulk density reduces downcore variance in $\chi$ by $\sim 15 \%$, relative to the equivalently smoothed raw WRMSL magnetic susceptibility data normalized by the mean core density. Mass magnetic susceptibility averages $\sim 54.3 \mathrm{~cm}^{3} / \mathrm{g}$ downhole at the site (Fig. F20). Several successions of variability between 25 and 70 $\mathrm{cm}^{3} / \mathrm{g}$ are recovered in the core deeper than $550 \mathrm{~m}$ CSF-A, and susceptibility appears to increase deeper than $940 \mathrm{~m}$ CSF-A, although limited core recovery hinders interpretation.

\section{Compressional wave velocity}

$P$-wave measurements using the $P$-wave caliper (PWC) tool (see "Physical properties" in the "Methods" chapter (Jaeger et al., 2014) were taken at Site U1420 when core recovery allowed. Because of poor core recovery, only one PWC measurement was taken shallower than $449 \mathrm{~m}$ CSF-A. Much of the recovered material deeper than $\sim 449$ m CSF-A consists of clast-rich or clast-poor diamict (see "Lithostratigraphy"). The nature of this material caused uneven contact with the PWC, so velocity measurements could not be obtained with regularity. PWC values were automatically picked where possible and manually picked when the automatic picker encountered errors because the calipers did not have sufficient contact with the sample because of abundant clasts, soft sediment, or bad coupling with the liner. PWC values show no significant overall trend with depth and vary widely, sometimes within the same section, likely because of the varying amounts and lithology of clasts. Though values generally range from $\sim 1500$ to $\sim 2000 \mathrm{~m} / \mathrm{s}$, occasional measurements of velocities $>2200 \mathrm{~m} / \mathrm{s}$ were also observed (Fig. F21). All discrete measurements at this site were taken within the dominant matrix lithology of the recovered interval.

\section{Natural gamma radiation}

NGR was measured at $10 \mathrm{~cm}$ intervals on all wholeround core sections that exceeded $50 \mathrm{~cm}$ in length (Fig. F19). NGR measurements show recurring downcore fluctuations between 13 and 35 counts per second (cps) with a mean and standard deviation of 27 and 3 cps, respectively. Downhole variations in raw NGR values are influenced by changes in core recovery volume and consequently parallel changes in GRA bulk density.

As with WRMSL magnetic susceptibility, we calculate an equivalent activity of the sediment by normalizing to the WRMSL GRA bulk density after smoothing the data sets with a Gaussian filter of 50 $\mathrm{cm}( \pm 3 \sigma)$ to accommodate for the varying response functions of the instruments. This normalization by GRA bulk density reduces downcore variance in NGR by $\sim 45 \%$. Low-frequency variability in equivalent NGR activity is limited in the recovered cores (Fig. F22), although an increase in activity deeper than $940 \mathrm{~m}$ CSF-A parallels changes in normalized magnetic susceptibility $(\chi)$ and may reflect a change in lithology.

\section{Moisture and density}

Bulk density values in Hole U1420A were calculated from mass and volume measurements on discrete samples taken from the working halves of split cores (see "Physical properties" in the "Methods" chapter [Jaeger et al., 2014]). Depending on core recovery, quality, and lithology, one to three samples were taken per core. A total of 93 samples were analyzed for MAD.

Bulk density values range from 2.0 to $2.4 \mathrm{~g} / \mathrm{cm}^{3}$. The intervals between $\sim 40$ and $440 \mathrm{~m}$ CSF-A and between $\sim 490$ and $540 \mathrm{~m}$ CSF-A were not recovered. Deeper than 450 m CSF-A, MAD densities decrease downhole from $\sim 2.2-2.3$ to $\sim 2.1 \mathrm{~g} / \mathrm{cm}^{3}$ by $\sim 570 \mathrm{~m} \mathrm{CSF-A}$ 
(Fig. F23A). At $\sim 580 \mathrm{~m}$ CSF-A, densities rise to $2.3 \mathrm{~g} / \mathrm{cm}^{3}$ and remain relatively steady to $\sim 650 \mathrm{~m}$ CSF-A. From $\sim 650$ to $700 \mathrm{~m}$ CSF-A, densities increase from $\sim 2.2$ to $\sim 2.4 \mathrm{~g} / \mathrm{cm}^{3}$. Deeper than $\sim 750 \mathrm{~m}$ CSF-A, densities increase from $\sim 2.0-2.4$ to $\sim 2.3-2.4 \mathrm{~g} / \mathrm{cm}^{3}$ (Fig. F23B). Bulk grain density values display scatter from $\sim 2.7$ to $3.0 \mathrm{~g} / \mathrm{cm}^{3}$ downcore and do not appear to correspond with lithostratigraphic trends or patterns (Fig. F24).

Porosity measured on discrete samples generally decreases with depth, with deviations toward higher values. These higher values were identified as mud intervals based on lithology (see "Lithostratigraphy"). Porosity decreases from $\sim 30 \%-48 \%$ to $\sim 25 \%-$ $40 \%$ from $\sim 450$ to 1030 m CSF-A. Mud densities are higher than diamict, which may reflect the influence of clasts on the consolidation of the matrix lithology (Fig. F24).

\section{Shear strength}

Shear strength measurements were performed on working section halves from Hole U1420A using the automated vane shear testing system (see "Physical properties" in the "Methods" chapter [Jaeger et al., 2014]). Efforts were taken to avoid the locations of obvious drilling disturbance or cracks in the halfcore sample. Measurements were taken as close as possible to the positions of the MAD samples and PWC measurements. We obtained only four shear strength measurements, all shallower than $40 \mathrm{~m}$ CSF-A, because of poor recovery from 0 to $\sim 449 \mathrm{~m}$ CSF-A. When recovery increased at $\sim 449 \mathrm{~m}$ CSF-A, the recovered material cracked upon penetration of the vane and we halted automated vane shear measurements. Shear strength measurements indicate that sediments within the shallowest $\sim 40 \mathrm{~m}$ CSF-A are soft $(\sim 20 \mathrm{kPa})$. All samples reflect the dominant lithology of the recovered sediment.

\section{Paleomagnetism}

The natural remanent magnetization (NRM) of Site U1420 archive-half cores was measured before and after alternating field (AF) demagnetization. Peak AFs were restricted to a maximum of $20 \mathrm{mT}$ for most sections recovered using the RCB system, although peak AFs of $40 \mathrm{mT}$ were occasionally used (Table T9). Reduced core recovery allowed a five-step demagnetization procedure with peak AFs of $0,5,10,15$, and 20 $\mathrm{mT}$ to be routinely employed. In addition to the typical measurement interval of $2.5 \mathrm{~cm}$, a $1 \mathrm{~cm}$ interval was used on sections with limited recovery of undisturbed sediment. Sections completely disturbed by drilling, as noted by the Lithostratigraphy and/or
Paleomagnetism groups, were not measured. Lonestones were removed prior to measurement when possible to avoid their undue influence on the magnetic signal. Data associated with intervals affected by obvious drilling deformation were culled during data processing.

The NRM intensities in Hole U1420A are relatively strong before $\left(10^{-2} \sim 10^{-1} \mathrm{~A} / \mathrm{m}\right)$ and after AF demagnetization at peak fields of $20 \mathrm{mT}\left(10^{-3}\right.$ to $\left.10^{-2} \mathrm{~A} / \mathrm{m}\right)$. Intensities systematically drop through $\mathrm{AF}$ demagnetization using peak AFs from 5 to $20 \mathrm{mT}$ and are consistent throughout the drilled interval (Fig. F25). Intervals of clast-rich diamict usually have higher intensities than those associated with clast-poor facies (see "Lithostratigraphy").

After AF demagnetization, inclinations average around values expected (approximately $\pm 73.5^{\circ}$ ) for a geocentric axial dipole at the site latitude, but values significantly steeper or shallower than expected are not uncommon. These variations are likely associated with heterolithic facies that are common at this site. The magnetic moment of sand, gravel, and cobbles is likely to be randomly oriented, compared with the finer sediment matrix that appears, when recovered without abundant clasts, to be well aligned with the geomagnetic field.

Because inclinations at Site U1420 are exclusively positive, indicative of normal polarity (Fig. F25), it is thought that the sediment recovered over the 1014 $m$ CSF-A drilled interval is exclusively within the Brunhes Chronozone and younger than $0.781 \mathrm{Ma}$ (Cande and Kent, 1995; Hilgen et al., 2012). The assignment of this normal polarity interval to the Brunhes Chronozone is consistent with the radiolarian biostratigraphy (see "Paleontology and biostratigraphy").

\section{Downhole logging Logging operations}

Logging operations for Site U1420 began after completion of RCB operations in Hole U1420A, which was drilled to a total depth of $1020.8 \mathrm{~m}$ DSF at 1310 h on 20 July 2013. In preparation for logging, $50 \mathrm{bbl}$ of high-viscosity mud was circulated to clean the hole. Because of high torque, further remediation was needed to prepare the hole for logging (see "Operations"). Another $75 \mathrm{bbl}$ sweep was pumped, the pipe was raised to $981.2 \mathrm{~m}$ DSF, and the bit was released at $983.6 \mathrm{~m}$ DSF. The hole was then displaced with $450 \mathrm{bbl}$ of barite-weighted mud (10.5 ppg), and the pipe was raised to $93.3 \mathrm{~m}$ DSF for logging.

Because of concerns regarding borehole stability based on poor core recovery and challenging coring 
conditions, only one logging tool string was deployed in Hole U1420A. This Sonic-induction tool string was designed to provide the highest priority measurements to meet science objectives with the lowest risk to logging tools. The tool string was composed of the Enhanced Digital Telemetry Cartridge, Hostile Environment Litho-Density Sonde (HLDS) without neutron source, Dipole Shear Sonic Imager (DSI), and Phasor Dual Induction-Spherically Focused Resistivity Tool, measuring total gamma ray, borehole diameter, sonic velocity, and resistivity (Fig. F26).

The Sonic-induction tool string was rigged up at $0630 \mathrm{~h}$ on $21 \mathrm{July}$. The tool string was found to be drawing too large a current and, after testing each of the tools, the DSI was determined to be at fault. The DSI was replaced with a back-up tool, and the tool string was lowered into the hole at $1020 \mathrm{~h}$ on 21 July. A downlog was recorded at a speed of $2800 \mathrm{ft} / \mathrm{h}$. At $238 \mathrm{~m}$ WSF ( $150 \mathrm{~m}$ below the pipe), the wireline heave compensator settings were tested in order to minimize downhole tool motion during logging. The downlog continued, reaching $288 \mathrm{~m}$ WSF, where the tool string was blocked and unable to progress deeper into the hole. From this depth, the first upward pass commenced at $2800 \mathrm{ft} / \mathrm{h}$ and ended just below the pipe depth. The tool string was run back into the hole, and a second upward pass began at $1419 \mathrm{~h}$ from $288 \mathrm{~m}$ WSF at $2800 \mathrm{ft} / \mathrm{h}$. All logging tools were rigged down, logging operations were ended, and the rig floor was clear by $2335 \mathrm{~h}$ on 21 July. During logging operations for Hole U1420A, the heave was relatively low ( $0.6 \mathrm{~m}$, peak-to-peak average).

\section{Data processing and quality assessment}

The logging curves were depth-matched using the gamma ray measurement from the second pass of the sonic-induction tool string as a reference log, facilitating the generation of a unified depth scale. Logging data were then depth-shifted to the seafloor reference based on the step increase observed in gamma ray measurement from the downlog of the tool string, the only logging pass to record the seafloor in this hole. The seafloor was measured at 259 $\mathrm{m}$ wireline log depth below rig floor (WRF) and the resulting depth scale is wireline log matched depth below seafloor (WMSF).

Figure F27 shows a summary of the main logging data recorded in Hole U1420A. The caliper measurement shows that the borehole diameter exceeded 18 inches, the limit of the HLDS caliper arm, over several large depth intervals (Fig. F27). Borehole diameter was smaller ( 15 inches) between $\sim 140$ and 200 $\mathrm{m}$ WMSF. Despite the large borehole size, the data seem to be of good quality, as measurements showed relatively consistent variability throughout the logged interval. A comparison of the two passes of the Sonic-induction tool string indicates reproducibility for all measurements (Fig. F28). In an interval where gamma ray drops dramatically $(\sim 130-140 \mathrm{~m}$ WMSF) and borehole diameter is $>18$ inches, there remains a coherent response in the resistivity data. The deep resistivity measurement (shown in red in Fig. F27) has an average radial depth of investigation of $>1.2 \mathrm{~m}$ even at very low resistivity $(0.1 \Omega \mathrm{m})$, and the depth of investigation increases in higher resistivity formations. Thus resistivity is a reliable measurement even in wider boreholes.

The DSI recorded P\&S monopole and lower and upper dipole modes in Hole U1420A, with standard (high) frequency for the monopole and upper dipole and low frequency for the lower dipole. The high coherence in sonic waveforms indicated by orange-red areas in the compressional velocity track (Fig. F27) suggests that the DSI was successful in capturing compressional arrivals through most of the logged interval, whereas there is low or no coherency in the shear wave arrivals. Higher velocities are shown in the intervals of smaller borehole diameter, which may be partially controlled by lithology, but also suggests that $P$-wave velocities recorded through wider borehole intervals may underestimate true formation velocity.

\section{Logging stratigraphy}

\section{Logging Unit I}

The logged interval in Hole U1420A was assigned to a single logging unit based on the minimal measurements recorded and the limited depth interval of the logging data in the context of the entire drilled depth. However, on the basis of distinctive changes in resistivity and velocity measurements, Logging Unit 1 has been divided into five subunits (Fig. F27).

\section{Logging Subunit $1 A$ (base of drill pipe to $129 \mathrm{~m}$ WMSF)}

Logging Subunit $1 \mathrm{~A}$ is characterized by very little net downhole variation in all data types (Fig. F27). Gamma ray data vary around an average of 36 gAPI. Resistivity and $P$-wave velocity are relatively constant with depth. Resistivity values range from 2.4 to $3.8 \Omega \mathrm{m}$, and the mean $P$-wave velocity is $\sim 1930 \mathrm{~m} / \mathrm{s}$. The borehole diameter for this subunit is $\sim 18$ inches.

\section{Logging Subunit 1B (129-140 m WMSF)}

Logging Subunit $1 \mathrm{~B}$ is distinguished by abrupt decreases in gamma ray and resistivity measurements. The mean gamma ray value drops to 23 gAPI. There is a distinct separation between the shallow and me- 
dium resistivity curves and the deep resistivity curve (Fig. F27). The deep curve (mean $=2.1 \Omega \mathrm{m}$ ) likely reflects formation resistivity, whereas the shallow and medium curves are mostly likely dominated by the resistivity of the borehole fluid, given the large borehole diameter. $P$-wave data coherence drops dramatically in this subunit (Fig. F27).

\section{Logging Subunit 1C (140-172 m WMSF)}

The Subunit IB/IC boundary is marked by a change in borehole diameter to values $<18$ inches and abrupt changes in all logging measurements (Fig. F27). Gamma ray values are elevated relative to those shallower in the hole, with a mean of 44 gAPI. Both resistivity and $P$-wave velocity increase with depth in this subunit, from $\sim 3$ to $6 \Omega \mathrm{m}$ and from $\sim 1600$ to $2200 \mathrm{~m} / \mathrm{s}$, respectively.

\section{Logging Subunit 1D (172-190 m WMSF)}

Logging Subunit 1D has a borehole diameter similar to that of Subunit 1C. Gamma ray values are slightly reduced relative to the shallower subunit $($ mean $=40$ gAPI). Resistivity increases at the Subunit 1C/1D boundary (Fig. F27). The highest resistivity values measured in the logged interval occur within this subunit, with a maximum resistivity $>8 \Omega \mathrm{m}$. There is also an abrupt increase in $P$-wave velocity across the subunit boundary, with the highest velocity values recorded in the borehole $($ mean $=2375 \mathrm{~m} / \mathrm{s})$.

\section{Logging Subunit 1E (190-282 m WMSF [base of logged interval])}

Borehole diameter is $<18$ inches at the top of Subunit $1 \mathrm{E}$ but increases to $>18$ inches below $\sim 204 \mathrm{~m}$ WMSF (Fig. F27). Gamma ray values decrease slightly with depth, with a mean value of 37 gAPI. Resistivity decreases from the top of the subunit to $\sim 220 \mathrm{~m} \mathrm{WMSF}$ and is relatively constant at deeper depths, ranging between 3.4 and $6.2 \Omega \mathrm{m}$. $P$-wave velocity data show a similar trend, decreasing with depth to $\sim 220 \mathrm{~m}$ WMSF and then varying locally around $\sim 2050 \mathrm{~m} / \mathrm{s}$. There are correlated changes (peaks/troughs) in deep resistivity and $P$-wave velocity in this subunit. These local variations are most likely true responses to changing formation properties, which could be true increases/decreases in measured values or simply responses to changing borehole size that are also linked to lithology.

\section{Resistivity}

Electrical resistivity measured in Hole U1420A is distinctively different than that measured at Sites U1417 and U1418 (Fig. F29), although measurements at all three sites fall within the typical range of formation resistivity for clay/shale (2-10 $\Omega \mathrm{m}$; from Tittman, 1986). In Holes U1417E and U1418F, resistivity ranged from $\sim 0.6$ to $3.0 \Omega \mathrm{m}$, whereas resistivity values in Hole U1420A are generally $>3.0 \Omega \mathrm{m}$, with the deepest resistivity curve showing values $>8$ $\Omega m$ in logging Subunit 1D (Figs. F27, F29).

Because of limited core recovery in the logged interval in Hole U1420A ( $<4 \%)$, it is difficult to speculate with confidence about the source of high resistivity. Formation resistivity is frequently controlled by the amount and distribution of water in a formation. When a formation is porous and contains saline water (e.g., resistivity of seawater at $24^{\circ} \mathrm{C}$ is $0.19 \Omega \mathrm{m}$ ), its resistivity will be relatively low. High resistivity values may indicate a number of things: low porosity, a porous formation containing freshwater, or some degree of both. However, a formation's resistivity depends on more than simply the amount of water it contains; this measurement is also responsive to lithology, compaction, overpressure, texture, and conductive minerals (e.g., Ellis and Singer, 2007). Rock materials themselves have high resistivity, but when a formation is also porous and all other factors are equal, the fresher the pore fluid, the greater the resistivity. The logged interval in Hole U1420A may contain both high-resistivity formation and relatively fresh pore fluid. The relatively high velocity values ( 1700 to $>2500 \mathrm{~m} / \mathrm{s})$ measured within this shallow logged interval (from $\sim 92$ to $282 \mathrm{~m}$ WMSF) support the idea that high resistivity is not simply due to the presence of freshwater in the formation. Although there is no significant core material to confirm, this interpretation is consistent with the recovery of pebbles and rocks in cores through the same depth interval (see "Lithostratigraphy") and with reduced salinity measured in IW samples through the entire borehole (see "Geochemistry").

\section{Core-log-seismic integration}

Three seismic profiles cross Site U1420: GOA2505 (Fig. F30) and GOA2502 (Fig. F31), acquired in 2004 aboard the R/V Maurice Ewing, and STEEP09 (Fig. F2), acquired in 2008 aboard the R/V Marcus Langseth. In preparation for core-log-seismic integration, we interpreted key seismic horizons that mark a change in acoustic facies or a reflector truncation surface. Horizons $\mathrm{H} 1, \mathrm{H} 2$, and $\mathrm{H} 3$ were previously interpreted by Worthington et al. (2008, 2010). Here, we name subhorizons using the Worthington et al. $(2008,2010)$ naming convention. Additional internal packages are broken out, defined by either a high-amplitude, continuous reflector or a minor change in seismic character.

For preliminary correlation between Site U1420 lithostratigraphic and logging units with features ob- 
served in seismic data, we converted lithostratigraphic and logging unit boundaries from depth in meters CSF-A/WMSF to TWT using the average sonic velocity of each unit. Average $P$-wave velocity was derived from core physical properties measurements using data from the PWC within lithostratigraphic Unit I and the downhole sonic logs at depths between $~ 94$ and $282 \mathrm{~m}$ WMSF (see "Physical properties" and "Downhole logging"). Below $282 \mathrm{~m}$ WMSF, we used values calculated from a linear trendline of the downhole sonic log. We weighted the trendline with the lower velocity PWC-determined values measured deeper in the hole. Based on correlations between the sonic logs and PWC values at previous sites, PWC velocities appear to be reduced within intervals of diamict. Because most of the recovered lithology was diamict, we favor the higher velocity trend recorded in the sonic log data. Detailed correlations in this part of the drilled interval require postcruise core-log-seismic analyses.

Each of the seismic profiles exhibits a distinct change in stratal architecture across the regional unconformity marked by Horizon H1 (Fig. F1). At Site U1420, the seismic packages above Horizon H1 are acoustically semitransparent and semichaotic (Figs. F30, F31). Three subpackages are present, bounded by Subhorizons H1A and H1B. Truncations above and below each of these subhorizons indicate that these are erosional surfaces, likely related to glacial dynamics. According to the TWT-depth conversion using both the PWC and extrapolated sonic log values, Subhorizon H1A likely corresponds to the boundary between lithostratigraphic Units I and II (Fig. F11). Lithologically, Unit I is characterized by muddy clast-rich diamict intervals interbedded with clast-poor diamict.

In lithostratigraphic Unit II, core recovery was $<10 \%$ and the recovered material consisted primarily of washed pebbles and drilled clasts of varying lithologies (see "Lithostratigraphy"). Assuming that the drilled length of the clasts is representative of the average maximum length, some of the clasts in Unit II are boulder grain size. Using the sonic log for TWTdepth conversions, logging data (from $\sim 95$ to $282 \mathrm{~m}$ WMSF) can be used to characterize a portion of lithostratigraphic Unit II that starts between Subhorizons $\mathrm{H} 1 \mathrm{~A}$ and $\mathrm{H} 1 \mathrm{~B}$ and continues across the $\mathrm{H} 1$ unconformity and deeper than Subhorizon H2A (Fig. F11). Logging Subunit 1B, defined by an abrupt decrease in both resistivity and NGR (see "Downhole logging"), may coincide with Subhorizon H1B and a transition from seismic transparent facies to stronger coherent reflectors above Horizon H1 (Fig. F11). Logging Subunit 1D, defined by a section of high velocity (average $=\sim 2300 \mathrm{~m} / \mathrm{s}$ ) and high resistivity (see
"Downhole logging"), appears to tie with Horizon H1. Logging Subunit 1E coincides with the uppermost aggradational packages that are truncated by Horizon H1 and includes Subhorizon H2A.

Deeper than logging Subunit 1E (>282 m CSF-A/ WMSF; Fig. F11), we observe increasing disparity between $P$-wave velocities measured by the PWC and those extrapolated from the downhole sonic log. This velocity discrepancy creates potential errors in TWT calculation that are cumulative with depth in borehole. For example, the possible TWT at the base of the drilled interval has a range of up to $200 \mathrm{~ms}$. Figure F11 includes both sets of correlations, but postcruise analysis will be essential for further interpretations. Shipboard results indicate that the lithostratigraphic Unit II/III boundary lies somewhere within the package of bright, continuous reflectors deeper than Subhorizon H2B. Core recovery increased at the top of lithostratigraphic Unit III, and the sediment within this unit consists primarily of clast-poor and clast-rich muddy diamict with occasional intervals of mud with or without clasts (see "Lithostratigraphy"). Based on the traveltime range estimated from our depth-TWT relationships, two intervals of low core recovery (at $\sim 500-540$ and 705-750 m CSF-A) within lithostratigraphic Unit III may well be associated with distinct seismic features deeper in the section than Subhorizon H2B.

\section{References}

Benn, D.I., and Evans, D.J.A., 2010. Glaciers and Glaciation (2nd ed.): London (Hodder Arnold Publ.).

Bergen, F.W., and O'Neil, P., 1979. Distribution of Holocene foraminifera in the Gulf of Alaska. J. Paleontol., 53(6):1267-1292. http://www.jstor.org/stable/ 1304134

Berger, A.L., Gulick, S.P.S., Spotila, J.A., Upton, P., Jaeger, J.M., Chapman, J.B., Worthington, L.A., Pavlis, T.L., Ridgway, K.D., Willems, B.A., and McAleer, R.J., 2008. Quaternary tectonic response to intensified glacial erosion in an orogenic wedge. Nat. Geosci., 1:793-799. doi:10.1038/ngeo334

Boltovskoy, D., Kling, S.A., Takahashi, K., and Bjørklund, K., 2010. World atlas of distribution of Recent polycystina (Radiolaria). Palaeontol. Electron., 13:1-229. http:// palaeo-electronica.org/2010_3/215/index.html

Cande, S.C., and Kent, D.V., 1995. Revised calibration of the geomagnetic polarity timescale for the Late Cretaceous and Cenozoic. J. Geophys. Res.: Solid Earth, 100(B4):6093-6095. doi:10.1029/94JB03098

Carlson, P.R., and Bruns, T.R., 1997. Bering Trough: a product of the Bering Glacier, Gulf of Alaska. In Davies, T.A., Bell, T., Cooper, A.K., Josenhans, H., Polyak, L., Solheim, A., Stoker, M.S., and Stravers, J.A. (Eds.), Glaciated Continental Margins: An Atlas of Acoustic Images: London 
(Chapman and Hall), 244-247. doi:10.1007/978-94011-5820-6_85

Chapman, J.B., Pavlis, T.L., Gulick, S., Berger, A., Lowe, L., Spotila, J., Bruhn, R., Vorkink, M., Koons, P., Barker, A., Picornell, C., Ridgway, K., Hallet, B., Jaeger, J., and McCalpin, J., 2008. Neotectonics of the Yakutat collision: changes in deformation driven by mass redistribution. In Freymueller, J.T., Haeussler, P.J., Wesson, R.L., and Ekström, G. (Eds.), Active Tectonics and Seismic Potential of Alaska. Geophys. Monogr., 179:65-81. doi:10.1029/179GM04

DeFoor, W., Person, M., Larsen, H.C., Lizarralde, D., Cohen, D. and Dugan, B., 2011. Ice sheet-derived submarine groundwater discharge on Greenland's continental shelf. Water Resour. Res., 47(7):W07549. doi:10.1029/2011WR010536

Ellis, D.V., and Singer, J.M., 2007. Well Logging for Earth Scientists (2nd ed.): New York (Elsevier).

Eyles, C.H., 1987. Glacially influenced submarine-channel sedimentation in the Yakataga Formation, Middleton Island, Alaska. J. Sediment. Petrol., 57(6):1004-1017. doi:10.1306/212F8CCE-2B24-11D78648000102C1865D

Eyles, C.H., and Lagoe, M.B., 1990. Sedimentation patterns and facies geometries on a temperate glacially-influenced continental shelf: the Yakataga Formation, Middleton Island, Alaska. In Dowdeswell, J.A., and Scourse, J.D. (Eds.), Glacimarine Environments: Processes and Sediments. Geol. Soc. Spec. Publ., 53(1):363-386. doi:10.1144/GSL.SP.1990.053.01.21

Froelich, P.N., Klinkhammer, G.P., Bender, M.L., Luedtke, N.A., Heath, G.R., Cullen, D., Dauphin, P., Hammond, D., Hartman, B., and Maynard, V., 1979. Early oxidation of organic matter in pelagic sediments of the eastern equatorial Atlantic: suboxic diagenesis. Geochim. Cosmochim. Acta, 43(7):1075-1090. doi:10.1016/00167037(79)90095-4

Gasser, D., Bruand, E., Stüwe, K., Foster, D.A., Schuster, R., Fügenschuh, B., and Pavlis, T., 2011. Formation of a metamorphic complex along an obliquely convergent margin: structural and thermochronological evolution of the Chugach Metamorphic Complex, southern Alaska. Tectonics, 30(2):TC2012. doi:10.1029/ 2010TC002776

Gieskes, J.M., Schrag, D., Chan, L.-H., Zhang, L., and Murray, R.W., 1998. Geochemistry of interstitial waters. In Saunders, A.D., Larsen, H.C., and Wise, S.W., Jr. (Eds.), Proc. ODP, Sci. Results, 152: College Station, TX (Ocean Drilling Program), 293-305. doi:10.2973/ odp.proc.sr.152.228.1998

Hasle, G.R., and Syvertsen, E.E., 1996. Marine diatoms. In Tomas, C.R. (Ed.), Identifying Marine Diatoms and Dinoflagellates: San Diego (Academic Press), 5-385. doi:10.1016/B978-012693015-3/50005-X

Hesse, R., 2003. Pore water anomalies of submarine gashydrate zones as tool to assess hydrate abundance and distribution in the subsurface-what have we learned in the past decade? Earth-Sci. Rev., 61(1-2):149-179. doi:10.1016/S0012-8252(02)00117-4
Hilgen, F.J., Lourens, L.J., and Van Dam, J.A., 2012. The Neogene period. In Gradstein, F.M., Ogg, J.G., Schmitz, M.D., and Ogg, G.M. (Eds.), The Geologic Time Scale: Oxford (Elsevier), 923-978. doi:10.1016/B978-0-44459425-9.00029-9

Jaeger, J.M., Gulick, S.P.S., LeVay, L.J., Asahi, H., Bahlburg, H., Belanger, C.L., Berbel, G.B.B., Childress, L.B., Cowan, E.A., Drab, L., Forwick, M., Fukumura, A., Ge, S., Gupta, S.M., Kioka, A., Konno, S., März, C.E., Matsuzaki, K.M., McClymont, E.L., Mix, A.C., Moy, C.M., Müller, J., Nakamura, A., Ojima, T., Ridgway, K.D., Rodrigues Ribeiro, F., Romero, O.E., Slagle, A.L., Stoner, J.S., St-Onge, G., Suto, I., Walczak, M.H., and Worthington, L.L., 2014. Methods. In Jaeger, J.M., Gulick, S.P.S., LeVay, L.J., and the Expedition 341 Scientists, Proc. IODP, 341: College Station, TX (Integrated Ocean Drilling Program). doi:10.2204/iodp.proc.341.102.2014

Kamikuri, S., Motoyama, I., and Nishimura, A., 2008. Radiolarian assemblages in surface sediments along longitude $175^{\circ} \mathrm{E}$ in the Pacific Ocean. Mar. Micropaleontol., 69(2):151-172. doi:10.1016/j.marmicro.2008.07.005

Lu, Z., Rickaby, R.E.M., Wellner, J., Georg, B., Charnley, N., Anderson, J.B., and Hensen, C., 2010. Pore fluid modeling approach to identify recent meltwater signals on the west Antarctic Peninsula. Geochem., Geophys., Geosyst., 11(6):Q06017. doi:10.1029/2009GC002949

Matul, A.G., 2011. The recent and quaternary distribution of the radiolarian species Cycladophora davisiana: a biostratigraphic and paleoceanographic tool. Oceanology, 51(2):335-346. doi:10.1134/S0001437011020111

Medlin, L.K., and Priddle, J. (Eds.), 1990. Polar Marine Diatoms: Cambridge (British Antarct. Surv.).

Molnia, B.F., and Hein, J.R., 1982. Clay mineralogy of a glacially dominated, subarctic continental shelf: northeastern Gulf of Alaska. J. Sediment. Petrol., 52(2):515527. doi:10.1306/212F7F90-2B24-11D78648000102C1865D

Pavlis, T.L., Chapman, J.B., Bruhn, R.L., Ridgway, K., Worthington, L.L., Gulick, S.P.S., and Spotila, J., 2012. Structure of the actively deforming fold-thrust belt of the St. Elias orogen with implications for glacial exhumation and three-dimensional tectonic processes. Geosphere, 8(5):991-1019. doi:10.1130/GES00753.1

Plafker, G., 1987. Regional geology and petroleum potential of the northern Gulf of Alaska continental margin. In Scholl, D.W., Grantz, A., and Vedder, J.G. (Eds.), Petroleum Geology Potential of the Continental Margin of Western North America and Adjacent Ocean Basins. Earth Sci. Ser. (N. Y.), 6:229-268.

Plafker, G., Moore, J.C., and Winkler, G.R., 1994. Geology of the southern Alaska margin. In Plafker, G., and Berg, H.C. (Eds.), The Geology of North America (Vol. G): The Geology of Alaska: Boulder, CO (Geol. Soc. Am.), 389449.

Powell, R.D., and Cooper, J.M., 2002. A glacial sequence stratigraphic model for temperate, glaciated continental shelves. In Dowdeswell, J.A., and Ó'Cofaigh, C. (Eds.), Glacier-Influenced Sedimentation on High-Latitude Continental Margins. Geol. Soc. Spec. Publ., 203:215-244. doi:10.1144/GSL.SP.2002.203.01.12 
Saffer, D.M., and McKiernan, A.W., 2009. Evaluation of in situ smectite dehydration as a pore water freshening mechanism in the Nankai Trough, offshore southwest Japan. Geochem., Geophys., Geosyst., 10(2):Q02010. doi:10.1029/2008GC002226

Sancetta, C., 1982. Distribution of diatom species in surface sediments of the Bering and Okhotsk Seas. Micropaleontology, 28(3):221-257. doi:10.2307/1485181

Schubert, C.J., and Calvert, S.E., 2001. Nitrogen and carbon isotopic composition of marine and terrestrial organic matter in Arctic Ocean sediments: implications for nutrient utilization and organic matter composition. Deep-Sea Res., Part I, 48(3):789-810. doi:10.1016/ S0967-0637(00)00069-8

Sisson, V.B., Poole, A.R., Harris, N.R., Cooper Burner, H., Pavlis, T.L., Copeland, P., Donelick, R.A., and McClelland, W., 2003. Geochemical and geochronologic constraints for genesis of a tonalite-trondhjemite suite and associated mafic intrusive rocks in the eastern Chugach Mountains, Alaska: a record of ridge-transform subduction. In Sisson, V.B., Roeske, S.M., and Pavlis, T.L. (Eds.), Geology of a Transpressional Orogen Developed During Ridge-Trench Interaction Along the North Pacific Margin: Spec. Pap.—Geol. Soc. Am., 371:293-326. doi:10.1130/ 0-8137-2371-X.293

Tittman, J., 1986. Geophysical Well Logging: Orlando (Academic Press).

Torres, M.E., Teichert, B.M.A., Tréhu, A.M., Borowski, W., and Tomaru, H., 2004. Relationship of pore water freshening to accretionary processes in the Cascadia margin: fluid sources and gas hydrate abundance. Geophys. Res. Lett., 31:L22305. doi:10.1029/2004GL021219

von Breymann, M.T., Brumsack, H., and Emeis, K.C., 1992. Depositional and diagenetic behavior of barium in the
Japan Sea. In Pisciotto, K.A., Ingle, J.C., Jr., von Breymann, M.T., Barron, J., et al., Proc. ODP, Sci. Results, 127/ 128 (Pt. 1): College Station, TX (Ocean Drilling Program), 651-665. doi:10.2973/odp.proc.sr.1271281.168.1992

Walinsky, S.E., Prahl, F.G., Mix, A.C., Finney, B.P., Jaeger, J.M., and Rosen, G.P., 2009. Distribution and composition of organic matter in surface sediments of coastal southeast Alaska. Cont. Shelf Res., 29(13):1565-1579. doi:10.1016/j.csr.2009.04.006

Willems, B.A., 2009. Quaternary glacial and climatic history of southern Alaska using high-resolution seismic reflection records [Ph.D. dissert.]. Northern Illinois Univ., DeKalb.

Worthington, L.L., Gulick, S.P.S., and Pavlis, T.L., 2008. Identifying active structures in the Kayak Island and Pamplona zones: implications for offshore tectonics of the Yakutat microplate, Gulf of Alaska. In Freymueller, J.T., Haeussler, P.J., Wesson, R.L., and Ekström, G. (Eds.), Active Tectonics and Seismic Potential of Alaska. Geophys. Monogr., 179:257-268. doi:10.1029/179GM14

Worthington, L.L, Gulick, S.P.S., and Pavlis, T.L., 2010. Coupled stratigraphic and structural evolution of a glaciated orogenic wedge, offshore St. Elias orogen, Alaska. Tectonics, 29:TC6013-TC6039. doi:10.1029/ 2010TC002723

Zellers, S.D., 1995. Foraminiferal sequence biostratigraphy and seismic stratigraphy of a tectonically active margin: the Yakataga Formation, northeastern Gulf of Alaska. Mar. Micropaleontol., 26(1-4):255-271. doi:10.1016/ 0377-8398(95)00031-3

Publication: 22 November 2014 MS 341-106 
Figure F1. A. Uninterpreted (top) and interpreted (bottom) STEEP09 seismic line, showing mappable horizons through the Bering shelf region. Targets for Site U1420 include Horizon H1, locally an angular unconformity at the base of glacial erosion surfaces, and Horizon H2, which marks the cessation of movement on the Pamplona zone structures beneath the Bering Trough. Colored lines (H1-H5) are regional horizons interpreted throughout the study area. Black horizons (A-F) are interpreted locally to define glacial depositional sequences in the upper $2 \mathrm{~s}$ of the record. $\mathrm{VE}=$ vertical exaggeration assuming $1500 \mathrm{~m} / \mathrm{s}$ sound velocity. BT1-BT4 = fault structures. B. Perspective view of the Bering Trough region, showing locations of the trough relative to active structures of the Pamplona zone. YAK-NA = Yakutat-North America. Modified from Worthington et al. (2010).
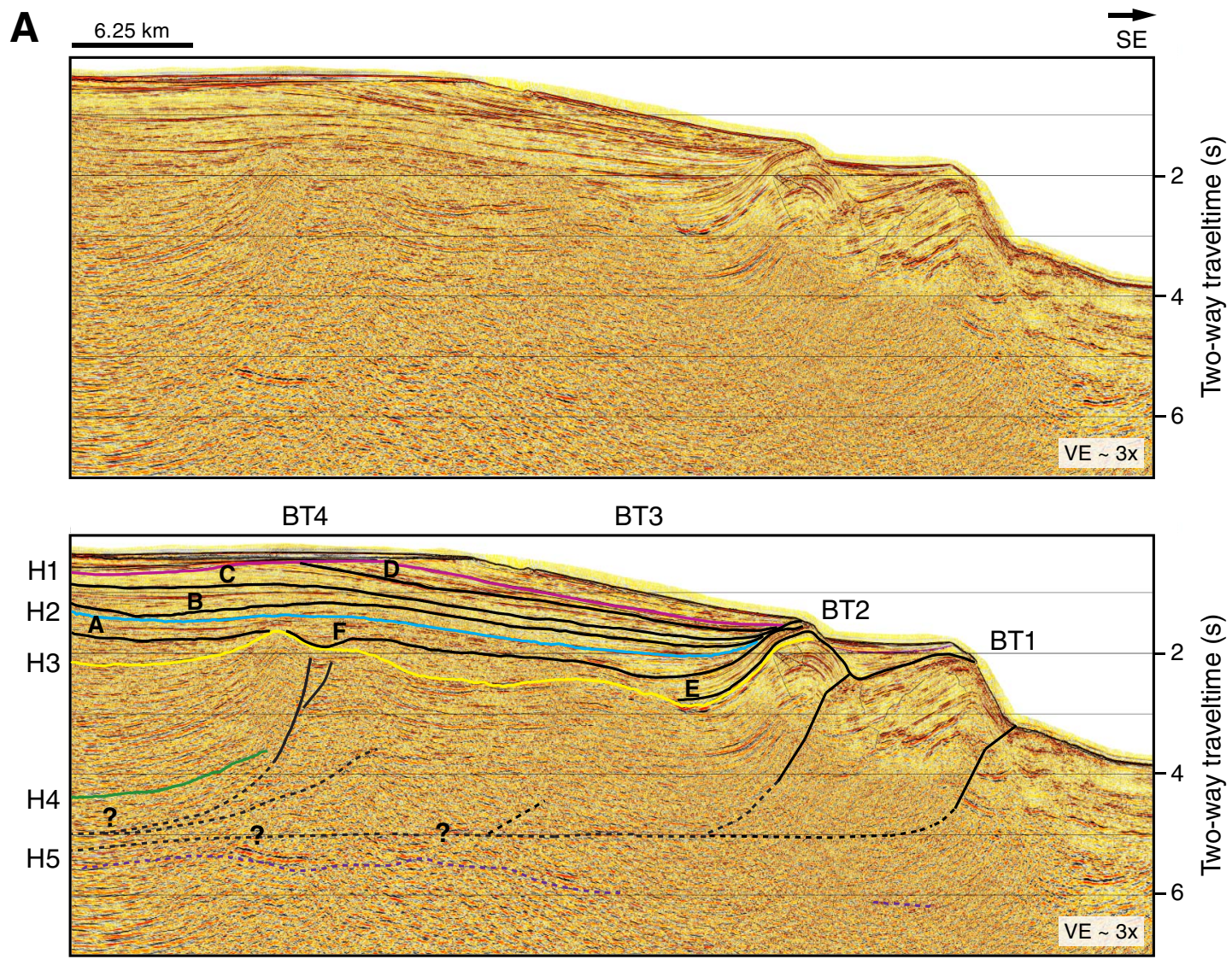

B

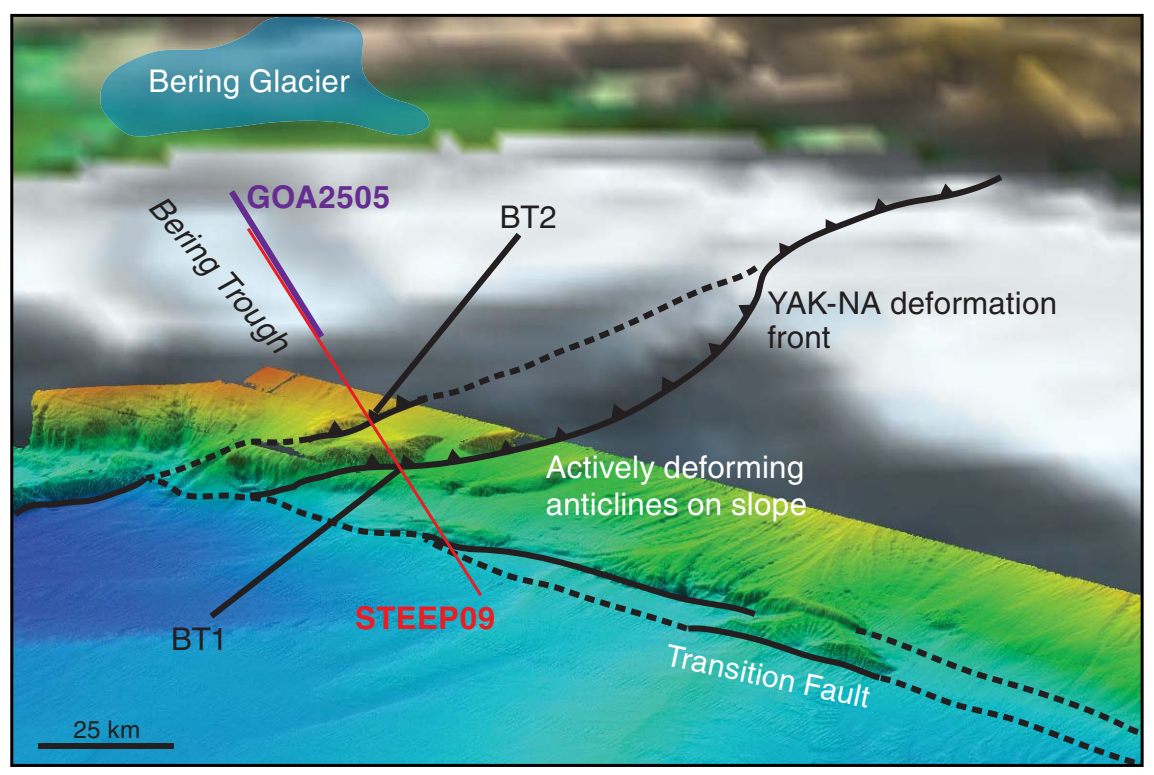


Figure F2. Uninterpreted (top) and interpreted (bottom) GOA2505 seismic section. Interpreted section shows Structures BT4 and BT5 and key horizons. See Figure F1 for explanation of horizon delineation. VE = vertical exaggeration $1500 \mathrm{~m} / \mathrm{s}$ velocity. Proposed drilling depths for Sites U1420 and U1421 are shown. From Worthington et al. (2010).
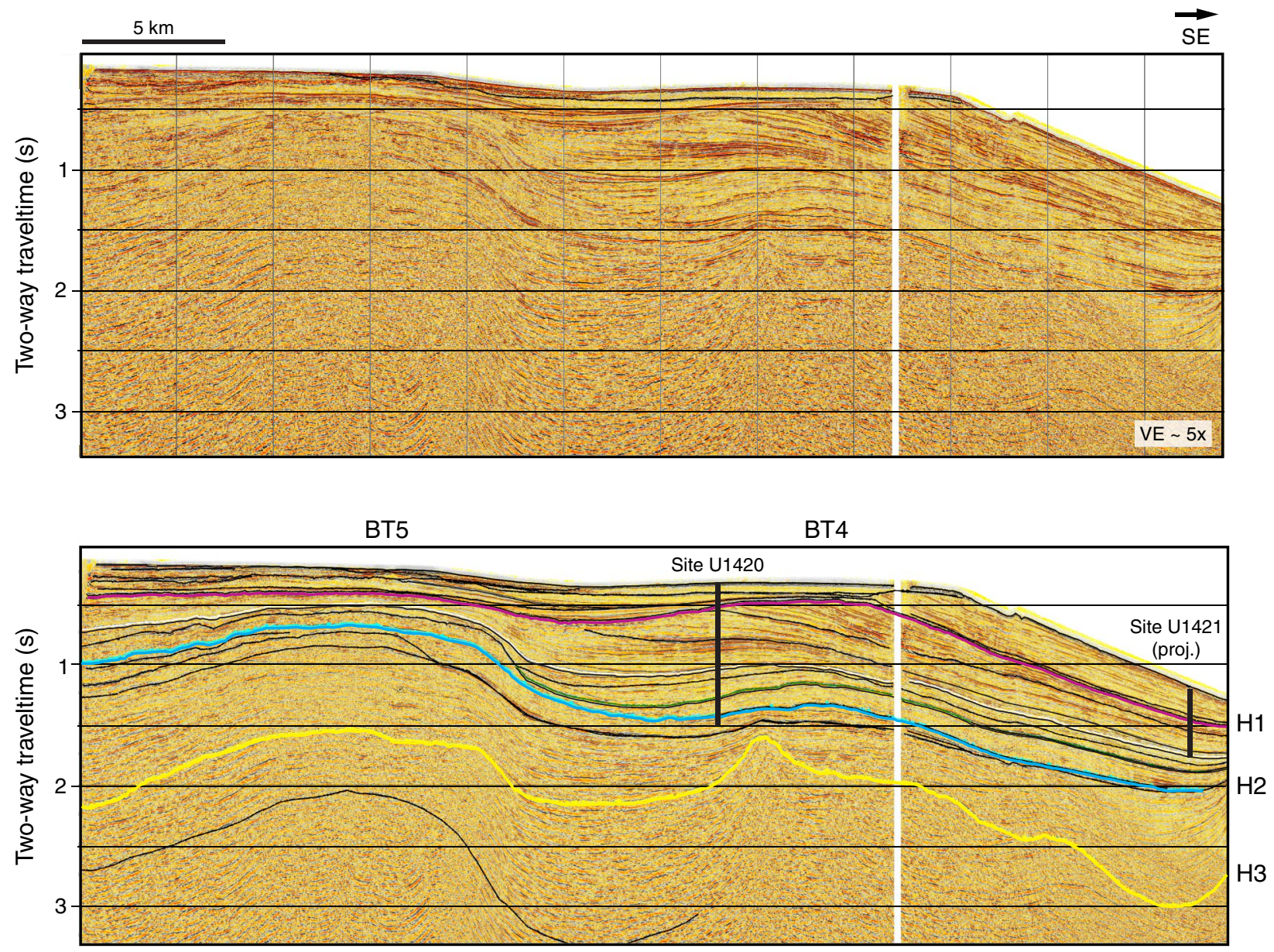
Figure F3. Hypothetical lithofacies motifs and facies succession for a mid-shelf location, such as Site U1420, that may experience the full range of glacier ice advance-retreat cycles. Lithofacies are depicted using particlesize variations. Inferred depositional environment includes a continuum curve. Sediment accumulation rate is also inferred. IRD = ice-rafted debris. Modified after Powell and Cooper (2002).

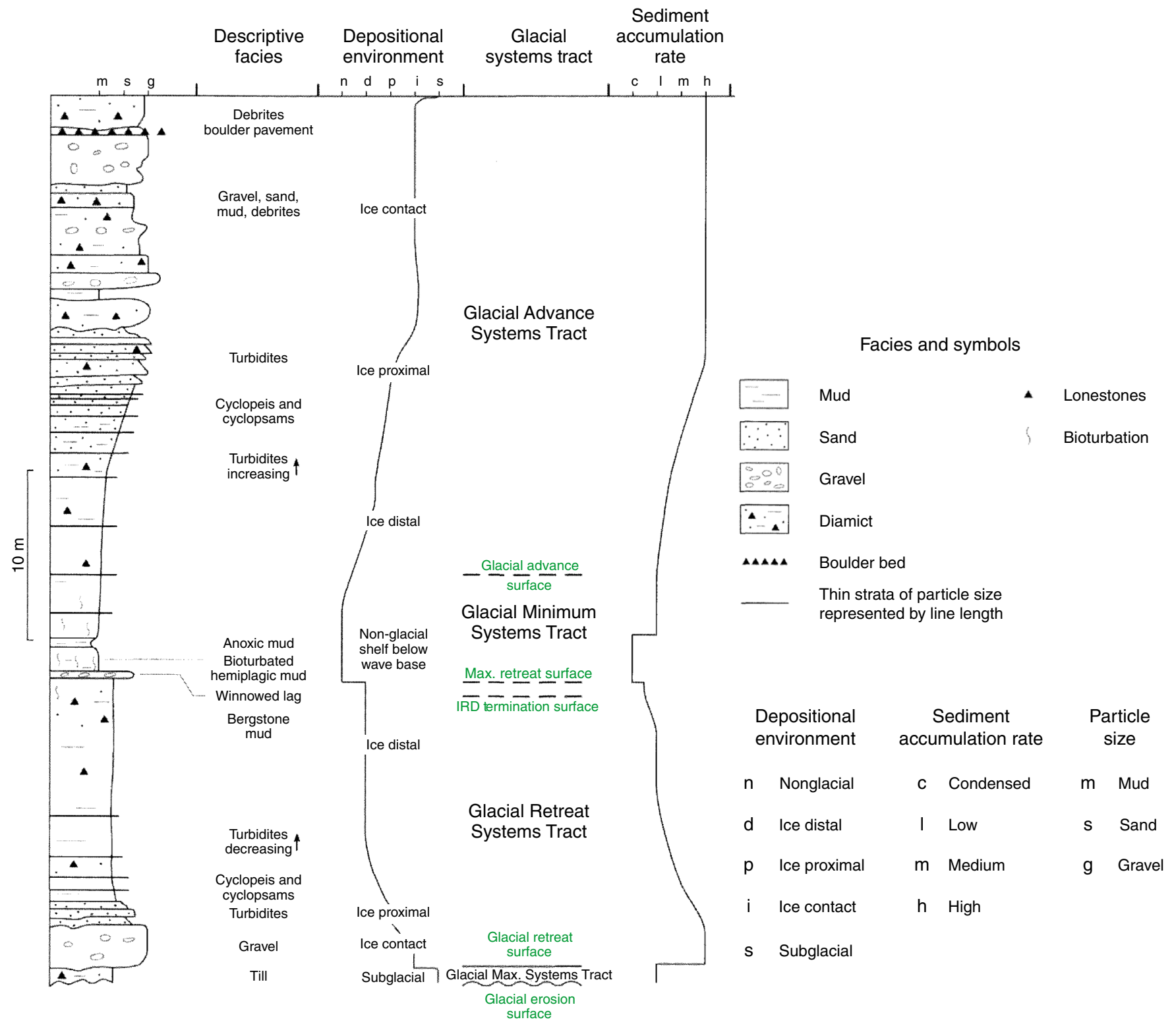


Figure F4. Core recovery, Site U1420.

\section{Site U1420}

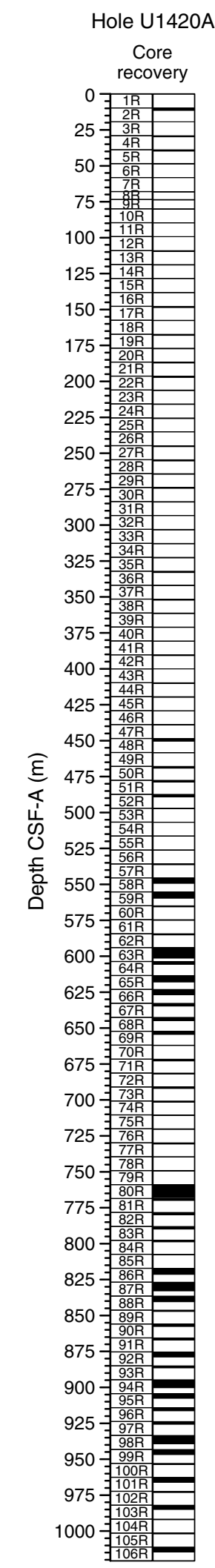


Figure F5. Hole summary, Hole U1420A. Volcanic grain abundance: $1=$ trace, $2=$ volcaniclastic bearing, $3=$ volcaniclastic rich, $4=$ ash. GRA = gamma ray attenuation.
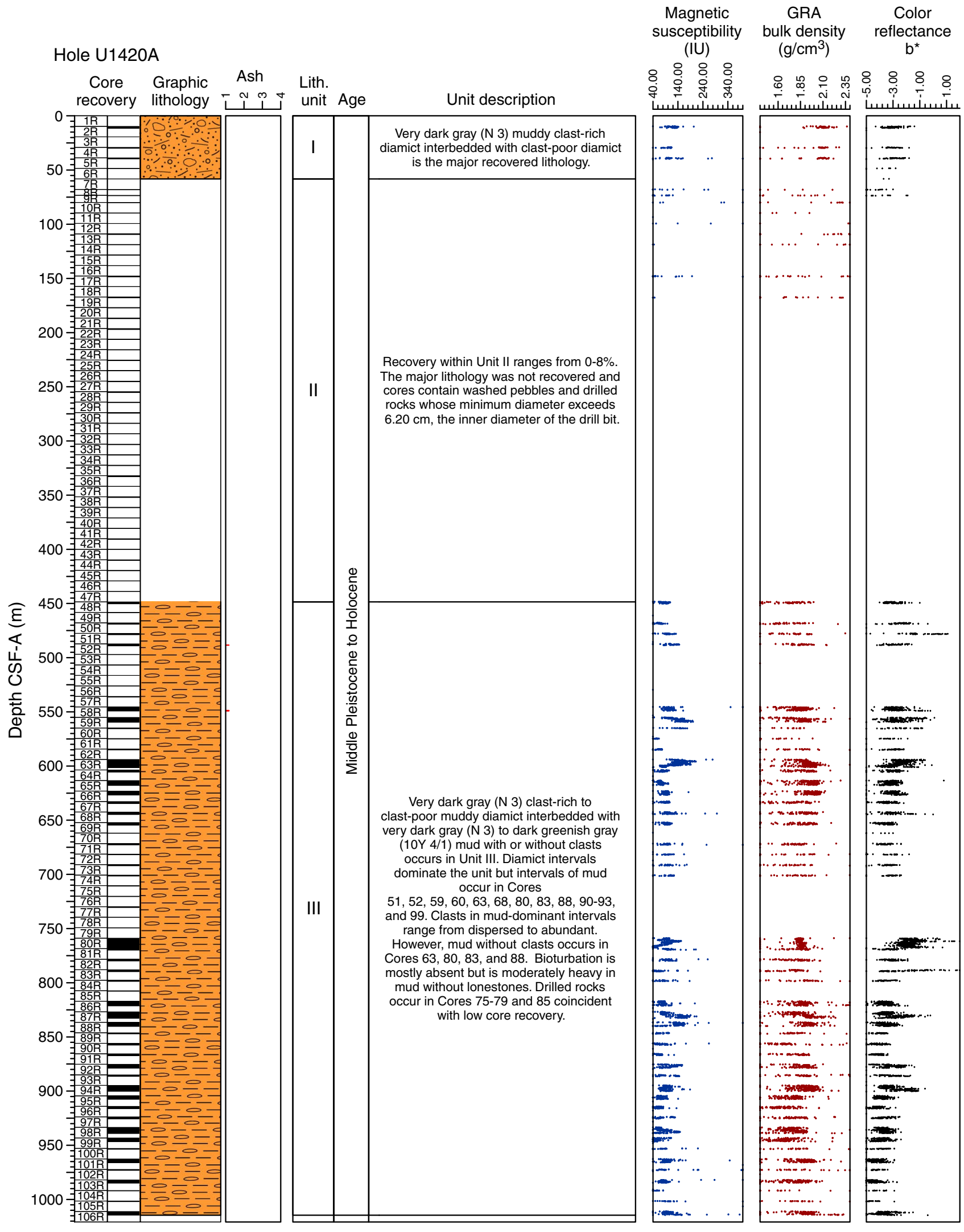
Figure F6. Examples of lithofacies of Site U1420. A. Dark gray (N 4) massive mud with lonestones (Facies F1a; interval 341-U1420A-63R-1A, 98-106 cm). B. Dark greenish gray (10Y 4/1) massive mud without lonestones (Facies F1b; interval 341-U1420A-83R-1A, 66-72 cm). C. Heavily bioturbated mud without lonestones (Facies F1b; interval 341-U1420A-63R-2A, 3-11 cm). D. Transition from clast-rich diamict (Facies F4f; interval 341U1420A-93R-1A, 53-69 cm) to clast-poor diamict (Facies F4e; interval 93R-1A, 69-77 cm). E. Clast-rich diamict with shell fragments (arrows) (Facies F4f; interval 341-U1420A-94R-2, 50-58 cm). F. Mud with biosilica and dispersed clasts (Facies F5b; interval 341-U1420A-59R-2A, 119-127 cm). G. Carbonate-bearing, clast-rich diamict with sandy mud matrix (Facies F5c; interval 341-U1420A-71R-1A, 79-85 cm). H. Intercalated dark gray and very dark gray clast-rich diamict (Facies F4f; interval 341-U1420A-98R-3A, 26-47 cm).

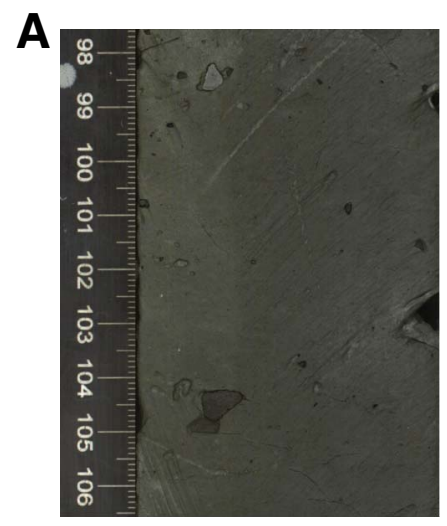

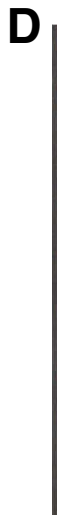
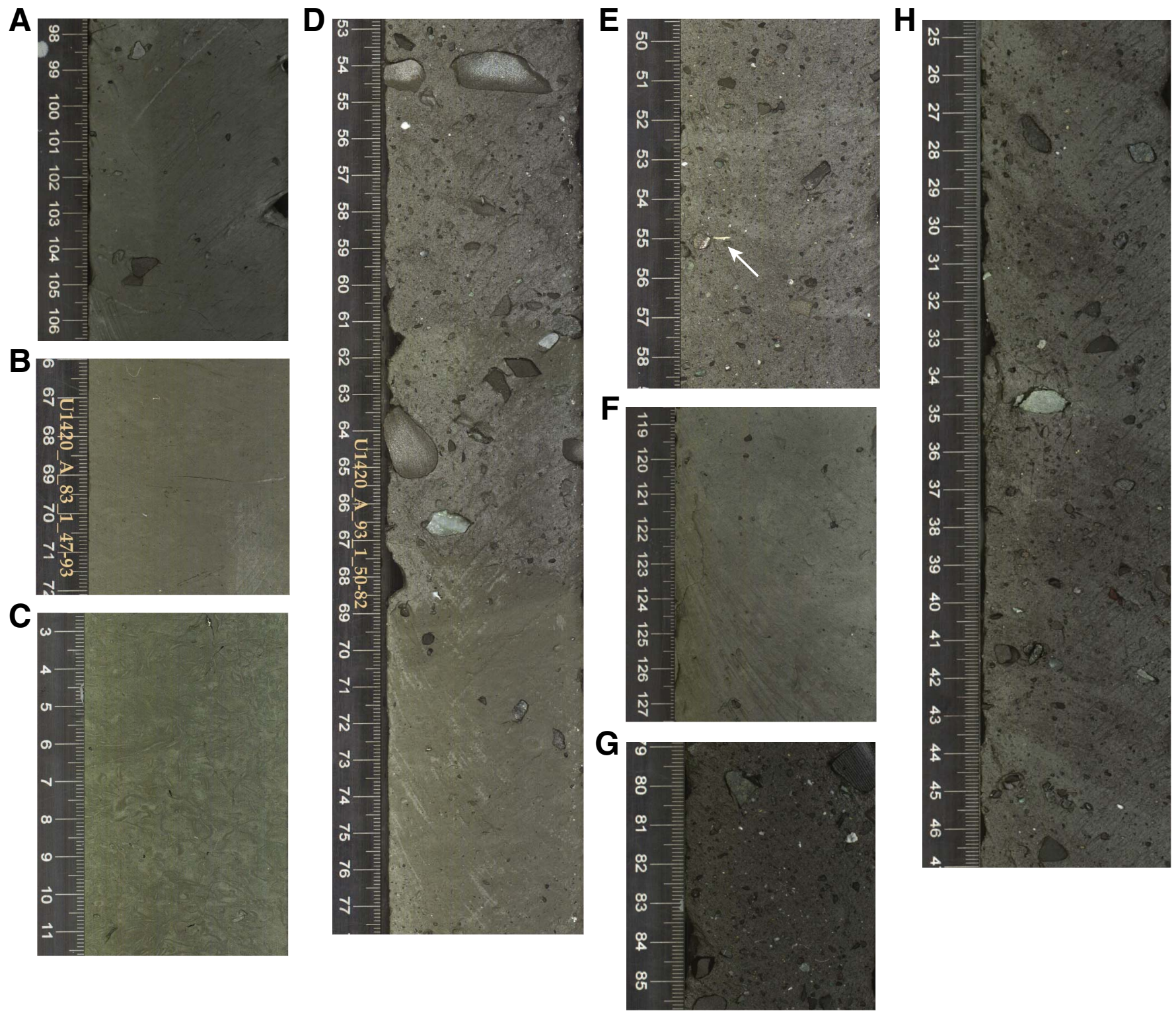
Figure F7. Examples of clasts, drilled rocks, and macrofossils, Site U1420. A. Parallel oriented clasts in diamict (interval 341-U1420A-93R-1A, 50-58 cm). B. Metasedimentary clast with veins of pyrite (interval 341-U1420A95R-3A, 13-15 cm). C. Drilled sandstone clast (interval 341-U1420A-11R-1A, 1-9 cm). D. Drilled metagraywacke clast (interval 341-U1420A-10R-1A, 1-9 cm). E. Drilled volcanic breccia clast (interval 341-U1420A-20R1A, 4-9 cm). F. Drilled basalt clast (interval 341-U1420A-10R-1A, 10-19 cm). G. Drilled brecciated rhyolite clasts likely from a single boulder (interval 341-U1420A-22R-1A, 59-88 cm). H, I. Mollusk and gastropod fossils (intervals 341-U1420A-58R-1A, 33-35 cm, and 87R-3A, $77 \mathrm{~cm}$ ).

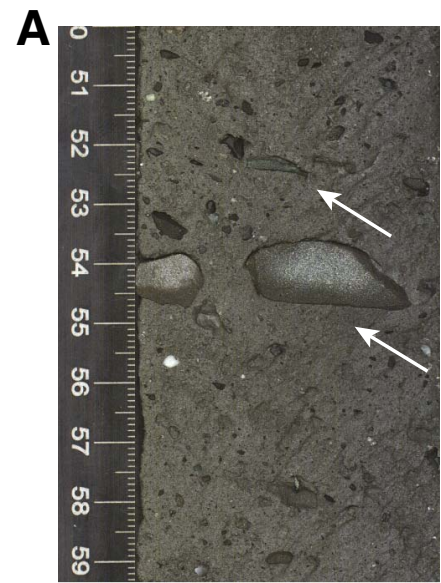

B

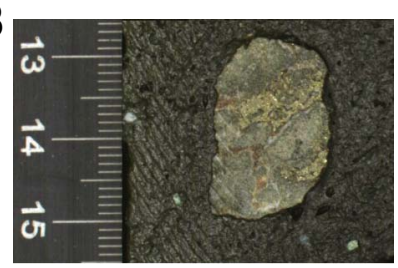

C

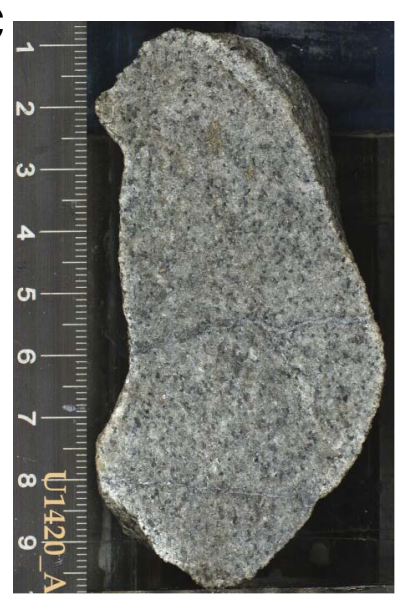

D

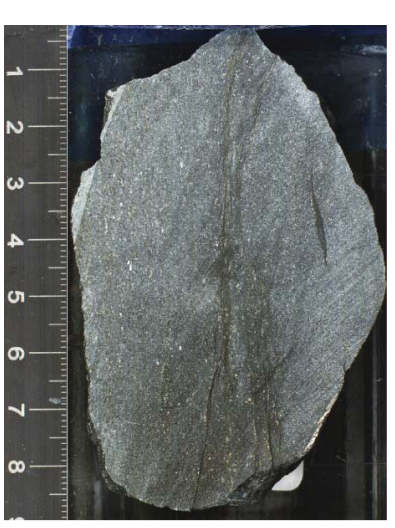

E

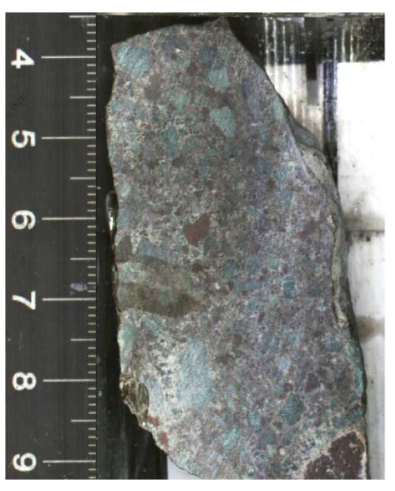

$F$

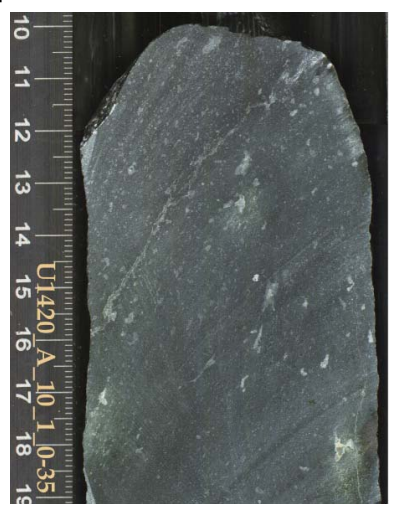

G

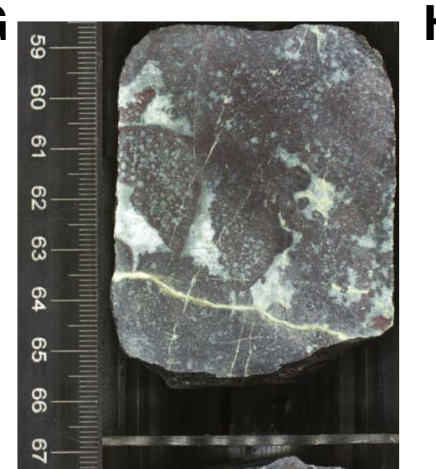

9 春

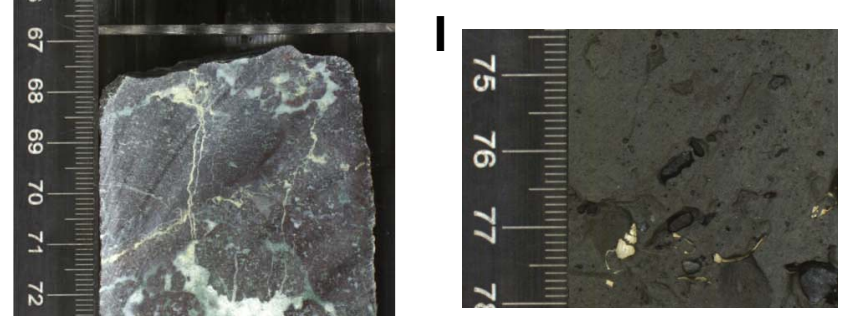

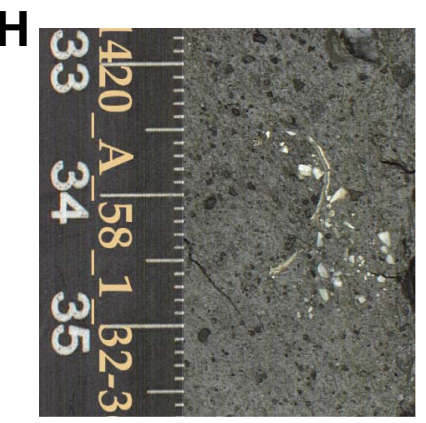


Figure F8. Ternary diagram showing average abundance of the main lithology types of clasts larger than $2 \mathrm{~mm}$ in Hole U1420A. $\mathrm{M}=$ metamorphic, $\mathrm{I}$ = igneous, $\mathrm{S}$ = sedimentary.

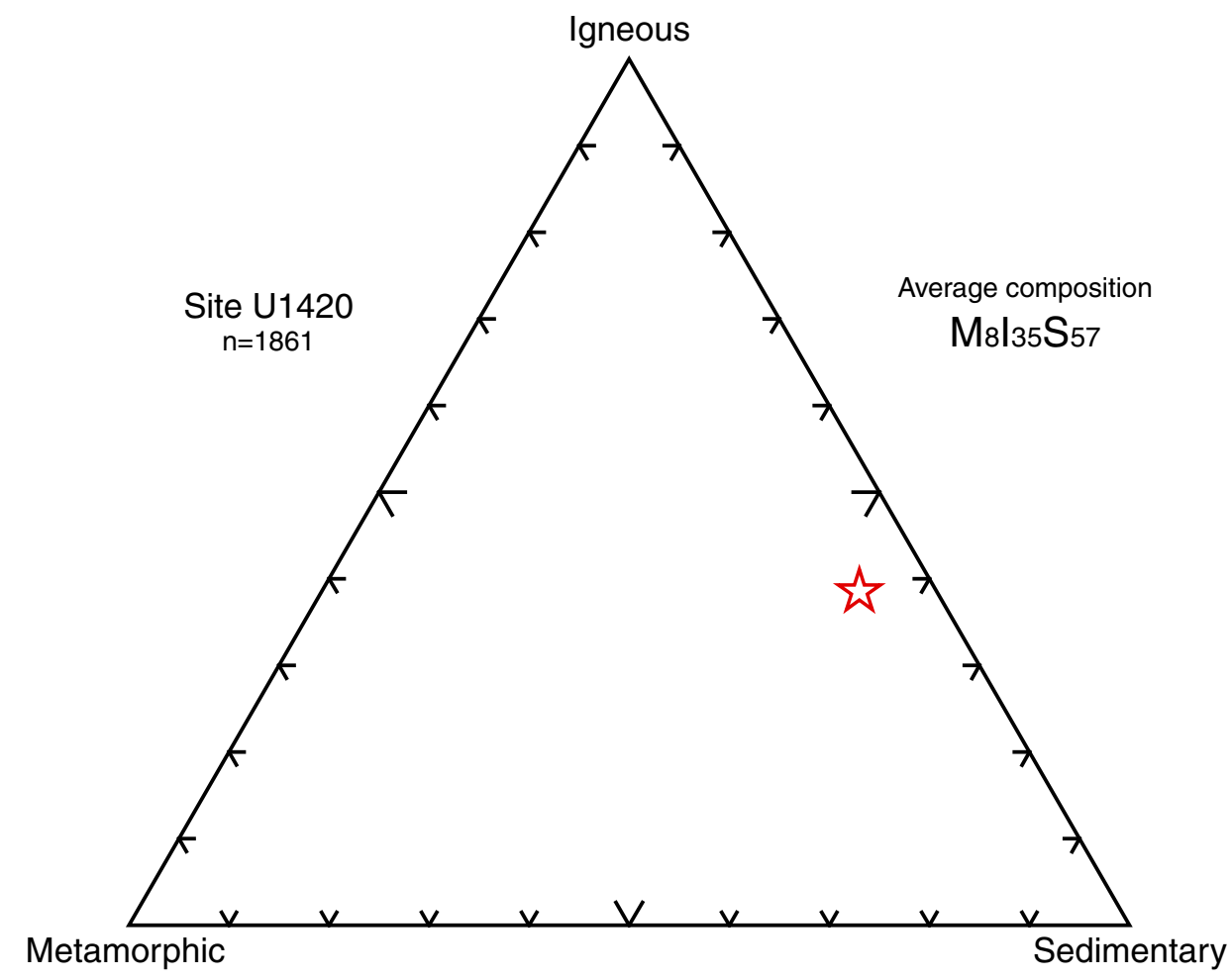


Figure F9. A. X-ray powder diffraction patterns, Hole U1420A. Bulk mineralogy is consistent downhole, although minor changes in intensity occur in various peaks. (Continued on next page.)

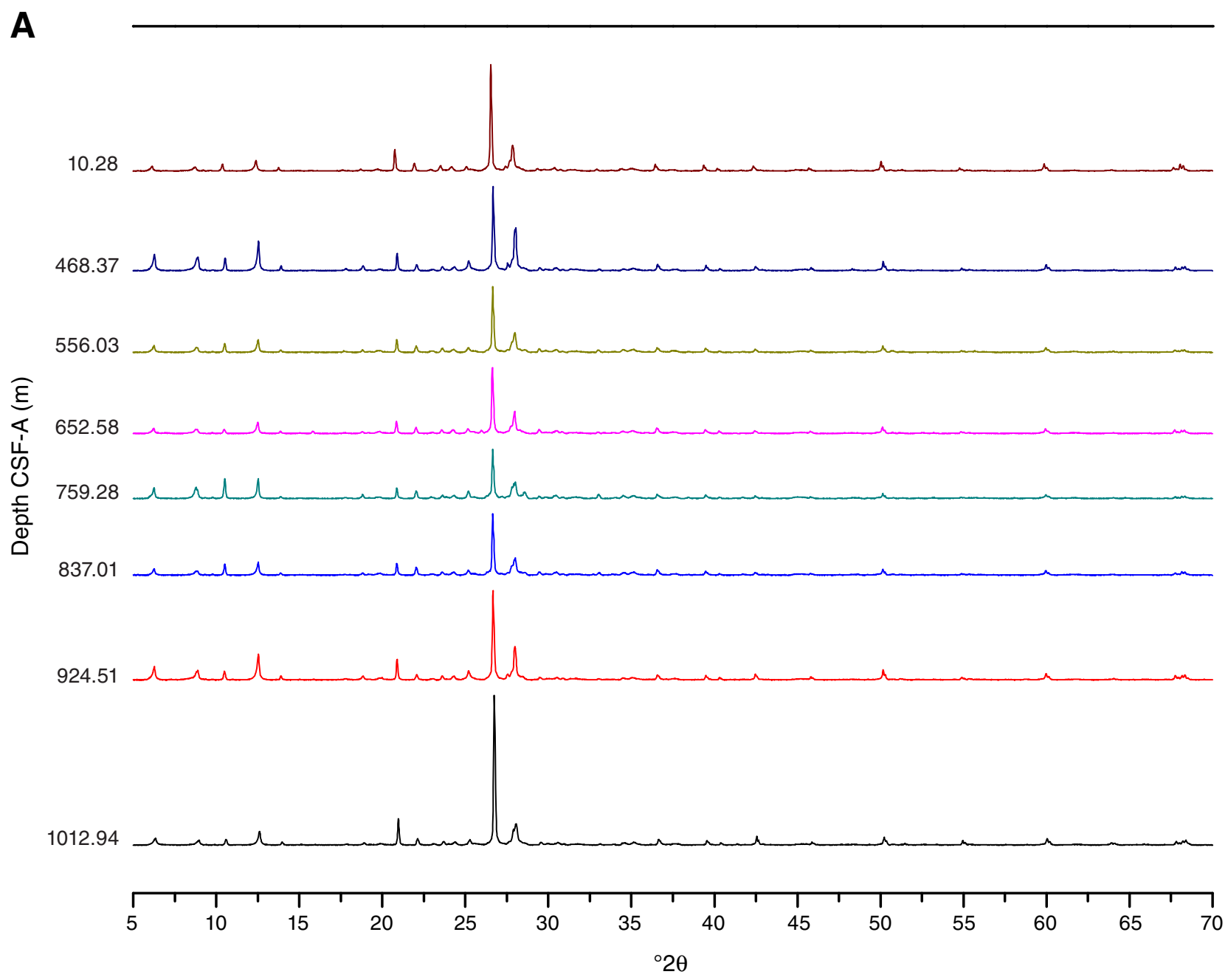


Figure F9 (continued). B. Comparative X-ray diffraction patterns from $4^{\circ}$ to $24^{\circ} 2 \theta$. Scans show the downhole samples before (left) and after (right) glycolization treatment.

B
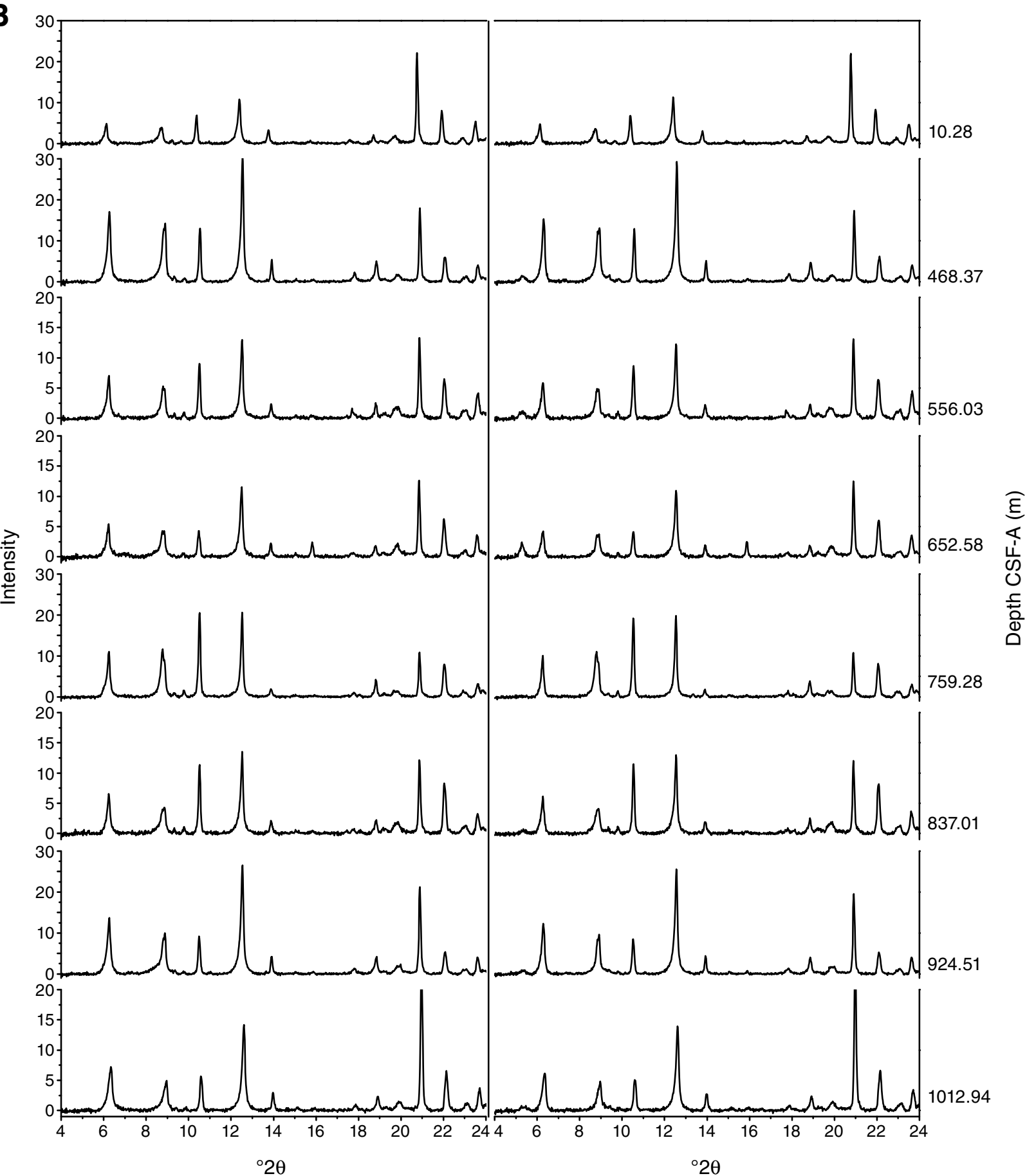
Figure F10. Schematic diagram of lithostratigraphic units and major lithologies, Hole U1420A. Diamonds = intervals of mud or silty mud with high bioturbation. With the exception of core recovery, downcore profiles represent the occurrence of a described lithologic feature. Because of low core recovery $(<10 \%)$, the distribution of lithostratigraphic units between 60 and 450, 500 and 540, and 710 and $750 \mathrm{~m} \mathrm{CSF-A} \mathrm{is} \mathrm{not} \mathrm{shown.}$

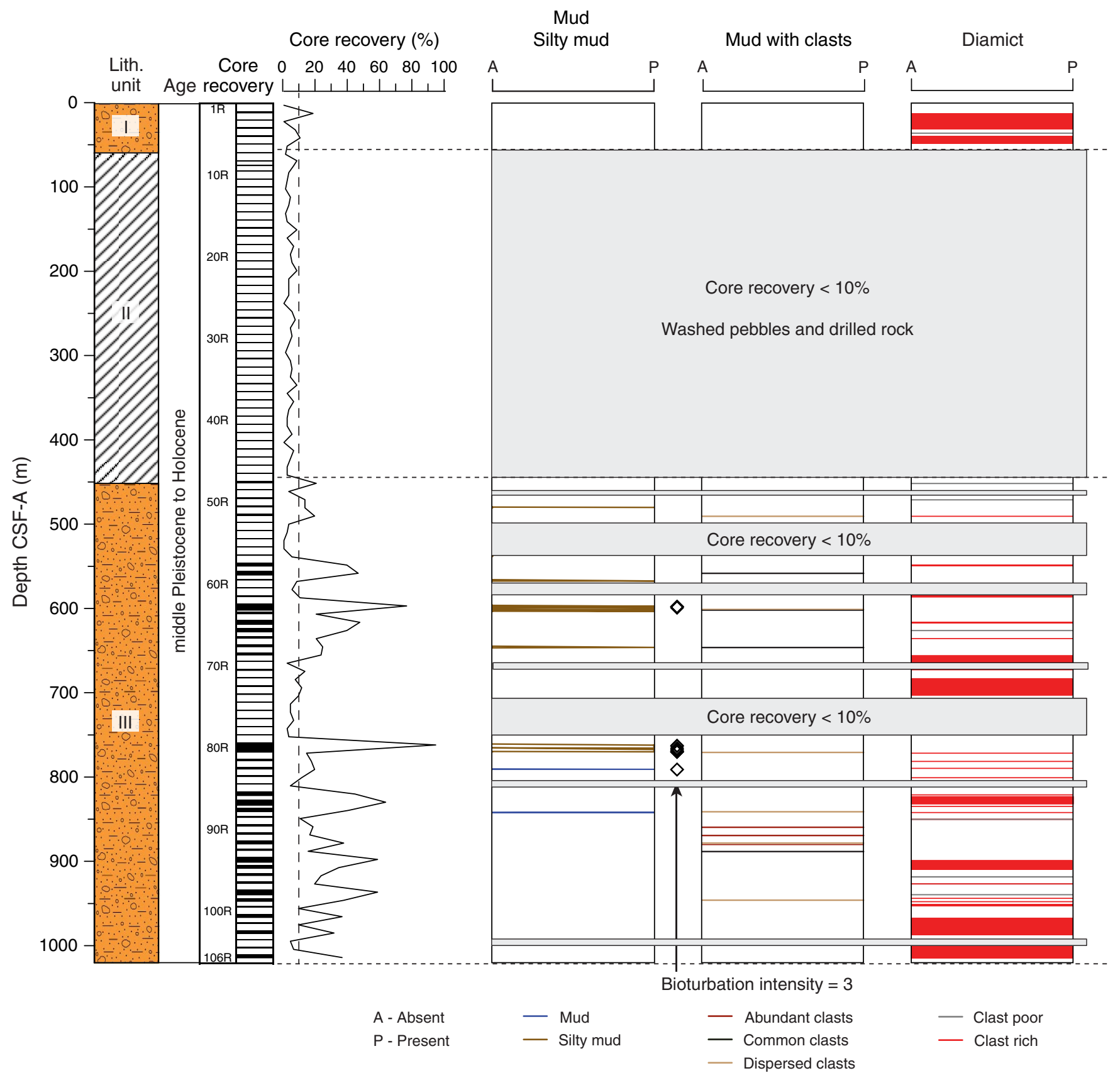


Figure F11. Integration of lithostratigraphic observations, physical properties measurements, downhole logging, and seismic data, Site U1420. Two-way traveltime calculated from $P$-wave caliper (PWC) measurements and sonic log velocities. Velocities extrapolated using downhole sonic $\log$ values where no data were available.

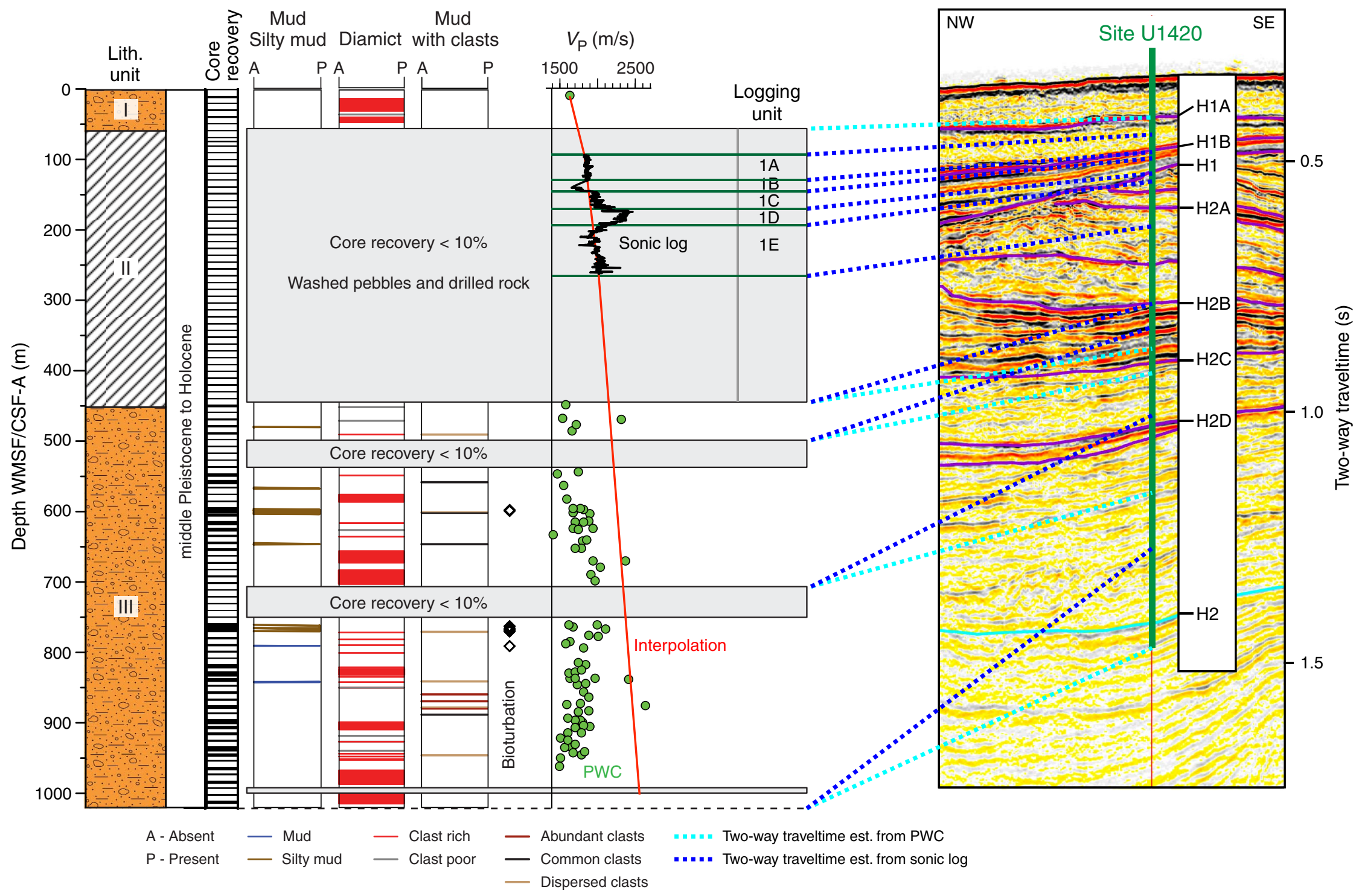


Figure F12. Abundance and preservation of diatoms, radiolarians, and planktonic and benthic foraminifers, Site U1420. Abundance: $\mathrm{D}=$ dominant, $\mathrm{A}=$ abundant, $\mathrm{C}=$ common, $\mathrm{F}=\mathrm{few}, \mathrm{R}=$ rare, $\mathrm{B}=$ barren. Preservation: $\mathrm{VG}=$ very good, $\mathrm{G}=$ good, $\mathrm{M}=$ moderate, $\mathrm{P}=$ poor.

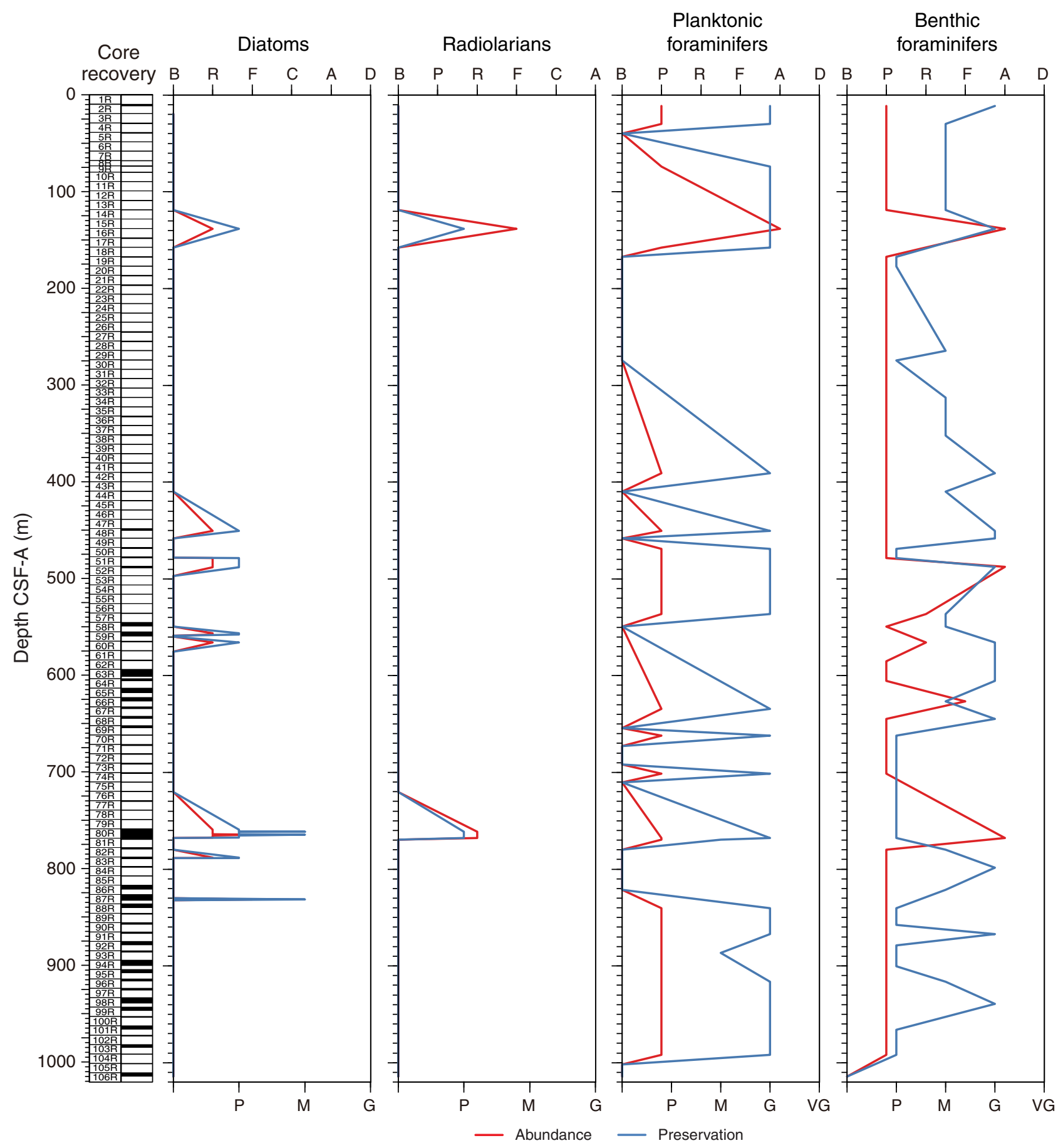


Figure F13. Relative rank abundance of planktonic foraminifers Globigerina bulloides and Globigerina umbilicata integrate, Site U1420. Abundance: $\mathrm{D}=$ dominant, $\mathrm{A}=$ abundant, $\mathrm{F}=\mathrm{few}, \mathrm{R}=$ rare, $\mathrm{P}=$ present.

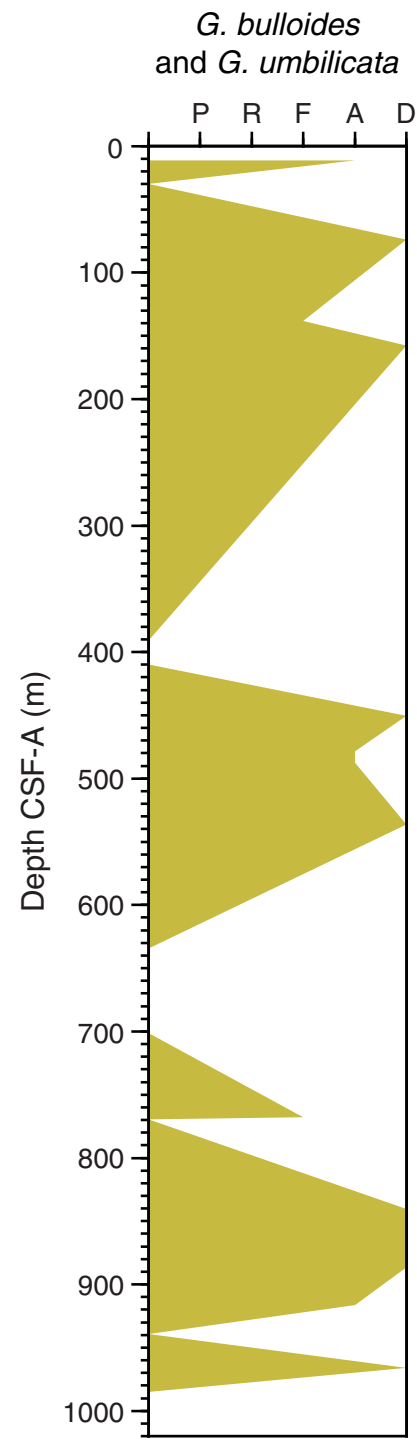


Figure F14. Relative rank abundance of benthic foraminifers Elphidium spp., Islandiella norcrossi, Epistominella pacifica, and Uvigerina spp., Site U1420. Abundance: $\mathrm{D}=$ dominant, $\mathrm{A}=$ abundant, $\mathrm{F}=\mathrm{few}, \mathrm{R}=\mathrm{rare}, \mathrm{P}=$ present.

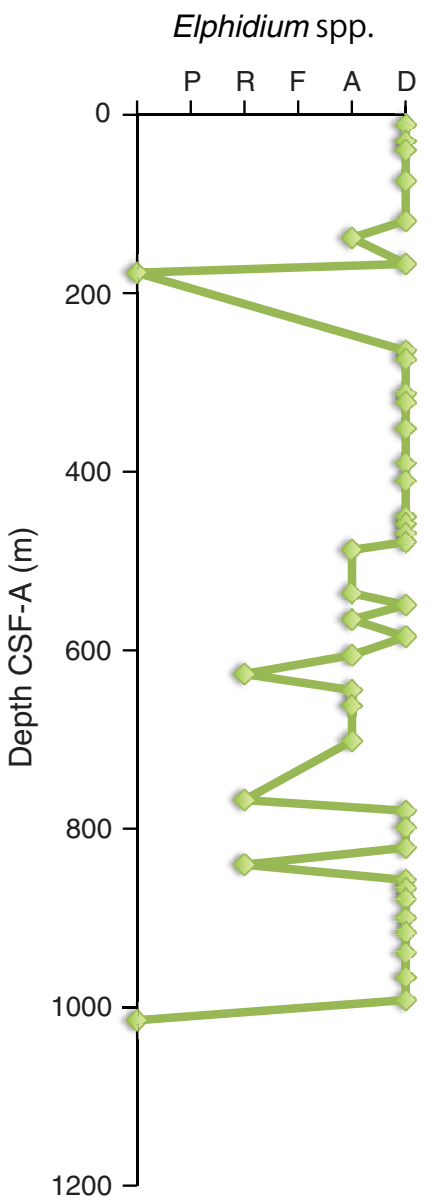

Isandiella norcrossi

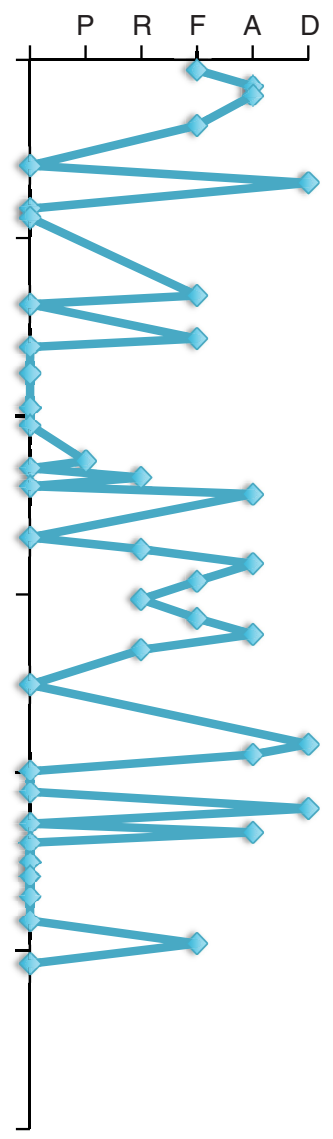

Epistominella pacifica

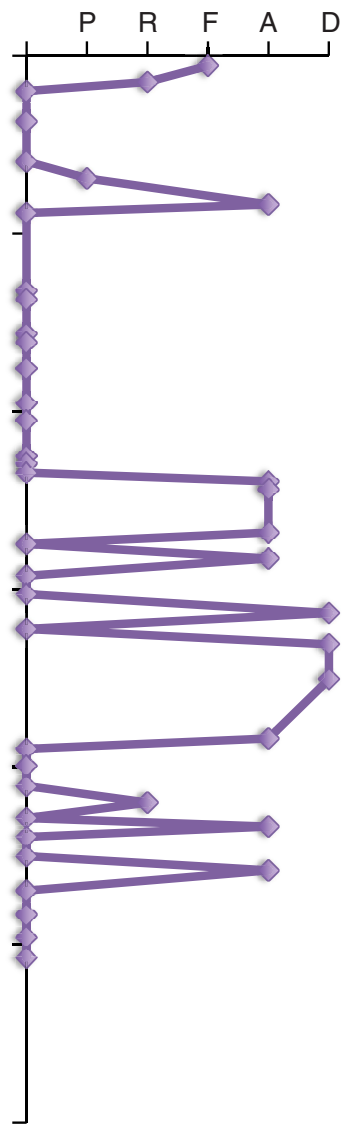

Uvigerina spp.

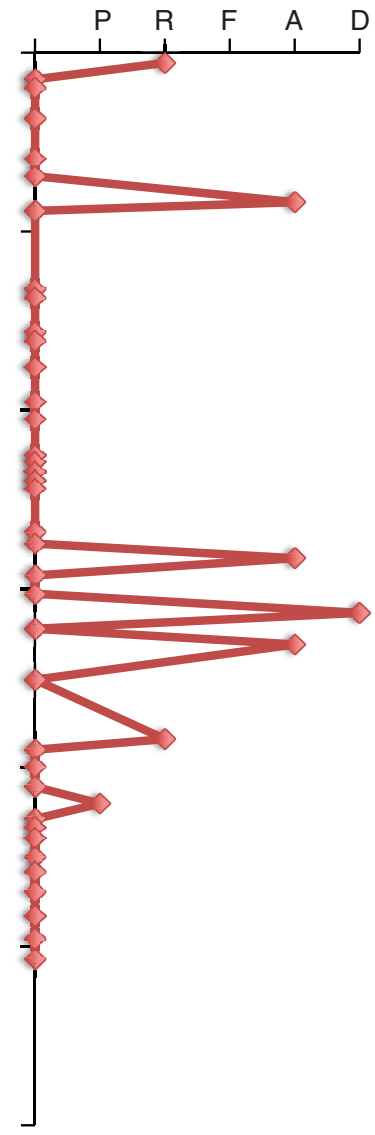


Figure F15. Dissolved chemical concentrations and headspace gas, Hole U1420A. A. Alkalinity. B. pH. C. Sulfate. D. Ammonium. E. Bromide. F. Methane. G. Ethane. H. Silica. I. Salinity. J. Chloride. K. Sodium. Full details of Lithology column are shown in Figure F6 (see "Lithostratigraphy").

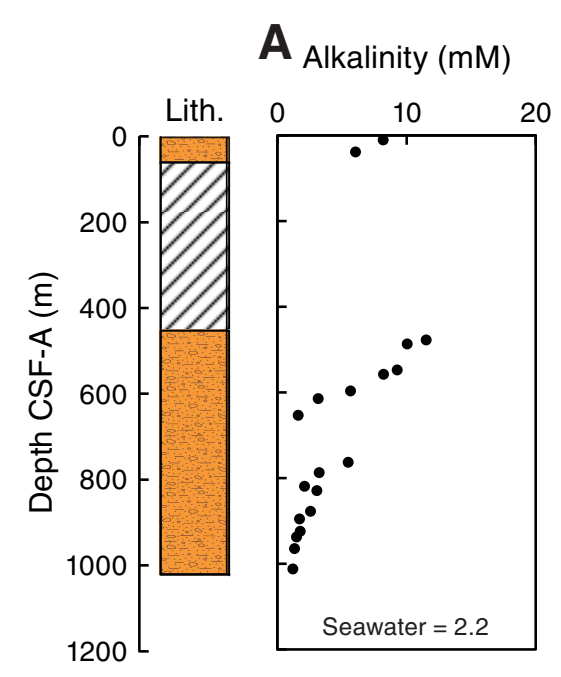

B

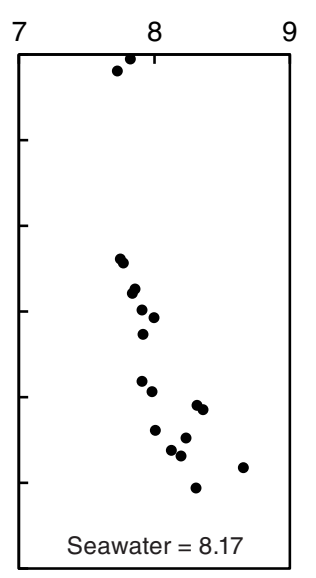

$\mathbf{F}_{\text {Methane (ppmv) }}$
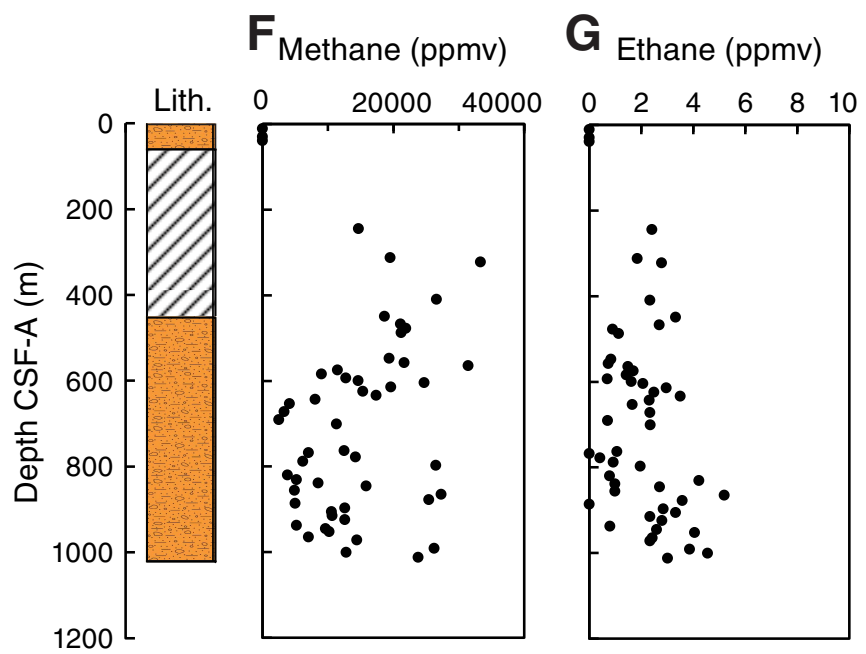

C Sulfate (mM)

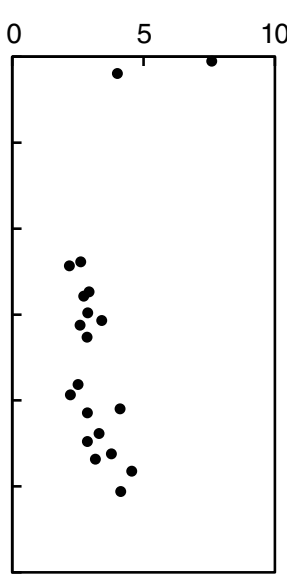

$\mathbf{D}_{\text {Ammonium (mM) }}$
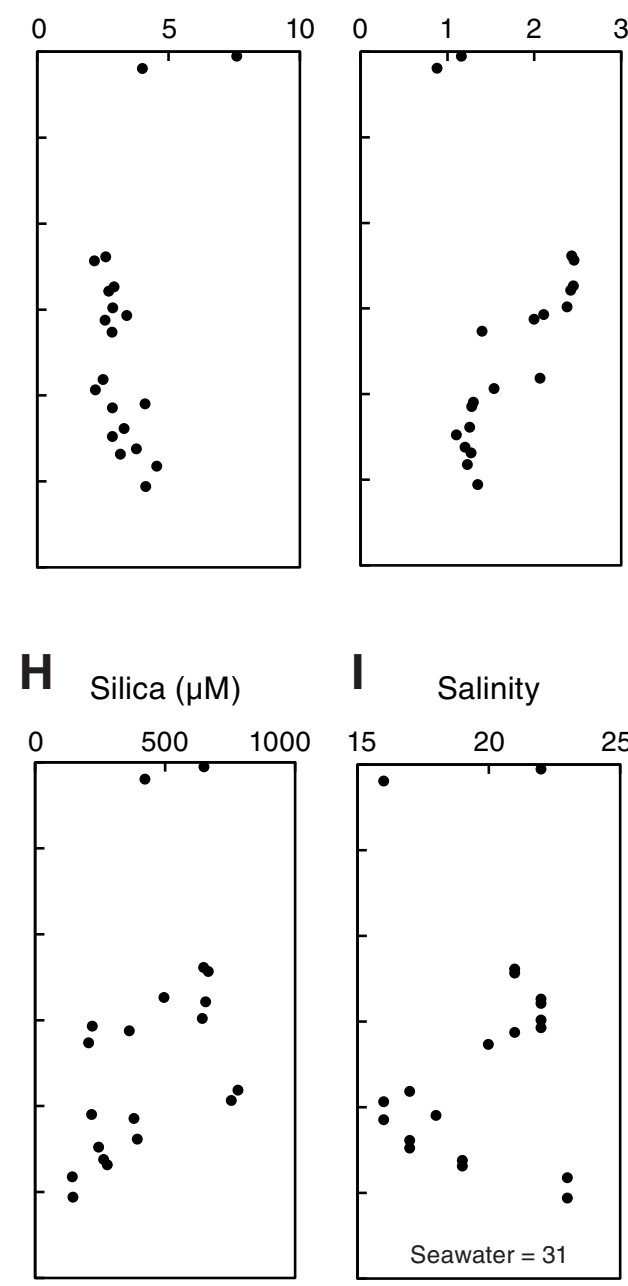

E Bromide (mM)

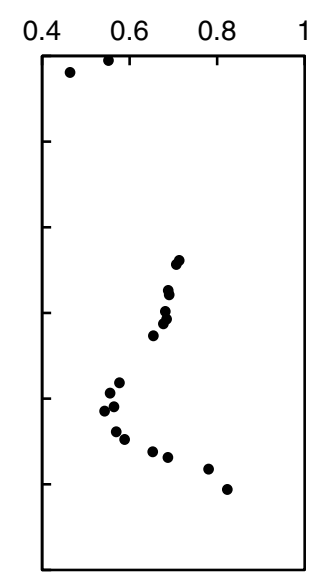

$\mathbf{J}_{\text {Chloride (mM) }} \mathbf{K}_{\text {Sodium (mM) }}$
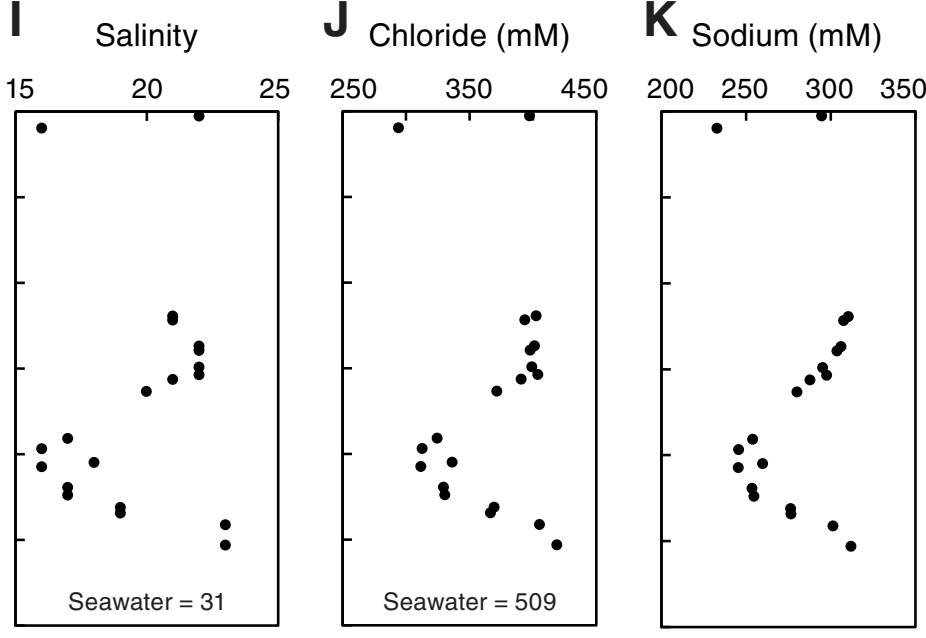
Figure F16. Dissolved chemical concentrations, Hole U1420A. A. Calcium. B. Potassium. C. Magnesium. D. Lithium. E. Boron. F. Barium. G. Strontium. H. Iron. I. Manganese. J. Phosphate. Full details of Lithology column are shown in Figure F6 (see "Lithostratigraphy").
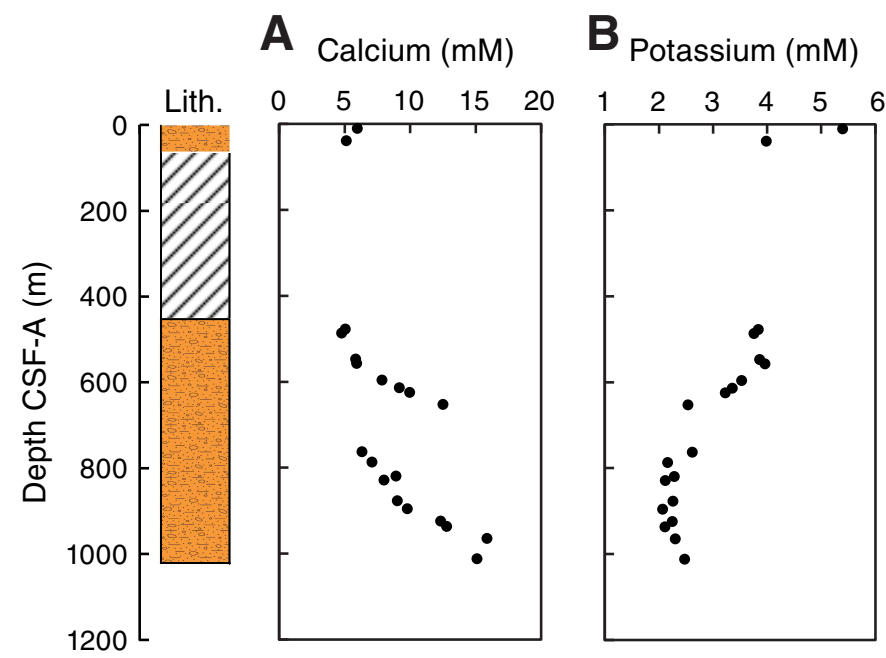

C Magnesium (mM)

D Lithium $(\mu \mathrm{M})$
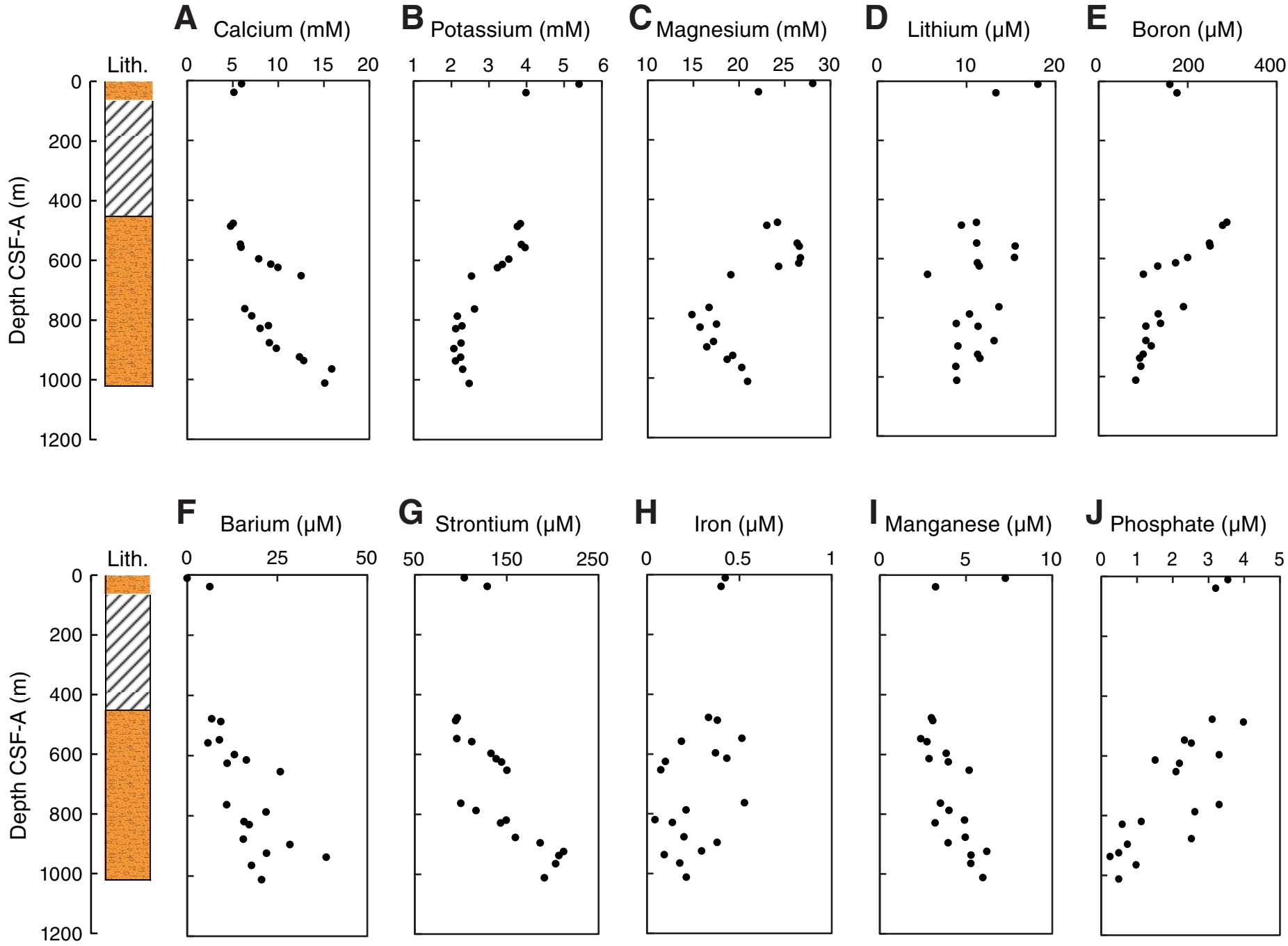

I Manganese $(\mu \mathrm{M})$
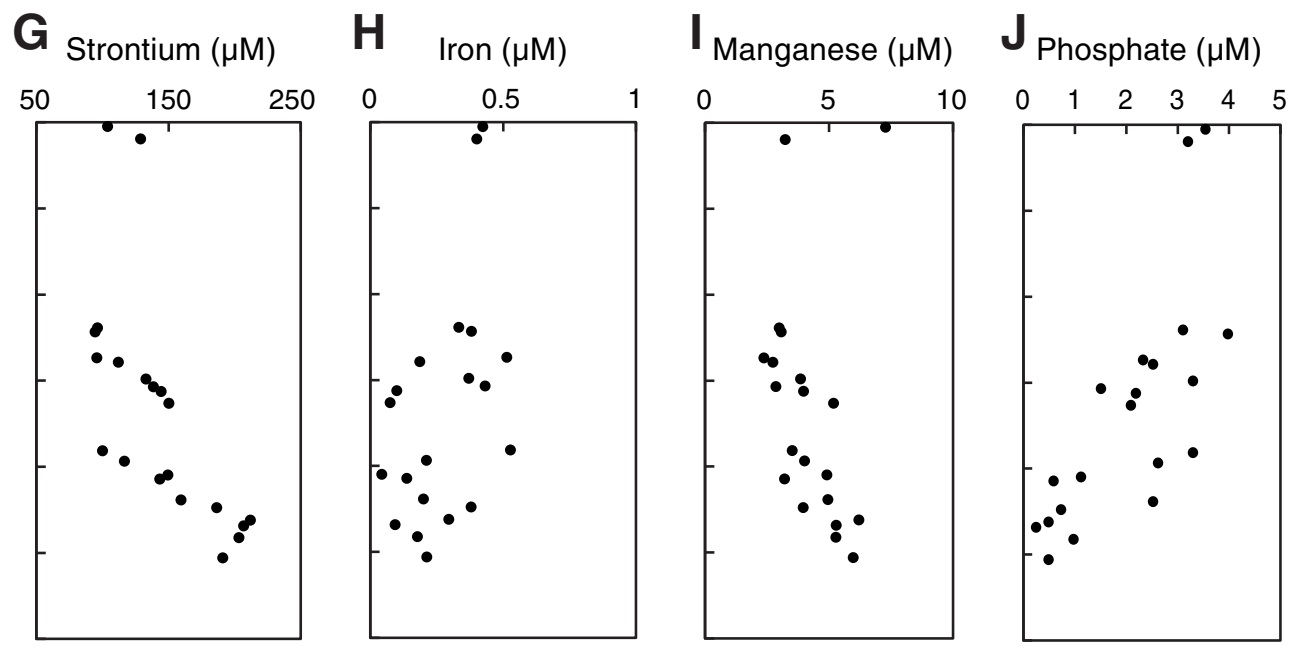
Figure F17. Solid-phase chemical parameters, Hole U1420A. A. Total organic carbon (TOC). B. Total nitrogen (TN). C. TOC/TN ratio (C/N). D. $\mathrm{CaCO}_{3}$. E. Scatter plot of TOC vs. TN. The potential contribution of inorganic $\mathrm{N}$ to the TN signal is estimated where the linear regression line intercepts the $y$-axis (e.g., Schubert and Calvert, 2001). Full details of Lithology column are shown in Figure F6 (see "Lithostratigraphy").
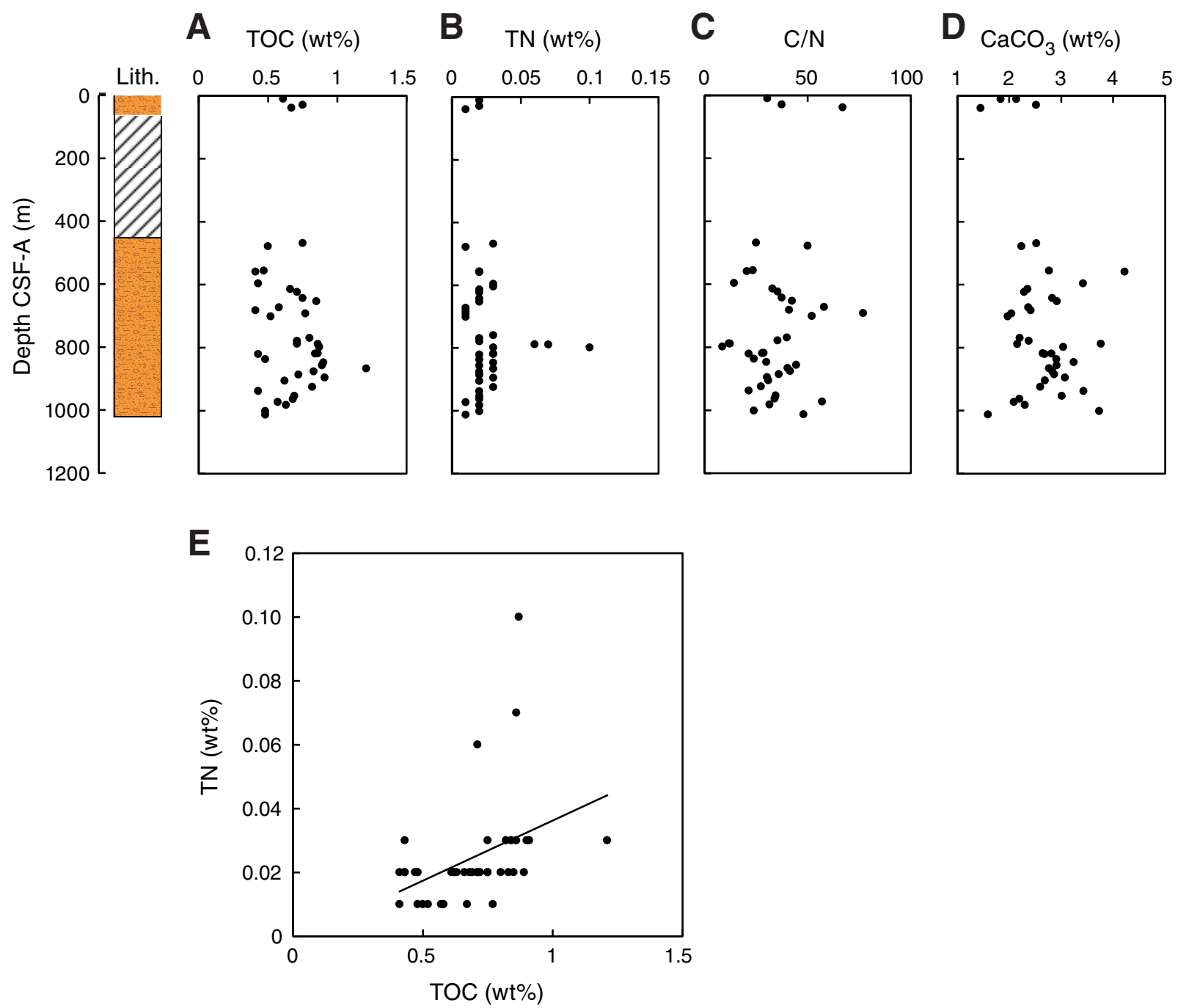
Figure F18. Depth profiles of chlorinity-normalized and original concentrations for selected pore water constituents, Hole U1420A. A. Sulfate. B. Alkalinity. C. Calcium. D. Magnesium. E. Bromide.

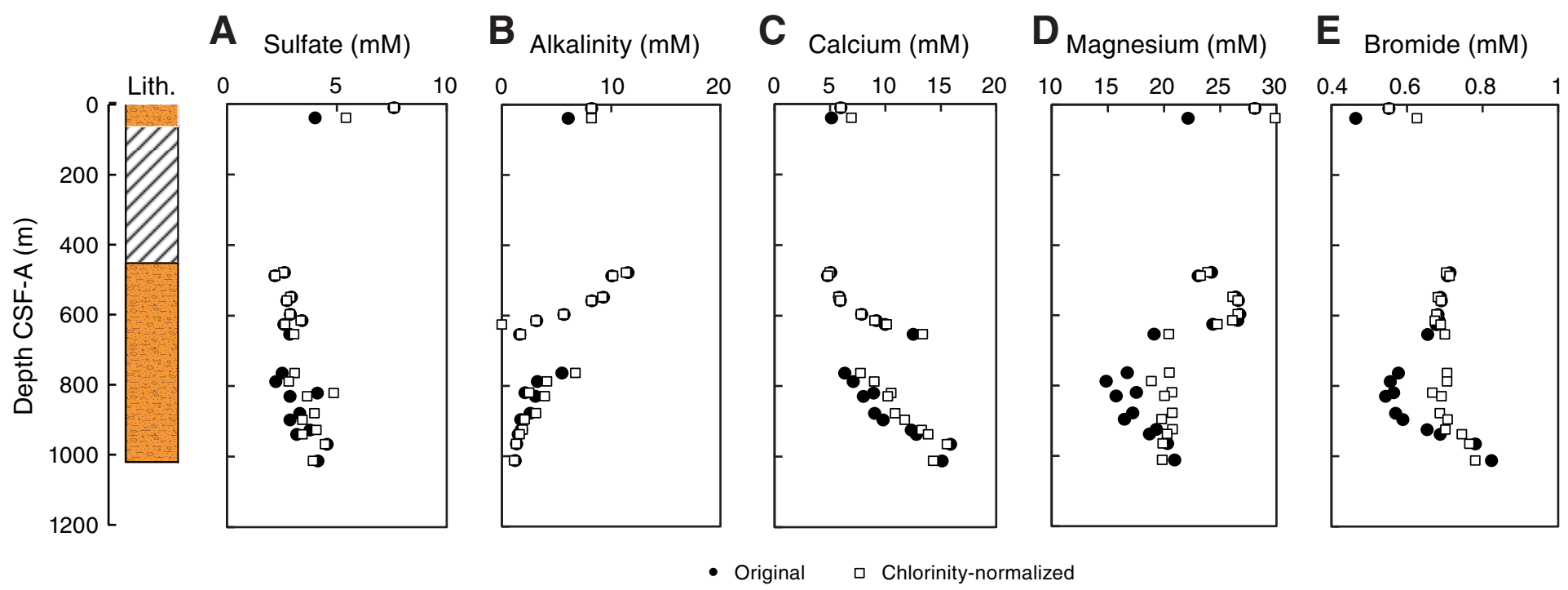


Figure F19. Physical properties measurements, Hole U1420A. WRMSL = Whole-Round Multisensor Logger, MS $=$ magnetic susceptibility. $\mathrm{MAD}=$ moisture and density, GRA = gamma ray attenuation. $\mathrm{NGR}=$ natural gamma radiation. A. 440-710 m CSF-A. (Continued on next page.)

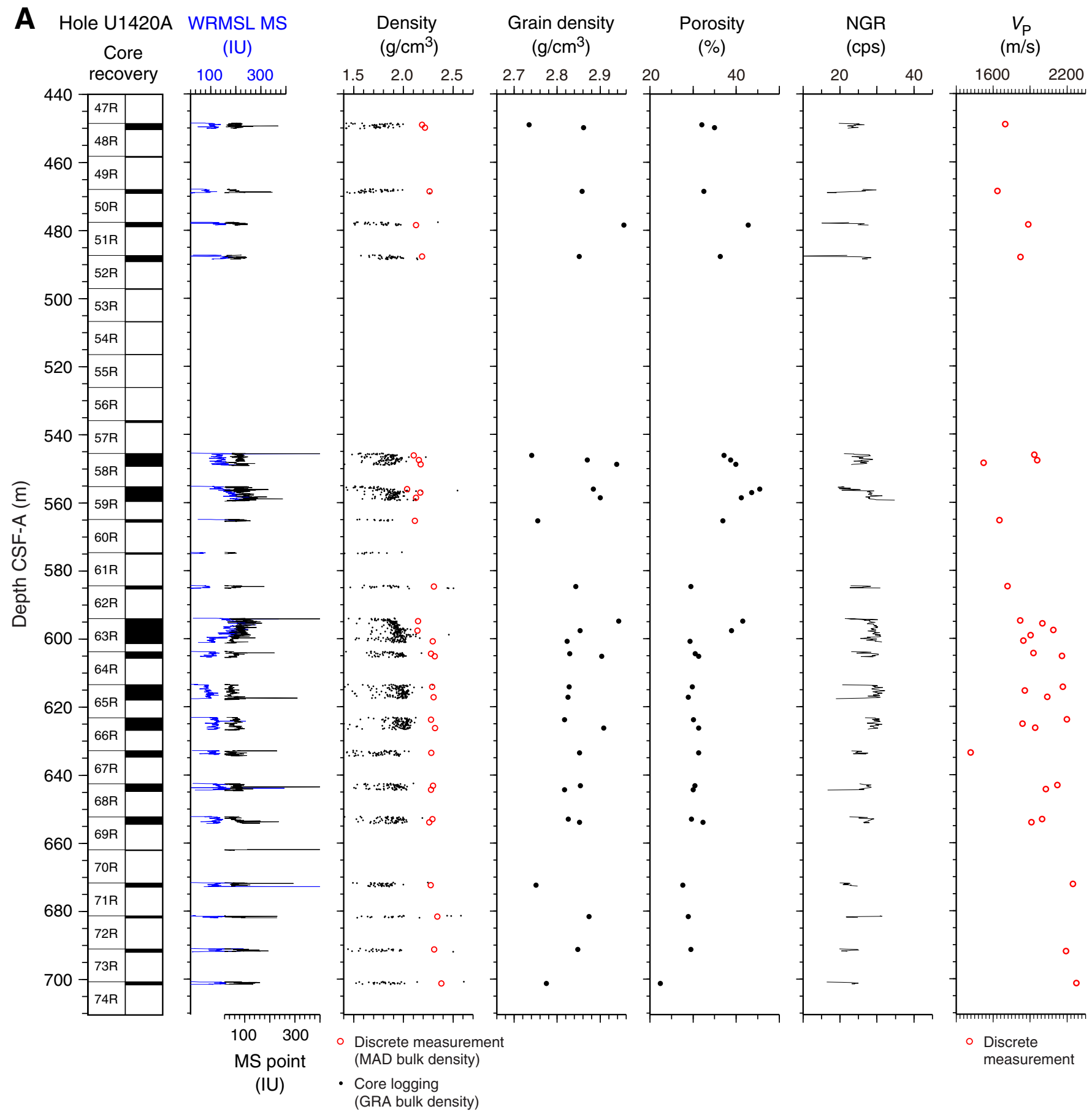


Figure F19 (continued). B. 775-1020 m CSF-A.

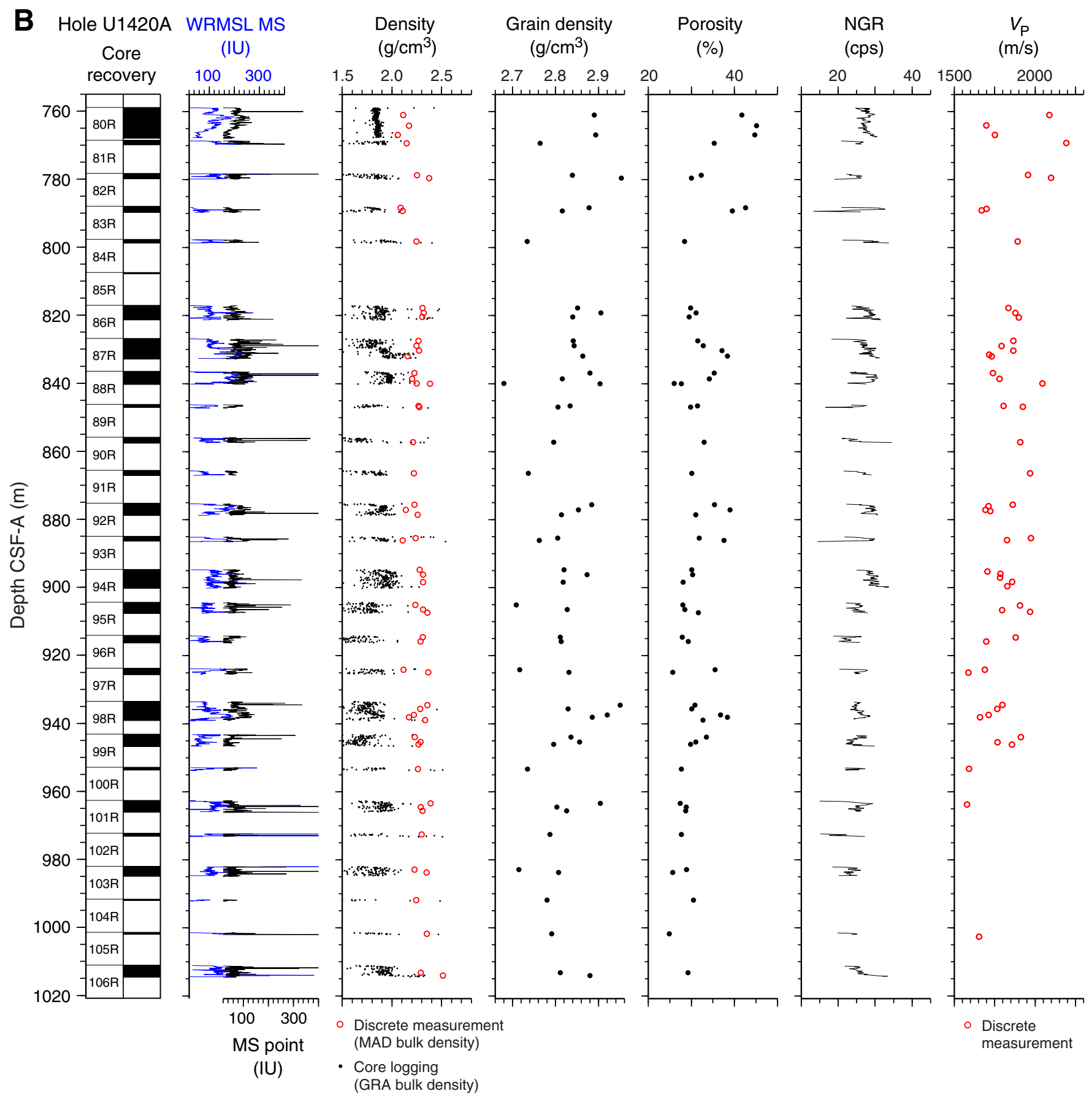


Figure F20. Whole-Round Multisensor Logger (WRMSL) gamma ray attenuation (GRA) bulk density from Site U1420, shown after Gaussian smoothing with a $10 \mathrm{~cm}$ window $( \pm 3 \sigma)$ and interpolation to constant resolution of $2.5 \mathrm{~cm}$, compared to equivalently treated WRMSL magnetic susceptibility (MS) data ( $\kappa$; black). WRMSL MS is also shown corrected for variability in recovered sediment volume by normalizing to WRMSL GRA bulk density, generating specific MS ( $\chi$; blue).

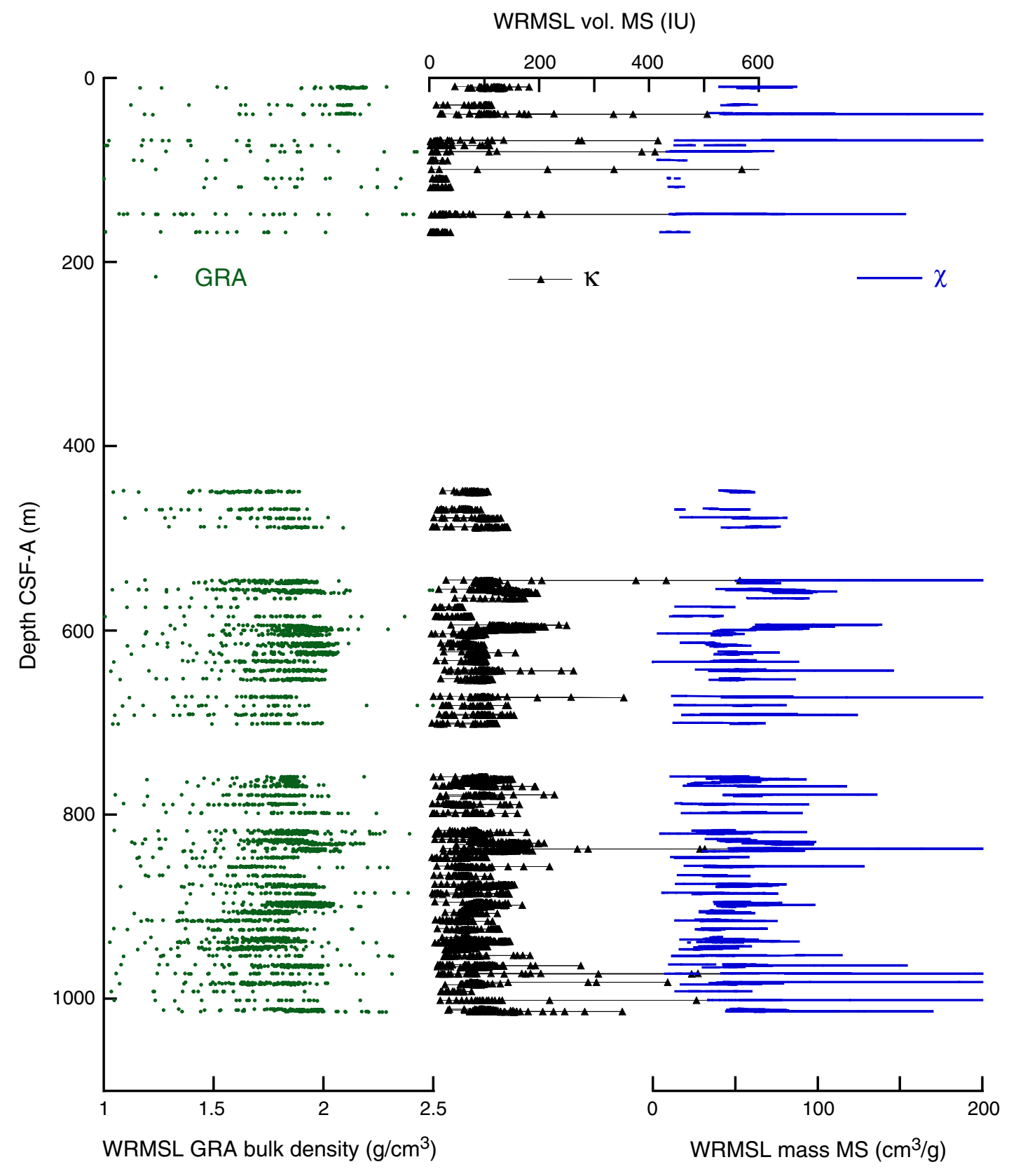


Figure F21. $P$-wave velocity measured by the $P$-wave caliper, Hole U1420A.

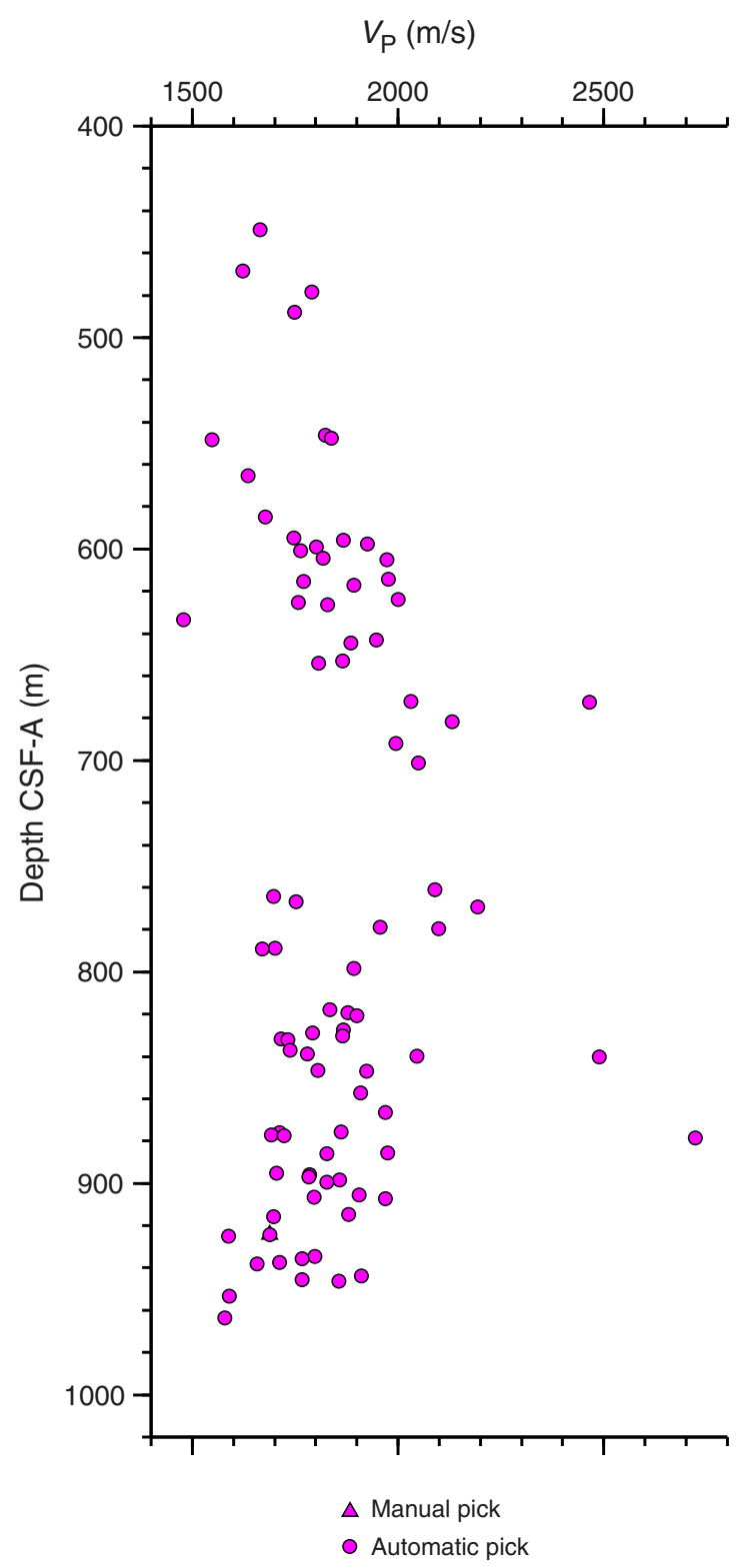


Figure F22. Whole-Round Multisensor Logger (WRMSL) gamma ray attenuation (GRA) bulk density from Site U1420, shown after Gaussian smoothing with a $50 \mathrm{~cm}$ window $( \pm 3 \sigma)$ and interpolation to constant resolution of $10 \mathrm{~cm}$, compared to equivalently treated natural gamma radiation (NGR) data. NGR is also shown corrected for variability in recovered sediment volume by normalizing to WRMSL GRA bulk density.

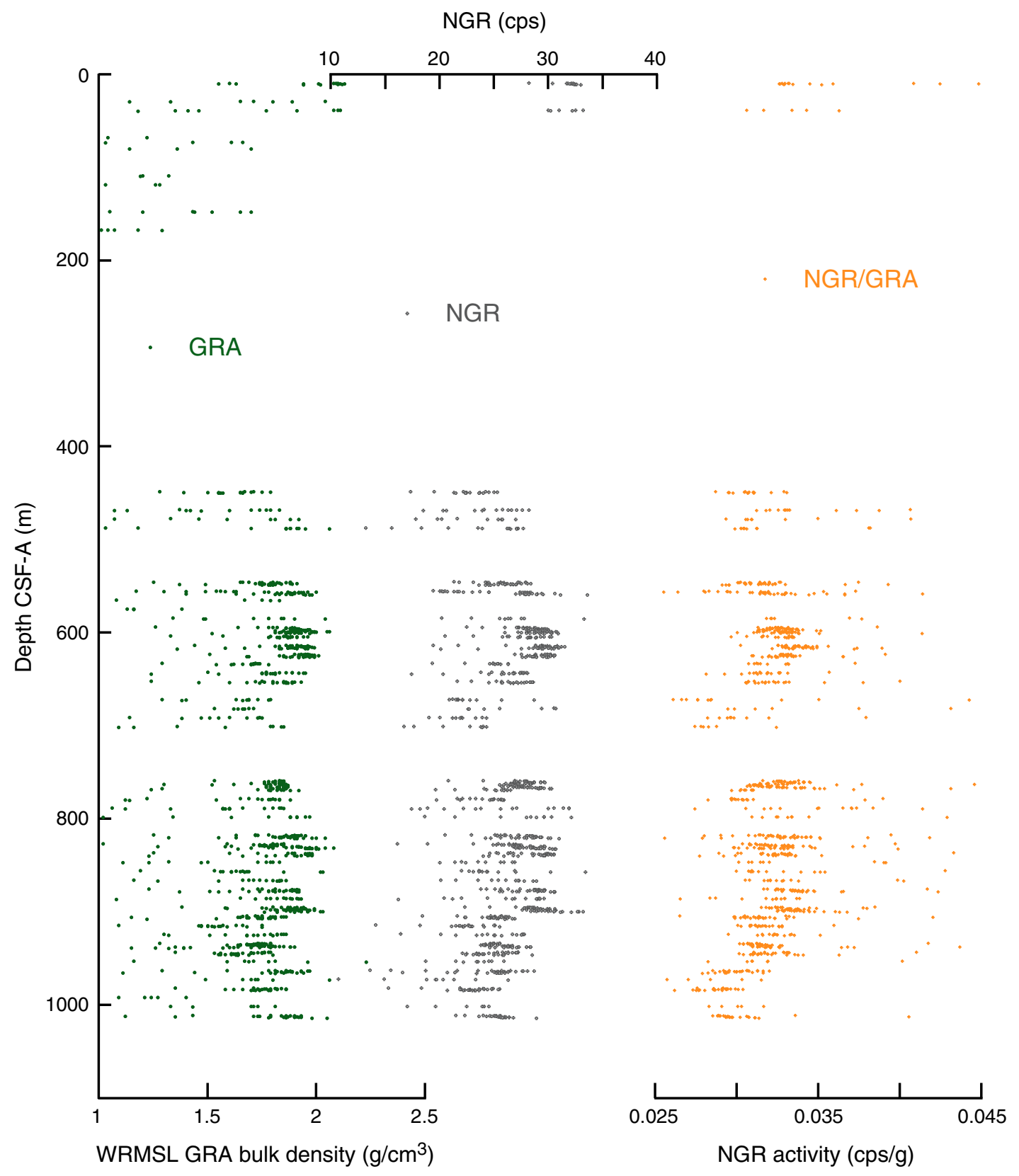


Figure F23. GRA bulk density data measured on the Whole-Round Multisensor Logger (dots) vs. discrete wet bulk density data (circles), Hole U1420A. Sample lithologies: red = clast-rich diamict, brown $=$ clast-poor diamict, green $=$ mud .
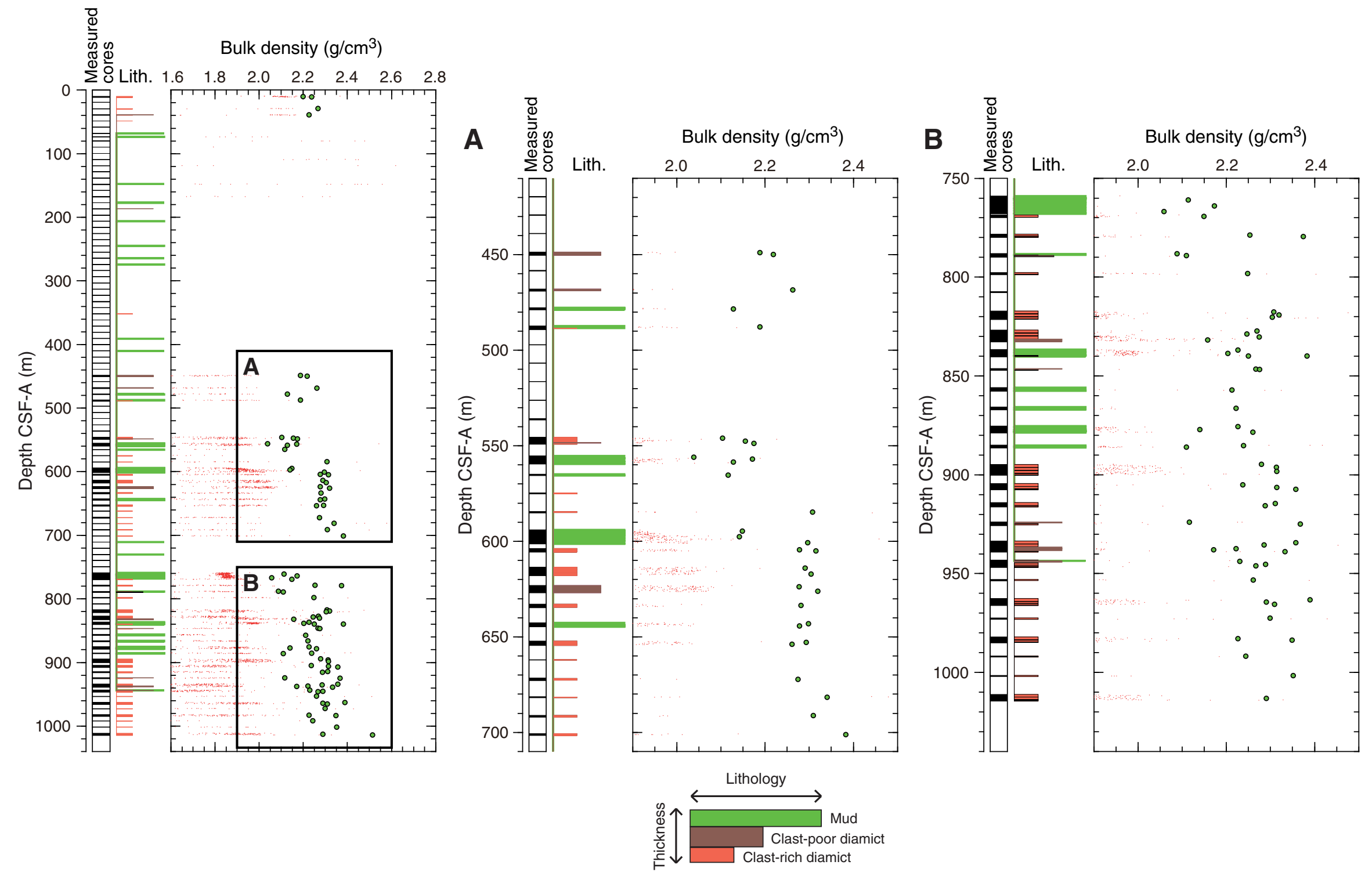
Figure F24. Bulk density, grain density, porosity, and void ratio measured using the moisture and density method, Hole U1420A. Sample lithologies: red = clast-rich diamict, blue = clast-poor diamict, green = mud. For more details on major lithologies, see "Lithostratigraphy."
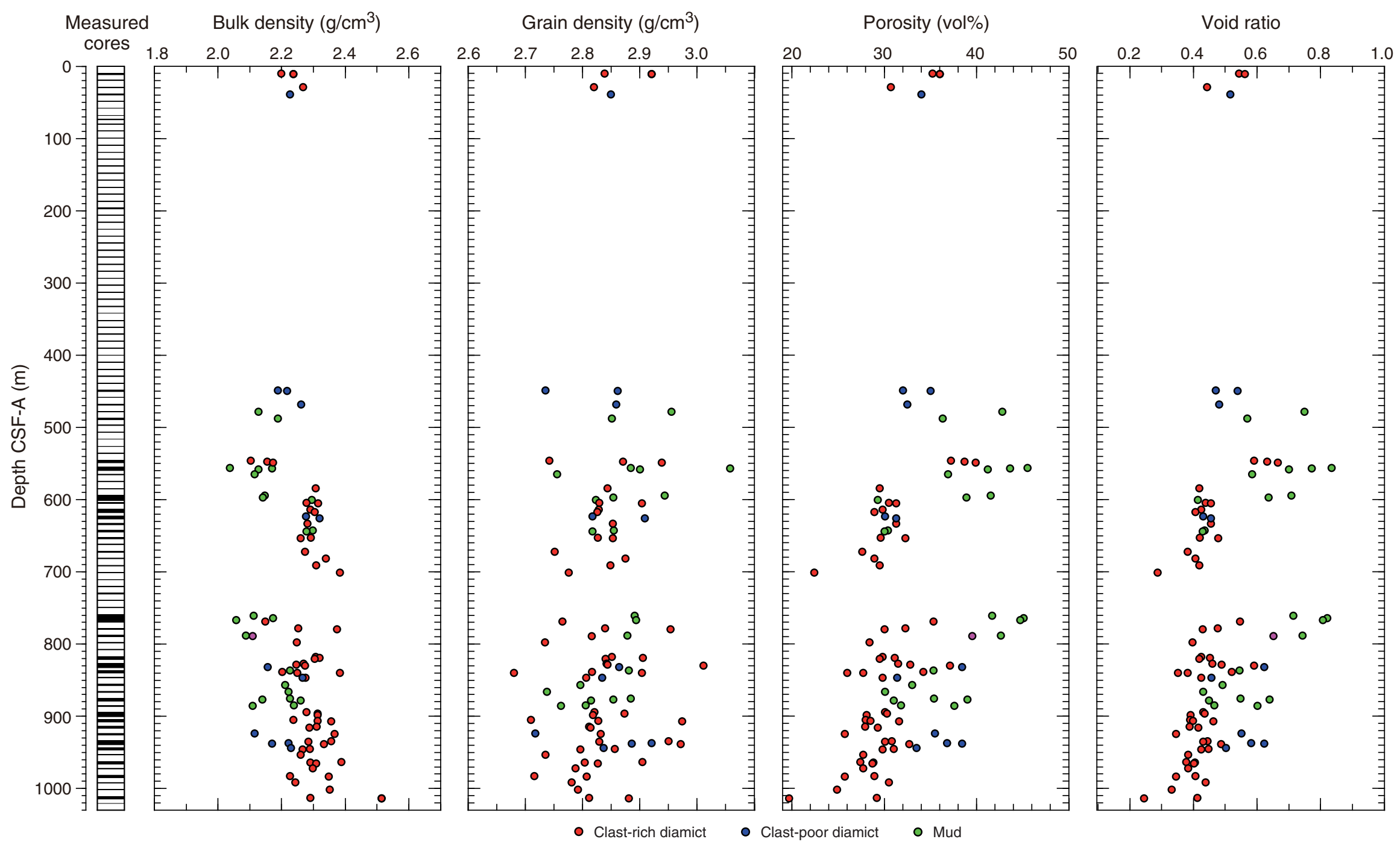
Figure F25. Natural remanent magnetization intensity, declination, and inclination measured before and after 5, 10, 15, and $20 \mathrm{mT}$ peak AF demagnetization, Site U1420.

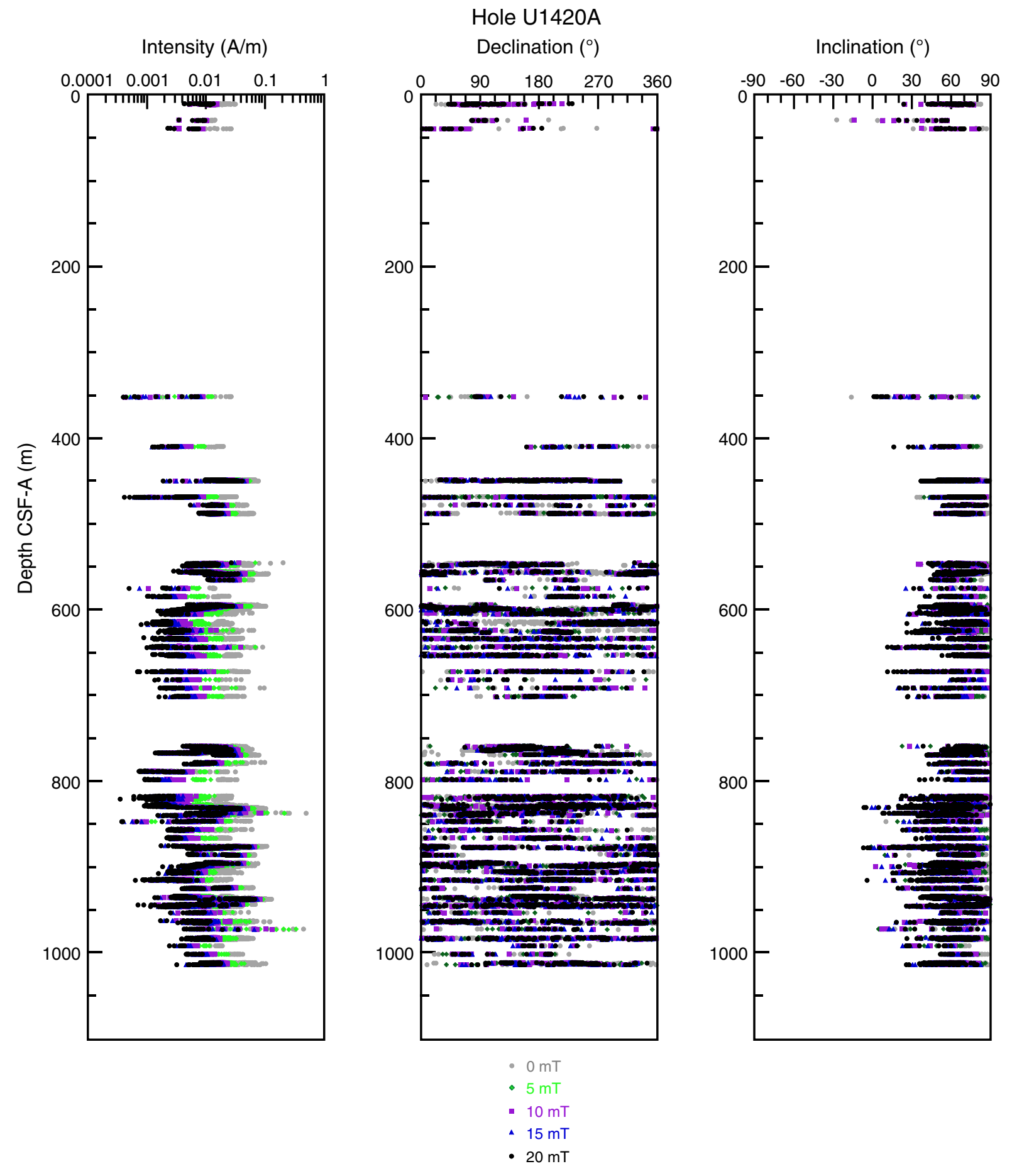


Figure F26. Logging operations summary diagram for Hole U1420A, showing wireline depth reached during logging passes and borehole depths. See Table T6 in the "Methods" chapter (Jaeger et al., 2014) for definitions of depth scales.

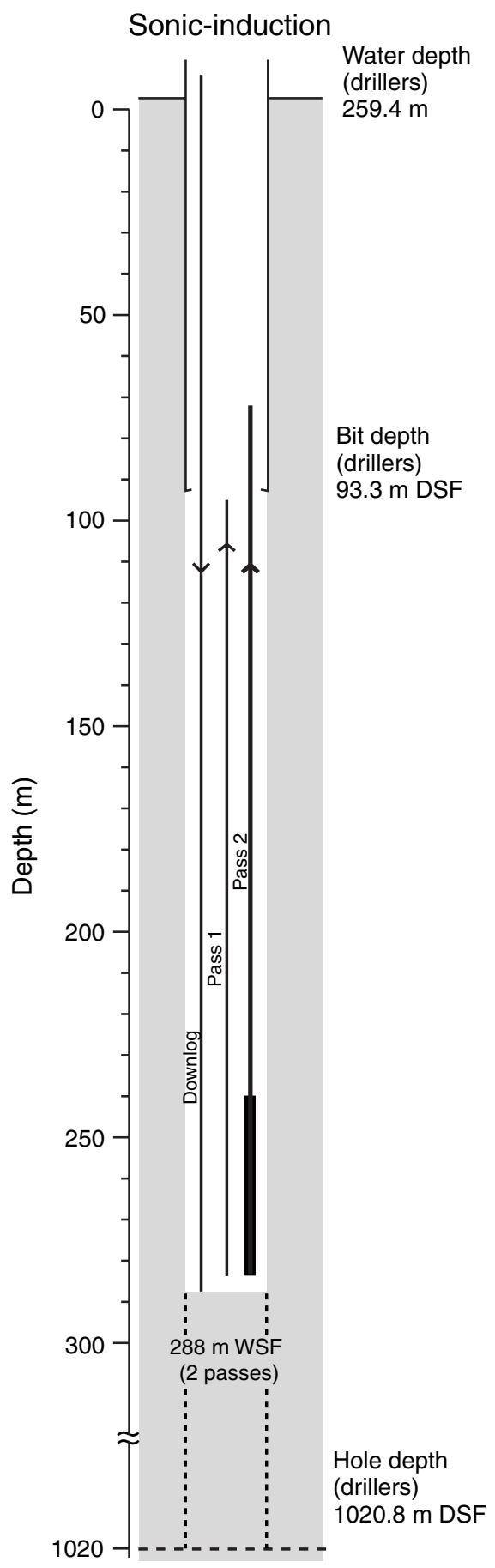


Figure F27. Summary of logs from the Sonic-induction tool string and logging units, Hole U1420A. From the Phasor Dual Induction-Spherically Focused Resistivity Tool: IDPH = deep induction log, IMPH = medium induction $\log$, SFLU = shallow spherically focused resistivity $\log$.

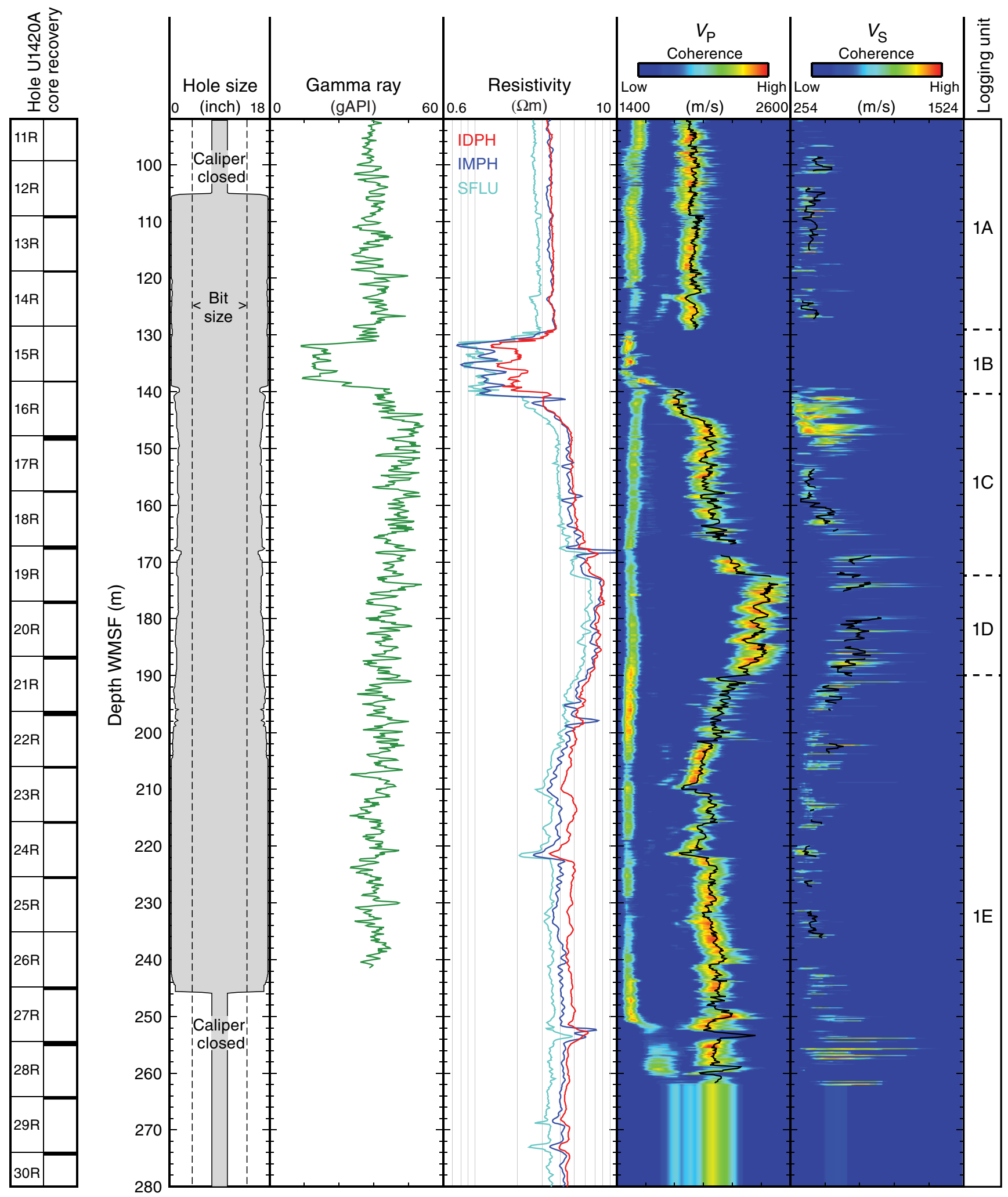


Figure F28. Comparison of the main logs recorded with the Sonic-induction tool string (gamma ray, deep induction resistivity, $P$-wave velocity), Hole U1420A. All data sets show reasonable agreement between the two passes of this tool string, indicating the reliability of the various measurements.

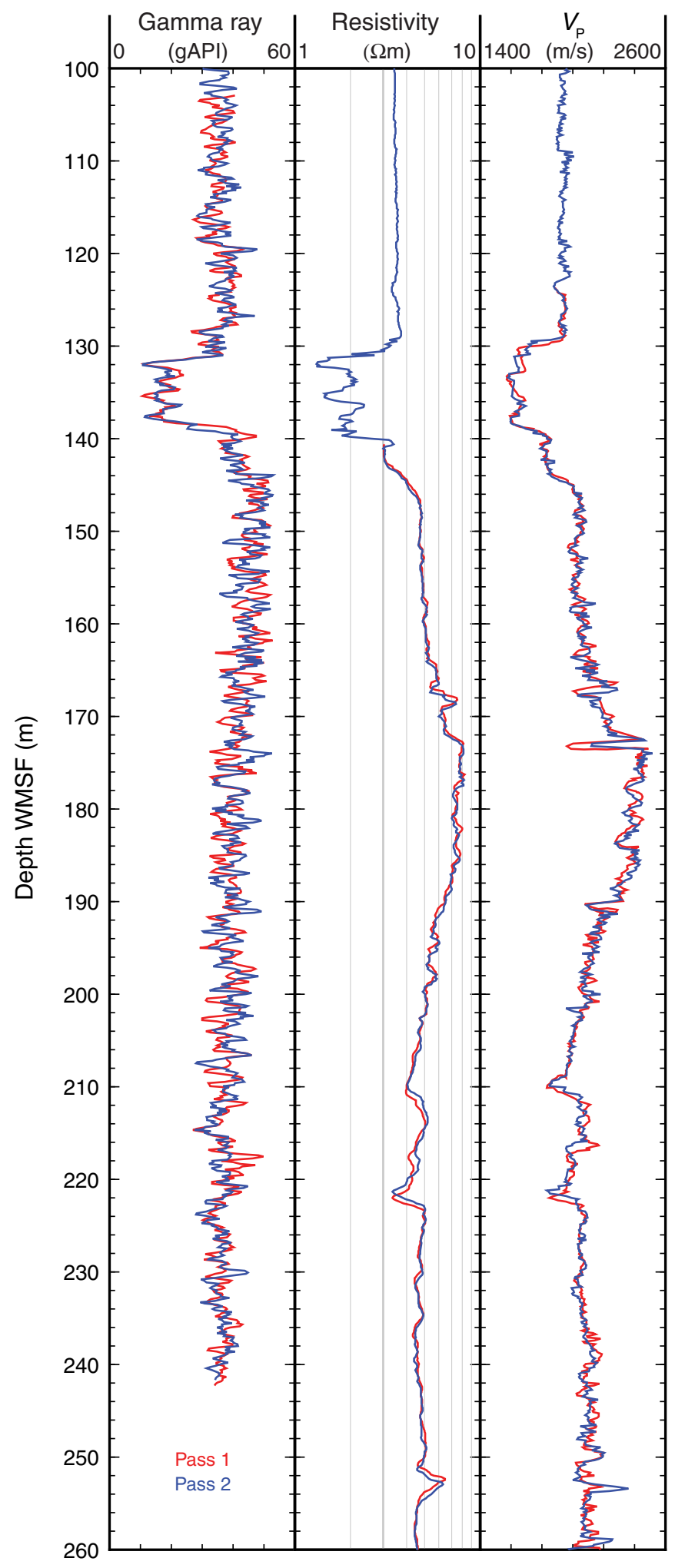


Figure F29. Logging data from the Phasor Dual Induction-Spherically Focused Resistivity Tool, Hole U1420A. Data indicate high resistivity throughout most of the logged interval. IDPH $=$ deep induction log, IMPH $=$ medium induction $\log$, SFLU = shallow spherically focused resistivity log.

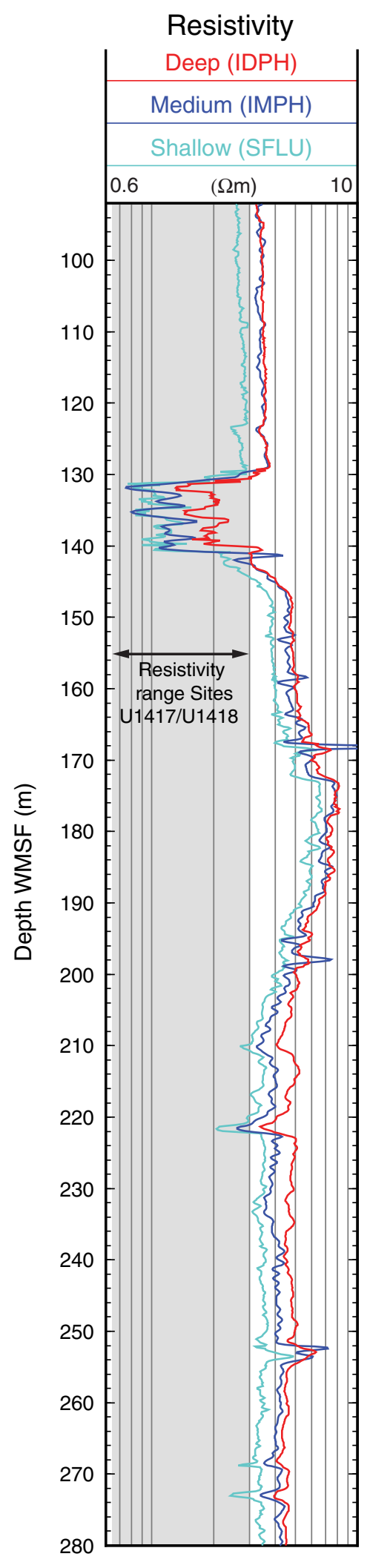


Figure F30. Seismic Profile GOA2505 acquired in 2004 aboard the R/V Maurice Ewing as part of a site survey cruise for Expedition 341 . Vertical resolution at the seafloor $=\sim 5 \mathrm{~m}$. Interpretations based on Worthington et al. $(2008,2010)$ and Berger et al. $(2008)$. Green line $=$ location of Site U1420; see Figure F11 for ranges of possible depths of penetration relative to the seismic data.

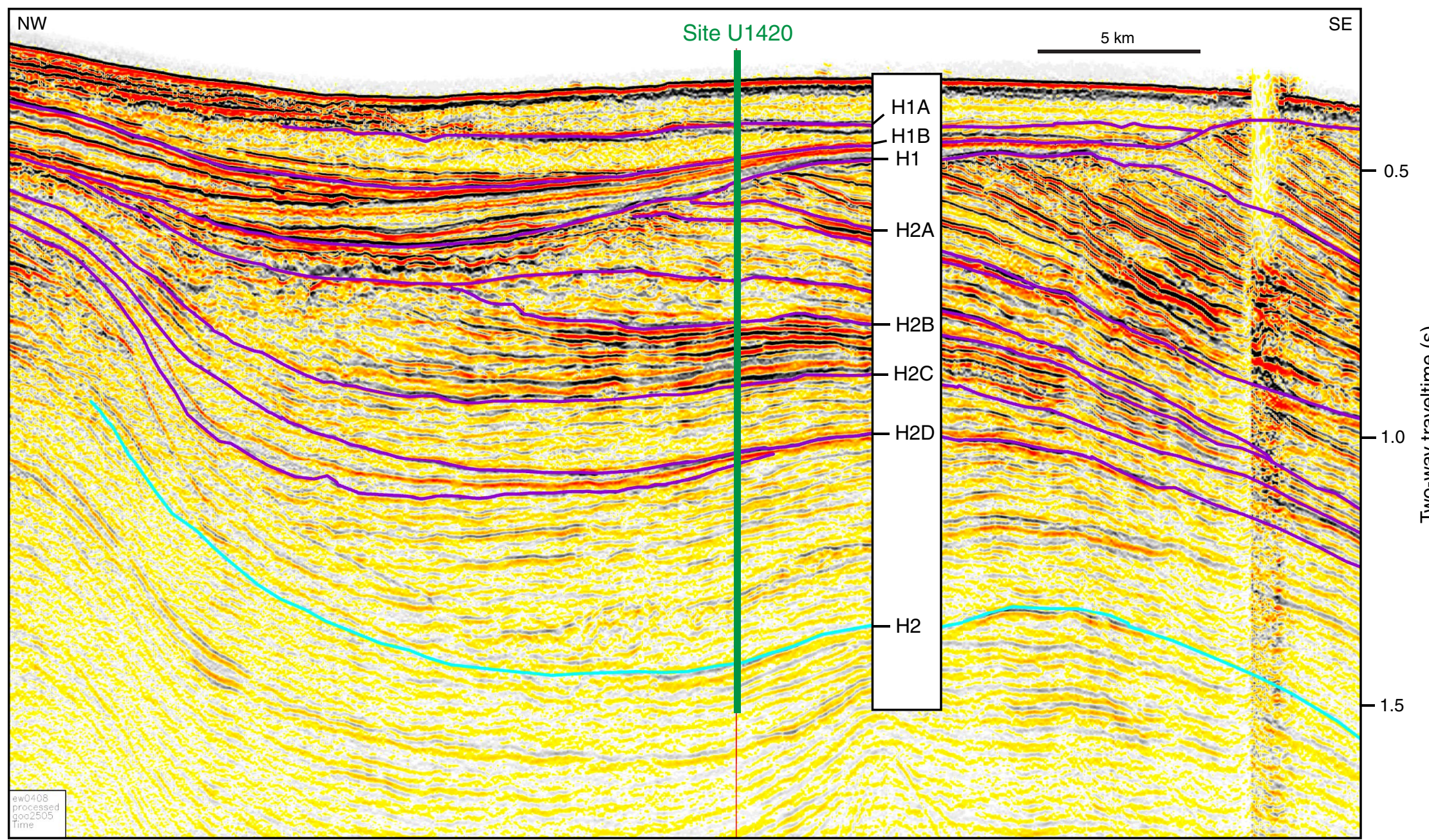


Figure F31. Seismic Profile GOA2502 acquired in 2004 aboard the R/V Maurice Ewing as part of a site survey cruise for Expedition 341. Vertical resolution at the seafloor $=\sim 5 \mathrm{~m}$. Interpretations based on Worthington et al. $(2008,2010)$ and Berger et al. (2008). Vertical red lines = positions of proposed (solid) and previously drilled (dashed) industry sites. Green line = position of Site U1420. See Figure F11 for ranges of possible depths of penetration of Site U1420 relative to the seismic data.

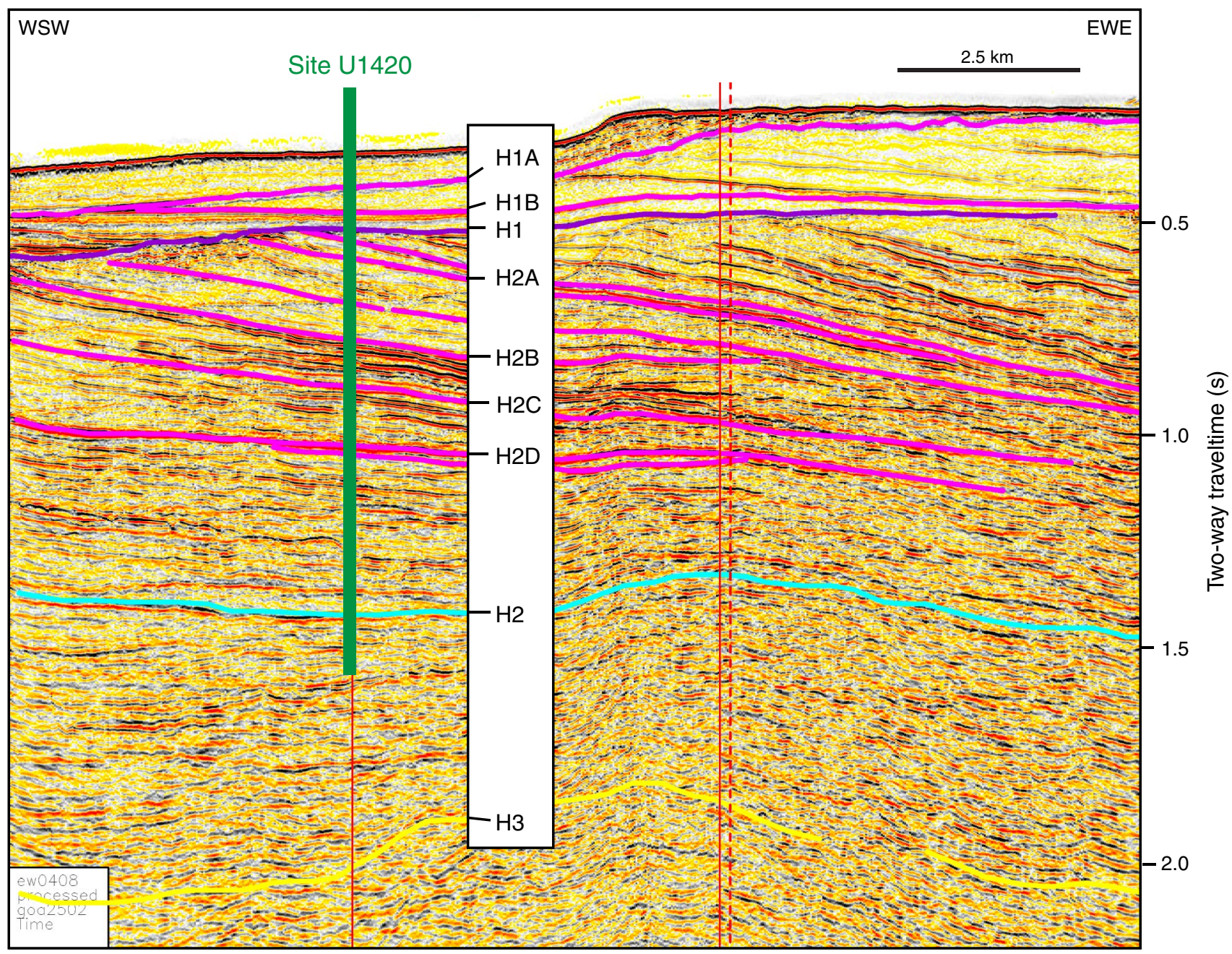


Table T1. Coring summary, Site U1420. (Continued on next page.)

\begin{tabular}{|c|c|c|c|c|c|c|c|c|c|c|}
\hline \\
\hline & \multicolumn{10}{|c|}{$\begin{array}{l}\text { Hole U1420A } \\
\text { Latitude: } 59^{\circ} 41.3399^{\prime} \mathrm{N}\end{array}$} \\
\hline \multicolumn{11}{|c|}{$\begin{array}{l}\text { Latitude: } 59^{\circ} 41.3399^{\prime} \mathrm{N} \\
\text { Longitude: } 143^{\circ} 12.0599^{\prime} \mathrm{W}\end{array}$} \\
\hline \multicolumn{11}{|c|}{$\begin{array}{l}\text { Longitude: } 143^{\circ} 12.0599^{\prime} \mathrm{W} \\
\text { Time on hole (h): } 189.25\end{array}$} \\
\hline \multicolumn{11}{|c|}{$\begin{array}{l}\text { Time on hole }(\mathrm{h}): 189.25 \\
\text { Seafloor (drill pipe measurement below rig floor, } \mathrm{m} \text { DRF): } 259.4\end{array}$} \\
\hline \multicolumn{11}{|c|}{ Distance between rig floor and sea level $(\mathrm{m}): 11.2$} \\
\hline \multicolumn{11}{|c|}{ Water depth (drill pipe measurement from sea level, mbsl): 248.2} \\
\hline \multirow{2}{*}{\multicolumn{11}{|c|}{ Total penetration (drilling depth below seafloor, m DSF): 1020.8}} \\
\hline \multirow{2}{*}{\multicolumn{11}{|c|}{ Total length of cored section $(\mathrm{m}): 1020.8$}} \\
\hline \multicolumn{2}{|c|}{ Total core recovered $(\mathrm{m}): 139.91$} & & & & & & & & & \\
\hline Core $\mathrm{r}$ & overy (\%) & $: 13.7$ & & & & & & & & \\
\hline Total $\mathrm{r}$ & nber of cc & ores: 106 & & & & & & & & \\
\hline & & & Depth & $S F(m)$ & & Depth & ESF $(\mathrm{m})$ & & & \\
\hline Core & $\begin{array}{l}\text { Date } \\
(2013)\end{array}$ & $\begin{array}{l}\text { UTC time } \\
\text { (h) }\end{array}$ & $\begin{array}{c}\text { Top } \\
\text { of cored } \\
\text { interval }\end{array}$ & $\begin{array}{l}\text { Bottom } \\
\text { of cored } \\
\text { interval }\end{array}$ & $\begin{array}{l}\text { Interval } \\
\text { advanced } \\
\text { (m) }\end{array}$ & $\begin{array}{c}\text { Top } \\
\text { of cored } \\
\text { interval }\end{array}$ & $\begin{array}{l}\text { Bottom } \\
\text { of cored } \\
\text { interval }\end{array}$ & $\begin{array}{l}\text { of core } \\
\text { recovered } \\
(\mathrm{m})\end{array}$ & $\begin{array}{c}\text { Recovery } \\
\text { (\%) }\end{array}$ & $\begin{array}{l}\text { Sections } \\
(N)\end{array}$ \\
\hline 341-U14 & & & & & & & & & & \\
\hline $1 \mathrm{R}$ & $14 \mathrm{Jul}$ & 1910 & 0 & 9.7 & 9.7 & 0 & 0 & 0 & 0 & 0 \\
\hline $2 \mathrm{R}$ & $14 \mathrm{Jul}$ & 2030 & 9.7 & 19.4 & 9.7 & 9.7 & 11.44 & 1.74 & 18 & 3 \\
\hline $3 \mathrm{R}$ & $14 \mathrm{Jul}$ & 2130 & 19.4 & 29.1 & 9.7 & 19.4 & 19.42 & 0.02 & 0 & 1 \\
\hline $4 \mathrm{R}$ & 14 Jul & 2210 & 29.1 & 38.8 & 9.7 & 29.1 & 29.8 & 0.70 & 7 & 2 \\
\hline $5 \mathrm{R}$ & $14 \mathrm{Jul}$ & 2245 & 38.8 & 48.5 & 9.7 & 38.8 & 39.75 & 0.95 & 10 & 2 \\
\hline $6 \mathrm{R}$ & $14 \mathrm{Jul}$ & 2325 & 48.5 & 58.2 & 9.7 & 48.5 & 48.67 & 0.17 & 2 & 1 \\
\hline $7 \mathrm{R}$ & $15 \mathrm{Jul}$ & 0000 & 58.2 & 67.9 & 9.7 & 58.2 & 58.27 & 0.05 & 1 & 1 \\
\hline $8 \mathrm{R}$ & $15 \mathrm{Jul}$ & 0140 & 67.9 & 73.4 & 5.5 & 67.9 & 68.30 & 0.43 & 8 & 1 \\
\hline $9 \mathrm{R}$ & $15 \mathrm{Jul}$ & 0315 & 73.4 & 79.9 & 6.5 & 73.4 & 73.81 & 0.41 & 6 & 1 \\
\hline $10 \mathrm{R}$ & $15 \mathrm{Jul}$ & 0455 & 79.9 & 89.6 & 9.7 & 79.9 & 80.25 & 0.32 & 3 & 1 \\
\hline $11 \mathrm{R}$ & 15 Jul & 0610 & 89.6 & 99.3 & 9.7 & 89.6 & 89.78 & 0.15 & 2 & 1 \\
\hline $12 \mathrm{R}$ & $15 \mathrm{Jul}$ & 0710 & 99.3 & 109.0 & 9.7 & 99.3 & 99.38 & 0.08 & 1 & 1 \\
\hline $13 R$ & 15 Jul & 0810 & 109.0 & 118.7 & 9.7 & 109.0 & 109.59 & 0.41 & 4 & 1 \\
\hline $14 \mathrm{R}$ & $15 \mathrm{Jul}$ & 0900 & 118.7 & 128.4 & 9.7 & 118.7 & 119.03 & 0.26 & 3 & 1 \\
\hline $15 R$ & $15 \mathrm{Jul}$ & 0950 & 128.4 & 138.1 & 9.7 & 128.4 & 128.46 & 0.06 & 1 & 1 \\
\hline $16 \mathrm{R}$ & $15 \mathrm{Jul}$ & 1040 & 138.1 & 147.8 & 9.7 & 138.1 & 138.31 & 0.16 & 2 & 1 \\
\hline $17 R$ & $15 \mathrm{Jul}$ & 1140 & 147.8 & 157.5 & 9.7 & 147.8 & 148.66 & 0.73 & 8 & 1 \\
\hline $18 \mathrm{R}$ & $15 \mathrm{Jul}$ & 1255 & 157.5 & 167.2 & 9.7 & 157.5 & 157.73 & 0.21 & 2 & 1 \\
\hline $19 \mathrm{R}$ & $15 \mathrm{Jul}$ & 1415 & 167.2 & 176.9 & 9.7 & 167.2 & 167.99 & 0.58 & 6 & 1 \\
\hline $20 \mathrm{R}$ & $15 \mathrm{Jul}$ & 1540 & 176.9 & 186.6 & 9.7 & 176.9 & 177.33 & 0.40 & 4 & 1 \\
\hline $21 \mathrm{R}$ & $15 \mathrm{Jul}$ & 1655 & 186.6 & 196.3 & 9.7 & 186.6 & 187.26 & 0.52 & 5 & 1 \\
\hline $22 \mathrm{R}$ & $15 \mathrm{Jul}$ & 1810 & 196.3 & 206.0 & 9.7 & 196.3 & 197.25 & 0.78 & 8 & 1 \\
\hline $23 \mathrm{R}$ & $15 \mathrm{Jul}$ & 1910 & 206.0 & 215.7 & 9.7 & 206.0 & 206.49 & 0.30 & 3 & 1 \\
\hline $24 R$ & $15 \mathrm{Jul}$ & 2010 & 215.7 & 225.4 & 9.7 & 215.7 & 216.08 & 0.29 & 3 & 1 \\
\hline $25 R$ & $15 \mathrm{Jul}$ & 2100 & 225.4 & 235.1 & 9.7 & 225.4 & 225.92 & 0.30 & 3 & 1 \\
\hline $26 \mathrm{R}$ & $15 \mathrm{Jul}$ & 2155 & 235.1 & 244.8 & 9.7 & 235.1 & 235.10 & 0 & 0 & 0 \\
\hline $27 \mathrm{R}$ & $15 \mathrm{Jul}$ & 2255 & 244.8 & 254.5 & 9.7 & 244.8 & 245.40 & 0.46 & 5 & 1 \\
\hline $28 \mathrm{R}$ & $16 \mathrm{Jul}$ & 0020 & 254.5 & 264.2 & 9.7 & 254.5 & 255.44 & 0.68 & 7 & 1 \\
\hline $29 R$ & $16 \mathrm{Jul}$ & 0155 & 264.2 & 273.9 & 9.7 & 264.2 & 264.68 & 0.40 & 4 & 1 \\
\hline $30 R$ & $16 \mathrm{Jul}$ & 0310 & 273.9 & 283.6 & 9.7 & 273.9 & 274.43 & 0.50 & 5 & 1 \\
\hline $31 \mathrm{R}$ & $16 \mathrm{Jul}$ & 0425 & 283.6 & 293.3 & 9.7 & 283.6 & 283.97 & 0.30 & 3 & 1 \\
\hline $32 \mathrm{R}$ & 16 Jul & 0520 & 293.3 & 303.0 & 9.7 & 293.3 & 293.37 & 0.06 & 1 & 1 \\
\hline $33 R$ & $16 \mathrm{Jul}$ & 0625 & 303.0 & 312.7 & 9.7 & 303.0 & 303.49 & 0.43 & 4 & 1 \\
\hline $34 \mathrm{R}$ & $16 \mathrm{Jul}$ & 0715 & 312.7 & 322.4 & 9.7 & 312.7 & 313.14 & 0.45 & 5 & 1 \\
\hline $35 \mathrm{R}$ & 16 Jul & 0805 & 322.4 & 332.1 & 9.7 & 322.4 & 322.90 & 0.41 & 4 & 1 \\
\hline $36 \mathrm{R}$ & $16 \mathrm{Jul}$ & 0910 & 332.1 & 341.8 & 9.7 & 332.1 & 333.05 & 0.77 & 8 & 1 \\
\hline $37 R$ & 16 Jul & 1025 & 341.8 & 351.5 & 9.7 & 341.8 & 342.06 & 0.19 & 2 & 1 \\
\hline $38 \mathrm{R}$ & $16 \mathrm{Jul}$ & 1125 & 351.5 & 361.2 & 9.7 & 351.5 & 352.25 & 0.60 & 6 & 1 \\
\hline $39 \mathrm{R}$ & $16 \mathrm{Jul}$ & 1225 & 361.2 & 370.9 & 9.7 & 361.2 & 361.67 & 0.30 & 3 & 1 \\
\hline $40 R$ & $16 \mathrm{Jul}$ & 1325 & 370.9 & 380.6 & 9.7 & 370.9 & 371.20 & 0.21 & 2 & 1 \\
\hline $41 \mathrm{R}$ & $16 \mathrm{Jul}$ & 1420 & 380.6 & 390.3 & 9.7 & 380.6 & 380.89 & 0.23 & 2 & 1 \\
\hline $42 \mathrm{R}$ & $16 \mathrm{Jul}$ & 1530 & 390.3 & 400.0 & 9.7 & 390.3 & 390.83 & 0.49 & 5 & 1 \\
\hline $43 R$ & $16 \mathrm{Jul}$ & 1625 & 400.0 & 409.7 & 9.7 & 400.0 & 400.05 & 0.03 & 0 & 1 \\
\hline $44 \mathrm{R}$ & 16 Jul & 1725 & 409.7 & 419.4 & 9.7 & 409.7 & 410.32 & 0.56 & 6 & 1 \\
\hline $45 \mathrm{R}$ & $16 \mathrm{Jul}$ & 1825 & 419.4 & 429.1 & 9.7 & 419.4 & 419.89 & 0.37 & 4 & 1 \\
\hline $46 \mathrm{R}$ & $16 \mathrm{Jul}$ & 1930 & 429.1 & 438.8 & 9.7 & 429.1 & 429.33 & 0.23 & 2 & 1 \\
\hline $47 R$ & $16 \mathrm{Jul}$ & 2035 & 438.8 & 448.5 & 9.7 & 438.8 & 438.96 & 0.18 & 2 & 1 \\
\hline $48 R$ & $16 \mathrm{Jul}$ & 2140 & 448.5 & 458.2 & 9.7 & 448.5 & 450.40 & 1.90 & 20 & 3 \\
\hline $49 R$ & 16 Jul & 2250 & 458.2 & 467.9 & 9.7 & 458.2 & 458.53 & 0.28 & 3 & 1 \\
\hline $50 \mathrm{R}$ & $16 \mathrm{Jul}$ & 2350 & 467.9 & 477.6 & 9.7 & 467.9 & 469.13 & 1.23 & 13 & 1 \\
\hline $51 \mathrm{R}$ & 17 Jul & 0055 & 477.6 & 487.3 & 9.7 & 477.6 & 478.88 & 1.28 & 13 & 2 \\
\hline $52 \mathrm{R}$ & $17 \mathrm{Jul}$ & 0215 & 487.3 & 497.0 & 9.7 & 487.3 & 489.15 & 1.81 & 19 & 2 \\
\hline
\end{tabular}


Table T1 (continued).

\begin{tabular}{|c|c|c|c|c|c|c|c|c|c|c|}
\hline \multirow[b]{2}{*}{ Core } & \multirow[b]{2}{*}{$\begin{array}{l}\text { Date } \\
(2013)\end{array}$} & \multirow[b]{2}{*}{$\begin{array}{l}\text { UTC time } \\
\text { (h) }\end{array}$} & \multicolumn{2}{|c|}{ Depth DSF (m) } & \multirow[b]{2}{*}{$\begin{array}{l}\text { Interval } \\
\text { advanced } \\
\text { (m) }\end{array}$} & \multicolumn{2}{|c|}{ Depth CSF (m) } & \multirow{2}{*}{$\begin{array}{l}\text { Length } \\
\text { of core } \\
\text { recovered } \\
(\mathrm{m})\end{array}$} & \multirow[b]{2}{*}{$\begin{array}{c}\text { Recovery } \\
\text { (\%) }\end{array}$} & \multirow[b]{2}{*}{$\begin{array}{l}\text { Section } \\
(N)\end{array}$} \\
\hline & & & $\begin{array}{c}\text { Top } \\
\text { of cored } \\
\text { interval }\end{array}$ & $\begin{array}{l}\text { Bottom } \\
\text { of cored } \\
\text { interval }\end{array}$ & & $\begin{array}{c}\text { Top } \\
\text { of cored } \\
\text { interval }\end{array}$ & $\begin{array}{l}\text { Bottom } \\
\text { of cored } \\
\text { interval }\end{array}$ & & & \\
\hline $53 \mathrm{R}$ & $17 \mathrm{Jul}$ & 0315 & 497.0 & 506.7 & 9.7 & 497.0 & 497.26 & 0.26 & 3 & 1 \\
\hline $54 \mathrm{R}$ & $17 \mathrm{Jul}$ & 0440 & 506.7 & 516.4 & 9.7 & 506.7 & 506.88 & 0.22 & 2 & 1 \\
\hline $55 \mathrm{R}$ & $17 \mathrm{Jul}$ & 0600 & 516.4 & 526.1 & 9.7 & 516.4 & 516.40 & 0 & 0 & 0 \\
\hline $56 \mathrm{R}$ & 17 Jul & 0715 & 526.1 & 535.8 & 9.7 & 526.1 & 526.10 & 0 & 0 & 0 \\
\hline $57 \mathrm{R}$ & 17 Jul & 0920 & 535.8 & 545.5 & 9.7 & 535.8 & 536.41 & 0.50 & 5 & 1 \\
\hline $58 \mathrm{R}$ & $17 \mathrm{Jul}$ & 1040 & 545.5 & 555.2 & 9.7 & 545.5 & 549.29 & 3.79 & 39 & 4 \\
\hline $59 \mathrm{R}$ & $17 \mathrm{Jul}$ & 1150 & 555.2 & 564.9 & 9.7 & 555.2 & 559.64 & 4.44 & 46 & 4 \\
\hline $60 \mathrm{R}$ & 17 Jul & 1310 & 564.9 & 574.6 & 9.7 & 564.9 & 565.66 & 0.76 & 8 & 2 \\
\hline $61 \mathrm{R}$ & $17 \mathrm{Jul}$ & 1435 & 574.6 & 584.3 & 9.7 & 574.6 & 575.09 & 0.53 & 5 & 1 \\
\hline $62 \mathrm{R}$ & $17 \mathrm{Jul}$ & 1600 & 584.3 & 594.0 & 9.7 & 584.3 & 585.24 & 0.94 & 10 & 1 \\
\hline $63 \mathrm{R}$ & $17 \mathrm{Jul}$ & 1725 & 594.0 & 603.7 & 9.7 & 594.0 & 601.36 & 7.36 & 76 & 6 \\
\hline $64 \mathrm{R}$ & $17 \mathrm{Jul}$ & 1900 & 603.7 & 613.4 & 9.7 & 603.7 & 605.65 & 1.95 & 20 & 3 \\
\hline $65 \mathrm{R}$ & $17 \mathrm{Jul}$ & 2025 & 613.4 & 623.1 & 9.7 & 613.4 & 617.97 & 4.57 & 47 & 4 \\
\hline $66 \mathrm{R}$ & $17 \mathrm{Jul}$ & 2135 & 623.1 & 632.8 & 9.7 & 623.1 & 626.87 & 3.77 & 39 & 4 \\
\hline $67 \mathrm{R}$ & $17 \mathrm{Jul}$ & 2305 & 632.8 & 642.5 & 9.7 & 632.8 & 634.72 & 1.92 & 20 & 3 \\
\hline $68 \mathrm{R}$ & $18 \mathrm{Jul}$ & 0045 & 642.5 & 652.2 & 9.7 & 642.5 & 644.78 & 2.28 & 24 & 3 \\
\hline $69 \mathrm{R}$ & $18 \mathrm{Jul}$ & 0220 & 652.2 & 661.9 & 9.7 & 652.2 & 654.45 & 2.25 & 23 & 3 \\
\hline $70 R$ & $18 \mathrm{Jul}$ & 0340 & 661.9 & 671.6 & 9.7 & 661.9 & 662.14 & 0.24 & 2 & 1 \\
\hline $71 R$ & $18 \mathrm{Jul}$ & 0500 & 671.6 & 681.3 & 9.7 & 671.6 & 672.86 & 1.26 & 13 & 1 \\
\hline $72 \mathrm{R}$ & $18 \mathrm{Jul}$ & 0620 & 681.3 & 691.0 & 9.7 & 681.3 & 681.96 & 0.66 & 7 & 1 \\
\hline $73 R$ & $18 \mathrm{Jul}$ & 0830 & 691.0 & 700.7 & 9.7 & 691.0 & 692.06 & 1.06 & 11 & 2 \\
\hline $74 R$ & $18 \mathrm{Jul}$ & 0950 & 700.7 & 710.4 & 9.7 & 700.7 & 701.58 & 0.88 & 9 & 1 \\
\hline $75 R$ & $18 \mathrm{Jul}$ & 1110 & 710.4 & 720.1 & 9.7 & 710.4 & 710.89 & 0.40 & 4 & 1 \\
\hline $76 \mathrm{R}$ & $18 \mathrm{Jul}$ & 1235 & 720.1 & 729.8 & 9.7 & 720.1 & 720.53 & 0.38 & 4 & 1 \\
\hline $77 \mathrm{R}$ & $18 \mathrm{Jul}$ & 1400 & 729.8 & 739.5 & 9.7 & 729.8 & 730.68 & 0.56 & 6 & 1 \\
\hline $78 \mathrm{R}$ & $18 \mathrm{Jul}$ & 1545 & 739.5 & 749.2 & 9.7 & 739.5 & 739.7 & 0.16 & 2 & 1 \\
\hline $79 R$ & $18 \mathrm{Jul}$ & 2145 & 749.2 & 758.9 & 9.7 & 749.2 & 749.48 & 0.28 & 3 & 1 \\
\hline $80 \mathrm{R}$ & $18 \mathrm{Jul}$ & 2255 & 758.9 & 768.6 & 9.7 & 758.9 & 768.02 & 9.12 & 94 & 7 \\
\hline $81 R$ & 19 Jul & 0015 & 768.6 & 778.3 & 9.7 & 768.6 & 769.93 & 1.33 & 14 & 2 \\
\hline $82 \mathrm{R}$ & 19 Jul & 0205 & 778.3 & 788.0 & 9.7 & 778.3 & 779.94 & 1.64 & 17 & 2 \\
\hline $83 R$ & 19 Jul & 0335 & 788.0 & 797.7 & 9.7 & 788.0 & 789.87 & 1.87 & 19 & 3 \\
\hline $84 \mathrm{R}$ & 19 Jul & 0505 & 797.7 & 807.4 & 9.7 & 797.7 & 798.77 & 1.07 & 11 & 1 \\
\hline $85 R$ & $19 \mathrm{Jul}$ & 0720 & 807.4 & 817.1 & 9.7 & 807.4 & 807.88 & 0.42 & 4 & 1 \\
\hline $86 \mathrm{R}$ & $19 \mathrm{Jul}$ & 0920 & 817.1 & 826.8 & 9.7 & 817.1 & 821.40 & 4.30 & 44 & 4 \\
\hline $87 \mathrm{R}$ & 19 Jul & 1055 & 826.8 & 836.5 & 9.7 & 826.8 & 832.89 & 6.09 & 63 & 5 \\
\hline $88 \mathrm{R}$ & 19 Jul & 1230 & 836.5 & 846.2 & 9.7 & 836.5 & 840.4 & 3.90 & 40 & 4 \\
\hline $89 \mathrm{R}$ & 19 Jul & 1425 & 846.2 & 855.9 & 9.7 & 846.2 & 847.18 & 0.98 & 10 & 1 \\
\hline $90 \mathrm{R}$ & $19 \mathrm{Jul}$ & 1625 & 855.9 & 865.6 & 9.7 & 855.9 & 857.65 & 1.75 & 18 & 2 \\
\hline $91 \mathrm{R}$ & 19 Jul & 1810 & 865.6 & 875.3 & 9.7 & 865.6 & 867.16 & 1.56 & 16 & 2 \\
\hline $92 \mathrm{R}$ & 19 Jul & 1955 & 875.3 & 885.0 & 9.7 & 875.3 & 878.90 & 3.60 & 37 & 4 \\
\hline $93 \mathrm{R}$ & 19 Jul & 2155 & 885.0 & 894.7 & 9.7 & 885.0 & 886.47 & 1.47 & 15 & 1 \\
\hline $94 \mathrm{R}$ & $20 \mathrm{Jul}$ & 0000 & 894.7 & 904.4 & 9.7 & 894.7 & 900.31 & 5.61 & 58 & 5 \\
\hline $95 \mathrm{R}$ & $20 \mathrm{Jul}$ & 0230 & 904.4 & 914.1 & 9.7 & 904.4 & 907.66 & 3.26 & 34 & 4 \\
\hline $96 \mathrm{R}$ & $20 \mathrm{Jul}$ & 0455 & 914.1 & 923.8 & 9.7 & 914.1 & 916.33 & 2.23 & 23 & 3 \\
\hline 97R & $20 \mathrm{Jul}$ & 0650 & 923.8 & 933.5 & 9.7 & 923.8 & 925.69 & 1.88 & 19 & 3 \\
\hline $98 \mathrm{R}$ & $20 \mathrm{Jul}$ & 0900 & 933.5 & 943.2 & 9.7 & 933.5 & 939.17 & 5.67 & 58 & 5 \\
\hline 99R & $20 \mathrm{Jul}$ & 1100 & 943.2 & 952.9 & 9.7 & 943.2 & 946.80 & 3.60 & 37 & 4 \\
\hline $100 R$ & $20 \mathrm{Jul}$ & 1245 & 952.9 & 962.6 & 9.7 & 952.9 & 953.75 & 0.85 & 9 & 1 \\
\hline $101 R$ & $20 \mathrm{Jul}$ & 1410 & 962.6 & 972.3 & 9.7 & 962.6 & 966.13 & 3.53 & 36 & 4 \\
\hline $102 \mathrm{R}$ & $20 \mathrm{Jul}$ & 1530 & 972.3 & 982.0 & 9.7 & 972.3 & 973.20 & 0.90 & 9 & 1 \\
\hline $103 \mathrm{R}$ & $20 \mathrm{Jul}$ & 1655 & 982.0 & 991.7 & 9.7 & 982.0 & 984.98 & 2.98 & 31 & 3 \\
\hline $104 \mathrm{R}$ & $20 \mathrm{Jul}$ & 1815 & 991.7 & 1001.4 & 9.7 & 991.7 & 992.13 & 0.43 & 4 & 1 \\
\hline $105 R$ & $20 \mathrm{Jul}$ & 1925 & 1001.4 & 1011.1 & 9.7 & 1001.4 & 1002.00 & 0.60 & 6 & 2 \\
\hline $106 \mathrm{R}$ & $20 \mathrm{Jul}$ & 2110 & 1011.1 & 1020.8 & 9.7 & 1011.1 & 1014.58 & 3.48 & 36 & 4 \\
\hline
\end{tabular}

$\mathrm{DSF}=$ drillers depth below seafloor, $\mathrm{CSF}=$ core depth below seafloor. $\mathrm{R}=$ rotary core barrel core 
Table T2. Summary of observed lithofacies, Site U1420. (Continued on next page.)

\begin{tabular}{|c|c|c|c|c|c|c|}
\hline Main facies & Subfacies & Facies & Description & Marine microfossils & Lithostratigraphic unit & $\begin{array}{l}\text { Tentative depositional } \\
\text { environment/diagenesis }\end{array}$ \\
\hline \multirow[t]{2}{*}{ Mud } & $\begin{array}{l}\text { Massive mud with } \\
\text { lonestones }\end{array}$ & F1a & $\begin{array}{l}\text { (Very) dark gray to dark greenish gray; } \\
\text { Facies thickness from } 3 \mathrm{~cm} \text { to } 3 \mathrm{~m} ; \\
\text { With dispersed to abundant clasts; } \\
\text { Bioturbation mostly absent, occasionally slight to heavy bioturbation; } \\
\text { Occasional shell fragments and foraminifers; } \\
\text { Subangular to subrounded lonestones, including sandstone, argillite, siltstone, } \\
\text { igneous rocks, granite, basalt, metasediment, greenstone, mudstone(?), } \\
\text { quartz, quartzite, rhyolite, gneiss, greywacke, vein quartz, and metaigneous; } \\
\text { Occasional occurrence of pods of sand and granules; } \\
\text { Occasional occurrence of mud laminae; } \\
\text { Inclined basal contact and wedge-shaped mud lamina and parallel/horizontal } \\
\text { clast orientation in Cores } 341 \text { - U1420A-92R and 93R; } \\
\text { Interbedded with Facies F1c, F4e, F4f, F5b, F5c, and F7 }\end{array}$ & Rare foraminifers & III & $\begin{array}{l}\text { Suspension fall-out, ice rafting, } \\
\text { or sediment gravity flows }\end{array}$ \\
\hline & $\begin{array}{l}\text { Massive mud } \\
\text { without lonestones }\end{array}$ & $\mathrm{F} 1 \mathrm{~b}$ & $\begin{array}{l}\text { Dark greenish gray to very dark gray; } \\
\text { Facies thickness from } 3 \mathrm{~cm} \text { to } 4.09 \mathrm{~m} ; \\
\text { Shell fragments present; } \\
\text { Mostly moderate to heavy bioturbation; } \\
\text { Interbedded with Facies F1a and F4f }\end{array}$ & $\begin{array}{l}\text { Rare diatoms and } \\
\text { foraminifers }\end{array}$ & III & $\begin{array}{l}\text { Suspension fall-out and } \\
\text { sediment gravity flows }\end{array}$ \\
\hline \multirow[t]{2}{*}{ Diamict } & Clast-poor diamict & $\mathrm{F} 4 \mathrm{e}$ & $\begin{array}{l}\text { (Very) dark gray; } \\
\text { Facies thickness from } 11 \mathrm{~cm} \text { to } 2.75 \mathrm{~m} \text {; } \\
\text { Mostly silty and sandy mud matrix; } \\
\text { Subrounded to subangular granule and pebble clasts, including argillite, basalt, } \\
\text { chert, conglomerate, gneiss, granite, mudstone, quartz, sandstone, siltstone, } \\
\text { quartz veins, arkosic sandstones, conglomerate, and greenstone; } \\
\text { Occasionally more muddy intervals and very thin mud beds; } \\
\text { Rare mud clasts and single sand laminae; } \\
\text { Some shell fragments; } \\
\text { Bioturbation absent; } \\
\text { Interbedded with Facies F1a, F4f, and F7 }\end{array}$ & Not documented & I, III & $\begin{array}{l}\text { Suspension setting, ice rafting } \\
\text { (mainly by icebergs) }\end{array}$ \\
\hline & Clast-rich diamict & $F 4 f$ & $\begin{array}{l}\text { Very dark gray; } \\
\text { Facies thickness from } 2 \mathrm{~cm} \text { to } 5.56 \mathrm{~m} \text {; } \\
\text { Mostly muddy occasionally silty and sandy matrix; } \\
\text { Subrounded to subangular granule and pebble clasts, including sandstone, } \\
\text { siltstone, granite, basalt, metasiltstone, greenstone, quartz, vein quartz, } \\
\text { rhyolite, mudstone, gneiss, argillite, greywacke, quartzite, gabbro, vesicular } \\
\text { basalt, shale, metasandstone, quartz-mica schist, diorite, mica-rich gneiss, } \\
\text { and pink feldspar; } \\
\text { One interval with preferred orientation; } \\
\text { Very rarely trace amounts of volcanic ash and shell fragments; } \\
\text { Bioturbation absent; } \\
\text { Interbedded with Facies F1a, F1c, F4e, and F5c }\end{array}$ & $\begin{array}{l}\text { Occasional } \\
\text { foraminifers }\end{array}$ & I, III & $\begin{array}{l}\text { Suspension setting, ice rafting } \\
\text { (mainly by icebergs) }\end{array}$ \\
\hline $\begin{array}{l}\text { Biosiliceous ooze; } \\
\text { biosiliceous-rich/ } \\
\text { bearing mud and/ } \\
\text { or sand; mud with } \\
\text { diatoms/biosilica }\end{array}$ & & $\mathrm{F} 5 \mathrm{~b}$ & $\begin{array}{l}\text { Dark greenish gray; } \\
\text { Facies thickness from } 42 \mathrm{~cm} \text { to } 1.4 \mathrm{~m} \text {; } \\
\text { Mud with dispersed clasts containing small traces of diatoms and sponge } \\
\text { spicules (based on smear slides from Samples } 341-\mathrm{U} 1420 \mathrm{~A}-59 \mathrm{R}-2 \mathrm{~A}, 90 \mathrm{~cm} \text {, } \\
\text { and 59R-3A, } 60 \mathrm{~cm} \text { ); } \\
\text { Occasionally with shell fragments; } \\
\text { Very rarely traces of volcanic ash; } \\
\text { Bioturbation absent or heavy; } \\
\text { Interbedded with Facies F1a }\end{array}$ & $\begin{array}{l}\text { Diatoms, sponge } \\
\text { spicules }\end{array}$ & III & $\begin{array}{l}\text { Temporarily increased } \\
\text { productivity and/or reduced } \\
\text { suspension settling and/or } \\
\text { better preservation }\end{array}$ \\
\hline
\end{tabular}


Table T2 (continued).

\begin{tabular}{|c|c|c|c|c|c|c|}
\hline Main facies & Subfacies & Facies & Description & Marine microfossils & Lithostratigraphic unit & $\begin{array}{l}\text { Tentative depositional } \\
\text { environment/diagenesis }\end{array}$ \\
\hline $\begin{array}{l}\text { Calcareous/ } \\
\text { carbonate- } \\
\text { bearing/rich mud, } \\
\text { silt, sand, diamict, } \\
\text { and/or diatom } \\
\text { ooze }\end{array}$ & & $\mathrm{F} 5 \mathrm{c}$ & $\begin{array}{l}\text { Very dark gray to dark greenish gray; } \\
\text { Facies thickness from } 42 \mathrm{~cm} \text { to } 2.81 \mathrm{~m} ; \\
\text { Foraminifers and shell fragments in muddy clast-rich diamict and mud; } \\
\text { One ostracod in sandy clast-rich diamict (smear slide from Sample } 341 \text { - } \\
\text { U1420A-71 R-1A, } 81 \mathrm{~cm} \text { ); } \\
\text { Rare gastropods in mud; } \\
\text { Bioturbation absent to heavy; } \\
\text { Interbedded with Facies F1a and F4f }\end{array}$ & $\begin{array}{l}\text { Foraminifers, } \\
\text { ostracod, } \\
\text { gastropod }\end{array}$ & I, IIII & $\begin{array}{l}\text { Temporarily increased } \\
\text { productivity and/or reduced } \\
\text { suspension settling and/or } \\
\text { better preservation }\end{array}$ \\
\hline $\begin{array}{l}\text { Volcaniclastic mud, } \\
\text { sand, diamict, } \\
\text { and/or ooze }\end{array}$ & & F7 & $\begin{array}{l}\text { Very dark gray to dark greenish gray; } \\
\text { Facies thickness from } 18 \mathrm{~cm} \text { to } 1.4 \mathrm{~m} ; \\
\text { In (sandy) clast-rich diamict and mud; } \\
\text { Interbedded with Facies F1a and F4e }\end{array}$ & Not documented & III & $\begin{array}{l}\text { Volcanic detritus either } \\
\text { bioturbated or reworked/ } \\
\text { redeposited by sediment } \\
\text { gravity flows }\end{array}$ \\
\hline
\end{tabular}


Table T3. Distribution of lithostratigraphic units and associated facies, Site U1420.

\begin{tabular}{lc}
\hline Lithostratigraphic units and associated facies & Hole U1420A \\
\hline Unit I & $0-58.2 \mathrm{~m} \mathrm{CSF-A} ;$ \\
F4e, F4f, F5c & Interval 1R-1, 0 cm, to 7R- \\
& CC, 0 cm \\
Unit II & $58.2-448.5 \mathrm{~m} \mathrm{CSF-A;}$ \\
Not classified; sediment mostly not recovered & Interval 7R-CC, 0 cm, to \\
& $48 \mathrm{R}-1,0 \mathrm{~cm}$ \\
Unit III & $448.5-1014.5 \mathrm{~m} \mathrm{CSF-A} ;$ \\
F1a, F1b, F4e, F4f, F5b, F5c, F7 & Interval $48 \mathrm{R}-1,0 \mathrm{~cm}$, to \\
& $106 \mathrm{R}-\mathrm{CC}, 20 \mathrm{~cm}$ \\
\hline
\end{tabular}

Table T4. XRD mineral composition, Site U1420.

\begin{tabular}{|c|c|c|c|c|c|c|c|c|c|}
\hline $\begin{array}{l}\text { Core, section, interval } \\
(\mathrm{cm})\end{array}$ & $\begin{array}{l}\text { Top depth } \\
\text { CSF-A (m) }\end{array}$ & $\begin{array}{l}\text { Mica } \\
\text { (counts) }\end{array}$ & $\begin{array}{l}\text { Hornblende } \\
\text { (counts) }\end{array}$ & $\begin{array}{l}\text { Chlorite + } \\
\text { kaolinite } \\
\text { (counts) }\end{array}$ & $\begin{array}{c}\text { Total clays } \\
\text { (counts) }\end{array}$ & $\begin{array}{c}\text { Quartz } \\
\text { (counts) }\end{array}$ & $\begin{array}{c}\text { Plagioclase } \\
\text { (counts) }\end{array}$ & $\begin{array}{l}\text { Calcite } \\
\text { (counts) }\end{array}$ & $\begin{array}{c}\text { Pyrite } \\
\text { (counts) }\end{array}$ \\
\hline \multicolumn{10}{|l|}{ 341-U1420A- } \\
\hline 2R-1W, 57-58 & 10.27 & 4,164 & 4,864 & 5,983 & 2,691 & 9,762 & 11,372 & 2,771 & 1,917 \\
\hline $4 \mathrm{R}-1 \mathrm{~W}, 13-14$ & 29.23 & 3,446 & 3,247 & 4,794 & 2,495 & 8,502 & 12,211 & 2,523 & 2,120 \\
\hline $5 \mathrm{R}-1 \mathrm{~W}, 32-33$ & 39.12 & 3,352 & 2,953 & 4,024 & 2,348 & 8,957 & 8,852 & 2,470 & 1,942 \\
\hline 50R-1W, 47-48 & 468.37 & 7,873 & 7,033 & 13,016 & 2,579 & 8,188 & 17,565 & 3,006 & 2,288 \\
\hline 51R-1W, 47-48 & 478.07 & 3,639 & 5,039 & 5,283 & 2,334 & 9,902 & 8,433 & 2,512 & 2,124 \\
\hline 59R-1W, 83-84 & 556.03 & 4,549 & 5,493 & 6,683 & 2,631 & 6,648 & 9,132 & 3,296 & 2,656 \\
\hline 59R-3W, 60-61 & 558.80 & 7,068 & 9,517 & 9,517 & 2,670 & 6,018 & 8,607 & 4,164 & 2,757 \\
\hline 63R-2W, 60-61 & 596.10 & 4,619 & 6,123 & 5,983 & 2,603 & 6,473 & 7,103 & 3,324 & 3,097 \\
\hline 64R-1W, 37-38 & 604.07 & 4,829 & 4,794 & 8,363 & 2,663 & 7,068 & 10,707 & 2,859 & 2,274 \\
\hline 65R-1W, 37-38 & 613.77 & 3,919 & 3,744 & 5,283 & 2,582 & 7,453 & 7,593 & 2,831 & 2,092 \\
\hline 66R-1W, 37-38 & 623.47 & 4,024 & 4,479 & 5,808 & 2,624 & 7,873 & 10,217 & 2,967 & 2,379 \\
\hline 68R-1W, 38-39 & 642.88 & 5,353 & 4,444 & 8,957 & 2,659 & 8,572 & 12,071 & 3,142 & 2,292 \\
\hline 69R-1W, 38-39 & 652.58 & 4,024 & 3,709 & 6,088 & 2,666 & 6,298 & 9,972 & 3,293 & 2,106 \\
\hline 71R-1W, 38-39 & 671.98 & 6,123 & 5,808 & 10,812 & 2,526 & 10,602 & 14,976 & 2,656 & 2,061 \\
\hline 72R-1W, 38-39 & 681.68 & 6,438 & 8,782 & 11,057 & 2,645 & 15,360 & 17,040 & 3,604 & NA \\
\hline 73R-1W, 38-39 & 691.38 & 4,164 & 3,989 & 7,908 & 2,561 & 11,477 & 8,817 & 2,659 & 2,050 \\
\hline 74R-1W, 38-39 & 701.08 & 4,129 & 4,514 & 7,803 & 2,404 & 8,957 & 9,167 & 3,198 & 2,505 \\
\hline 80R-1W, 38-39 & 759.28 & 6,963 & 9,692 & 9,447 & 2,670 & 5,878 & 8,223 & 2,981 & 3,499 \\
\hline $81 \mathrm{R}-1 \mathrm{~W}, 46-47$ & 769.06 & 5,004 & 4,339 & 8,887 & 2,677 & 8,433 & 7,838 & 3,209 & 2,218 \\
\hline $82 \mathrm{R}-1 \mathrm{~W}, 46-47$ & 778.76 & 4,689 & 4,199 & 7,943 & 2,799 & 7,418 & 20,959 & 2,614 & 2,239 \\
\hline 83R-1W, 32-33 & 788.32 & 4,969 & 5,808 & 6,788 & 2,768 & 5,563 & 5,948 & 3,814 & 3,023 \\
\hline 83R-2W, 9-10 & 789.12 & 3,814 & 3,604 & 5,878 & 2,736 & 6,998 & 9,937 & 2,488 & 2,372 \\
\hline $86 \mathrm{R}-2 \mathrm{~W}, 55-56$ & 819.15 & 3,814 & 3,488 & 5,808 & 2,561 & 7,628 & 6,403 & 2,796 & 2,071 \\
\hline $88 \mathrm{R}-1 \mathrm{~W}, 51-52$ & 837.01 & 4,199 & 6,368 & 6,893 & 2,635 & 6,263 & 8,328 & 3,146 & 2,806 \\
\hline 89R-1W, 51-52 & 846.71 & 4,164 & 3,779 & 6,613 & 2,666 & 9,412 & 10,882 & 2,845 & 2,085 \\
\hline $90 \mathrm{R}-1 \mathrm{~W}, 51-52$ & 856.41 & 4,164 & 3,814 & 6,298 & 2,701 & 6,858 & 8,677 & 3,418 & 2,428 \\
\hline 91R-1W, 51-52 & 866.11 & 4,864 & 4,269 & 8,398 & 2,789 & 8,258 & 10,812 & 4,129 & 2,117 \\
\hline 92R-1W, 51-52 & 875.81 & 4,409 & 6,228 & 7,243 & 2,887 & 6,438 & 6,823 & 3,404 & 2,638 \\
\hline 93R-1W, 51-52 & 885.51 & 4,514 & 4,094 & 7,523 & 2,670 & 8,782 & 13,401 & 3,041 & 2,106 \\
\hline $94 \mathrm{R}-1 \mathrm{~W}, 50-51$ & 895.20 & 4,584 & 4,409 & 7,943 & 2,607 & 6,998 & 12,631 & 2,936 & 2,278 \\
\hline 95R-1W, 60-61 & 905.00 & 5,773 & 4,234 & 9,587 & 2,631 & 11,547 & 13,751 & 3,223 & 2,141 \\
\hline 97R-1W, 70.5-71.5 & 924.51 & 6,368 & 5,703 & 11,617 & 2,729 & 9,412 & 14,171 & 2,957 & 2,176 \\
\hline $98 \mathrm{R}-4 \mathrm{~W}, 15-16$ & 938.15 & 9,307 & 12,281 & 11,722 & 2,729 & 6,613 & 10,952 & 4,164 & 2,733 \\
\hline 100R-1W, 33-34 & 953.23 & 4,444 & 3,534 & 7,033 & 2,684 & 10,532 & 14,276 & 3,030 & 2,134 \\
\hline 101R-1W, 50-51 & 963.10 & 3,989 & 3,919 & 6,753 & 2,544 & 9,202 & 9,342 & 2,677 & 2,036 \\
\hline 102R-1W, 50-51 & 972.80 & 4,619 & 0 & 8,328 & 2,414 & 8,013 & 20,224 & 3,674 & 1,917 \\
\hline 103R-1W, 50-51 & 982.50 & 4,479 & 4,024 & 8,048 & 2,446 & 10,987 & 17,460 & 2,813 & 2,278 \\
\hline 105R-1W, 43-44 & 1001.83 & 3,321 & 2,978 & 4,969 & 2,432 & 7,768 & 6,753 & 2,600 & 2,141 \\
\hline 106R-2W, 43-44 & 1012.94 & 4,234 & 4,129 & 6,823 & 2,334 & 11,337 & 9,342 & 2,652 & 1,924 \\
\hline
\end{tabular}

NA = not applicable

Table T5. Diatoms, Site U1420. This table is available in an oversized format. 
Table T6. Radiolarians, Site U1420.

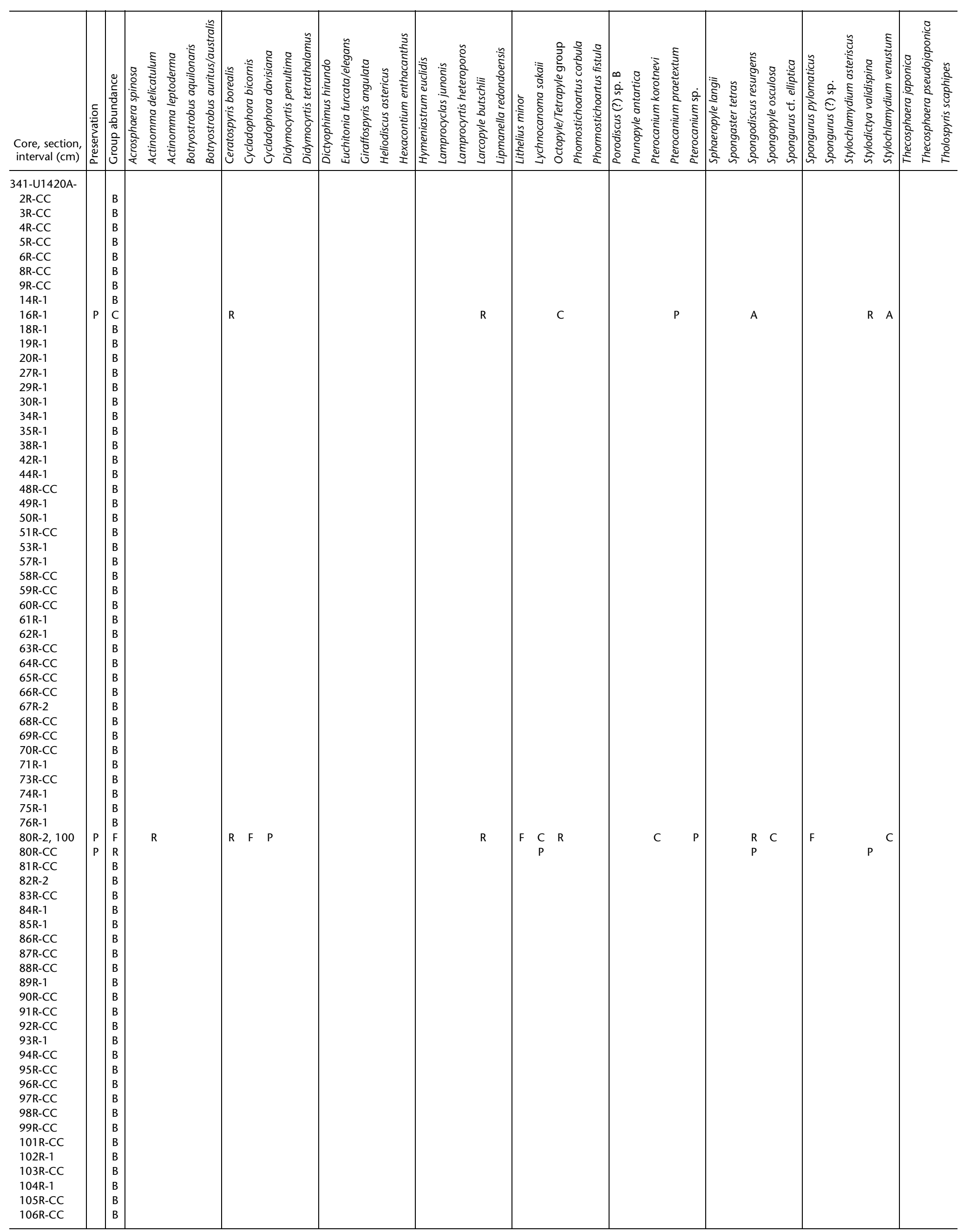

Preservation: $\mathrm{P}=$ poor. Abundance: $\mathrm{C}=$ common, $\mathrm{F}=$ few $\mathrm{R}=$ rare, $\mathrm{P}=$ present, $\mathrm{B}=$ barren. $\mathrm{LO}=$ last occurrence. This table is also available in. $\mathrm{CSV}$. 
Table T7. Planktonic foraminifers, Site U1420.

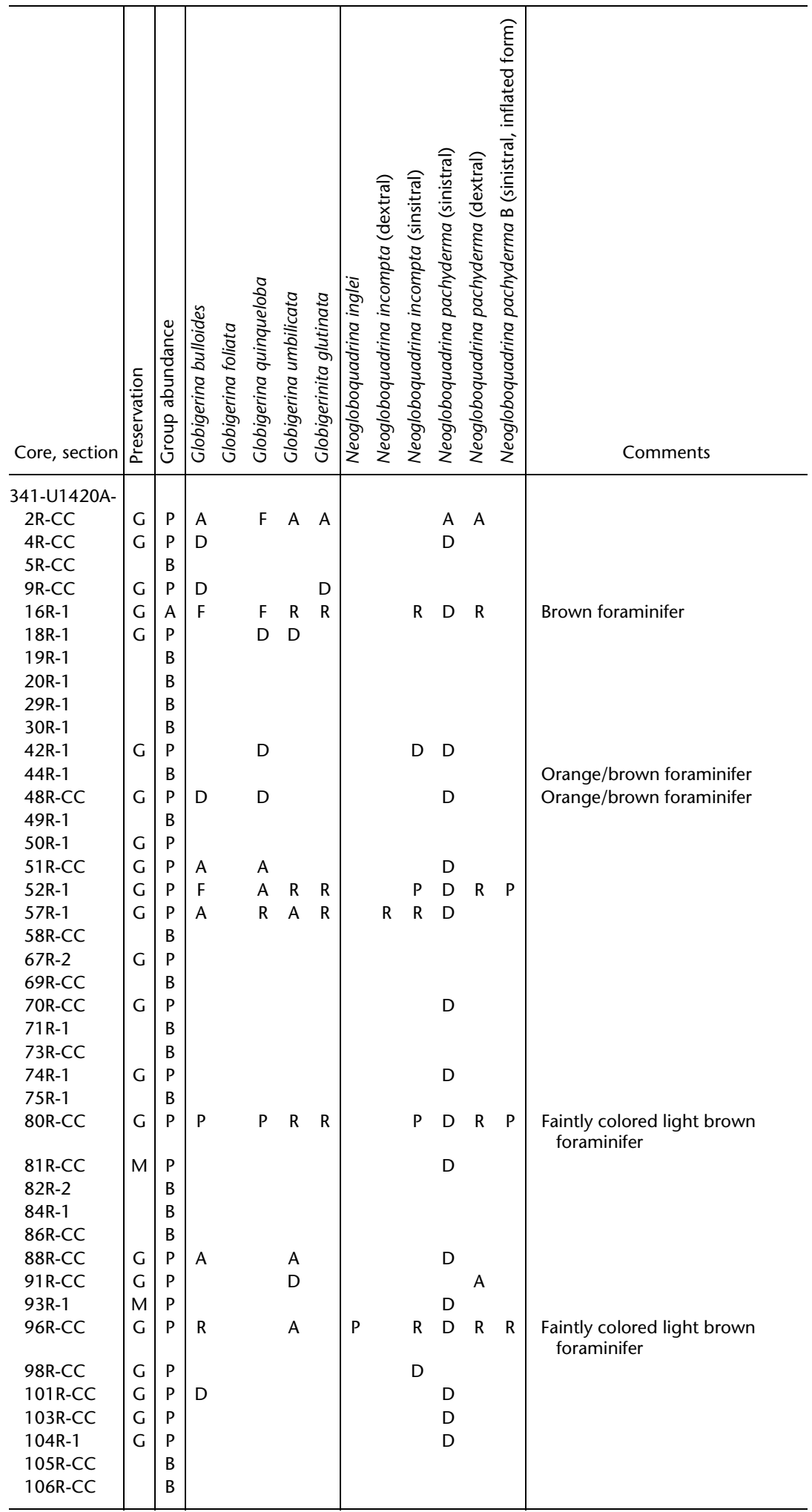

Preservation: $\mathrm{G}=$ good, $\mathrm{M}=$ moderate. Abundance: $\mathrm{D}=$ dominant, $\mathrm{A}=$ abundant, $\mathrm{F}=$ few, $\mathrm{R}=$ rare, $\mathrm{P}=$ present, $\mathrm{B}=$ barren. This table is also available in .CSV. 
Table T8. Benthic foraminifers, Site U1420. (Continued on next page.)

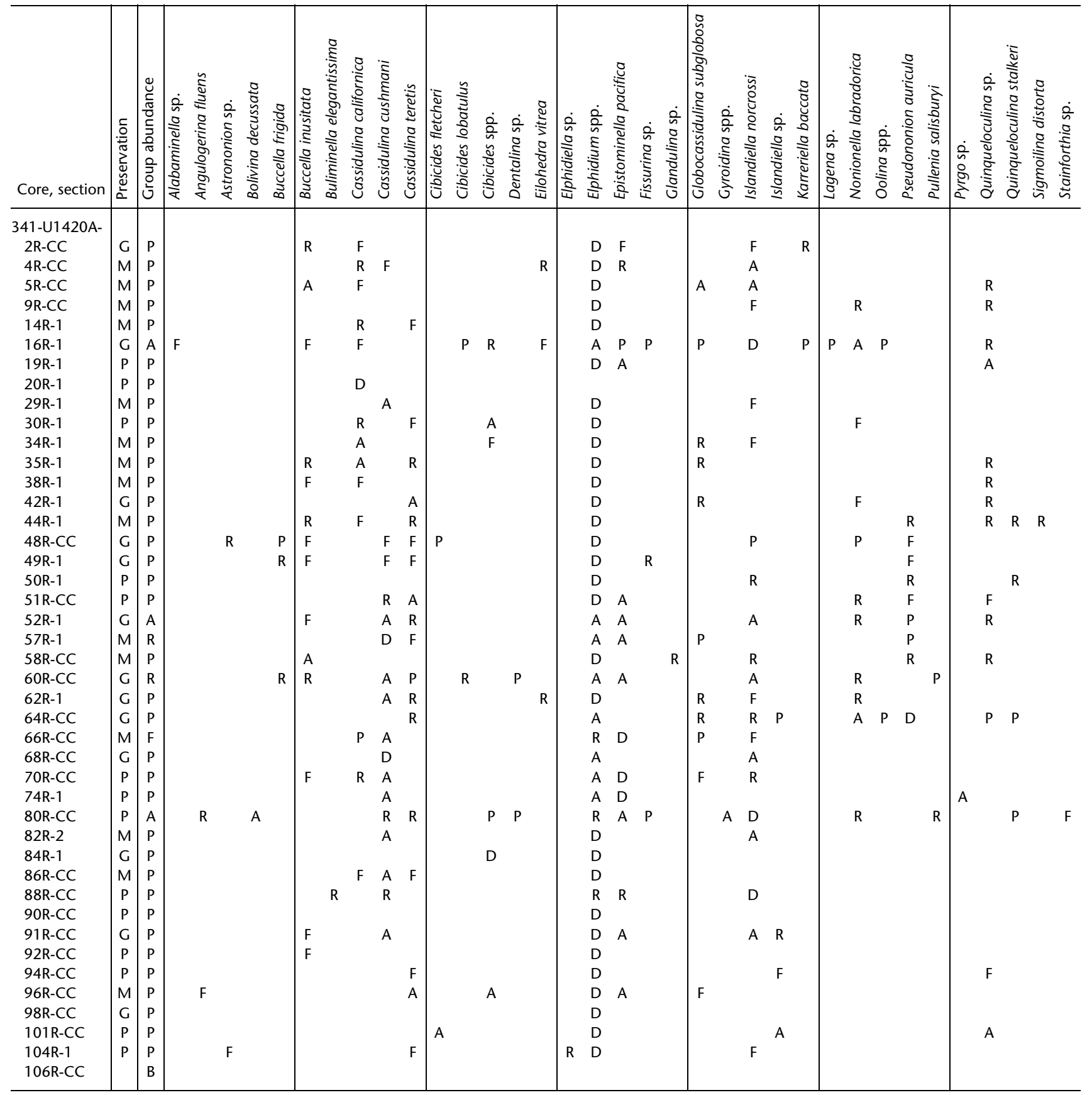

Preservation: $\mathrm{G}=$ good, $\mathrm{M}=$ moderate, $\mathrm{P}=$ poor. Abundance: $\mathrm{D}=$ dominant, $\mathrm{A}=$ abundant, $\mathrm{F}=$ few, $\mathrm{R}=$ rare, $\mathrm{P}=$ present, $\mathrm{B}=$ barren. This table is also available in .CSV. 
Table T8 (continued).

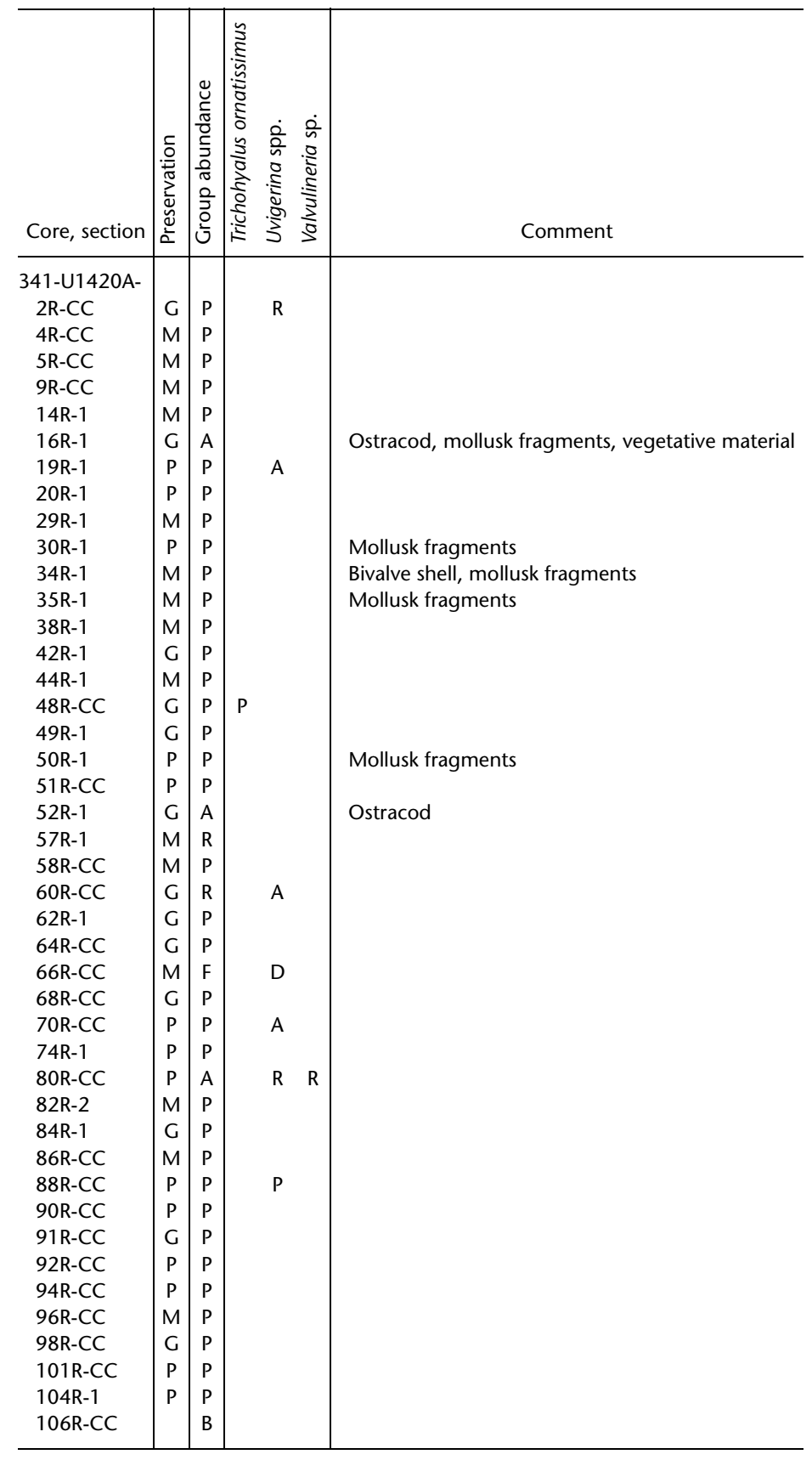

Table T9. Alternating field (AF) demagnetization steps and measurement interval used, Hole U1420A.

\begin{tabular}{ll}
\hline \multicolumn{1}{c}{ Cores undertaken } & AF demagnetization steps (mT) \\
\hline Sections 2R-1, 2R-2, 4R-1, 5R-1 & $0,10,20$ \\
Section 38R-1 & $0,5,10,15,20,25,30,35,40$ \\
Section 44R-1 & $0,5,10,15,20,25,30$ \\
All other cores & $0,5,10,15,20$ \\
\hline \multicolumn{1}{c}{ Cores undertaken } & \multicolumn{1}{c}{ Measurement interval (cm) } \\
\hline Sections 48R-1, 48R-2, 50R-1, 52R-1 & 1 \\
All other cores & 2.5 \\
\hline
\end{tabular}

